PNL-7660

UC-512

2F

\title{
Compilation of Data to Estimate Groundwater Migration Potential for Constituents in Active Liquid Discharges at the Hanford Site
}
L. L. Ames
R J. Serne

March 1991

Prepared for the U.S. Department of Energy under Contract DE-AC06-76RLO 1830

Pacific Northwest Laboratory Operated for the U.S. Department of Energy by Battelle Memorial Institute 


\title{
DISCLAIMER
}

This report was prepared as an account of work sponsored by an agency of the United States Government. Neither the United States Government nor any agency thereof, nor Battelle Memorial Institute, nor any of their employees, makes any warranty, expressed or implied, or assumes any legal liability or responsibility for the accuracy, completeness, or usefulness of any information, apparatus, product, or processdisclosed, or represents that its use would not infringe privately owned rights. Reference herein to any specific commercial product, process, or service by trade name, trademark, manufacturer, or otherwise does not necessarily constitute or imply its endorsement, recommendation, or favoring by the United States Government or any agency thereof, or Battelle Memorial Institute. The views and opinions of authors expressed herein do not necessarily state or reflect those of the United States Government or any agency thereof.

\author{
PACIFIC NORTHWEST LABORATORY \\ operatedby \\ BATTELLE MEMORIAL INSTITUTE \\ for the \\ UNITED STATES DEPARTMENT OF ENERGY \\ under Contract DE-AC06-76RLO 7830
}

Printed in the United States of America

Available to DOE and DOE contractors from the

Office of Scientific and Technical Information, P.O. Box 62, Oak Ridge, TN 37831; prices available from (615) 576-8401. FTS 626-8401.

Available to the public from the National Technical Information Service, U.S. Department of Commerce, 5285 Port Royal Rd., Springfield, VA 22161. 
COMPILATION OF DATA TO ESTIMATE GROUNDWATER MIGRATION POTENTIAL FOR CONSTITUENTS IN ACTIVE

LIQUID DISCHARGES AT THE HANFORD SITE

L. L. Ames

R. J. Serne

March 1991

Prepared for the U.S. Department of Energy under Contract DE-ACO6-76RLO 1830

Pacific Northwest Laboratory Richland, Washington 99352 


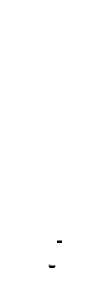




\section{EXECUTIVE SUMMARY}

A preliminary characterization of the constituents present in the 33 liquid waste streams at the U.S. Department of Energy's Hanford Site has been completed by Westinghouse Hanford Company. In addition, Westinghouse Hanford has summarized the soil characteristics based on drill logs collected at each site that receives these liquid wastes. Literature searches were conducted and available Hanford-specific data were tabulated and reviewed. General literature on organic chemicals present in the liquid waste streams was also reviewed. Specifically, values for water solubility, soil adsorption, sediment organic carbon adsorption properties, octanol-water partition coefficients $\left(K_{0} / w\right)$, Henry's Law constants (a measure of volatility), and biodegradation half-lives were gleaned from the literature to allow estimates of migration potential. Using all of this information, Pacific Northwest Laboratory has developed a best estimate of the transport characteristics (water solubility and soil adsorption properties) for those radionuclides and inorganic and organic chemicals identified in the various waste streams.

We assume that the potential for transport is qualified through the four geochemical parameters: solubility, distribution coefficient, persistence (radiogenic or biochemical half-life), and volatility. Summary tables of these parameters are presented for more than 50 inorganic and radioactive species and more than 50 organic compounds identified in the liquid waste streams. Brief descriptions of the chemical characteristics of Hanford sediments, solubility, and adsorption processes, and of how geochemical parameters are used to estimate migration in groundwater-sediment environments are also presented. Groundwater monitoring data are tabulated for wells neighboring the facilities that receive the liquid wastes.

The radioactive and organic constituents measured in groundwaters can be used to infer actual migration potentials for comparison with the literature assessments. In general the comparison is good. Compounds that appear to be mobile include methylene chloride, chloroform, bis(2-ethylhexyl) phthalate, acetone, methyl ethy 1 ketone, tetrachloroethylene, ${ }^{129} \mathrm{I},{ }^{60} \mathrm{Co},{ }^{106} \mathrm{Ru},{ }^{99} \mathrm{Tc}$, ${ }^{3} \mathrm{H},{ }^{137} \mathrm{Cs}$, and ${ }^{90} \mathrm{Sr}$. Bis(2-ethylhexy 1$)$ phthalate, ${ }^{137} \mathrm{Cs}$, and ${ }^{90} \mathrm{Sr}$ are not expected (based on their adsorption properties) to be mobile, but all of the 
other species identified are expected to be mobile. The report recommends data collection activity to gather important data on the solubility, adsorption, and degradation properties of the potentially mobile species identified. 


\section{ACKNOWLEDGMENTS}

The study was funded by the Environmental Technology Group of Westinghouse Hanford Company. The authors wish to thank J. W. Cammann and J. C. Sonnichsen of the Environmental Technology Group for their support.

We wish to thank S. R. Peterson, ICF Northwest Company, for providing access to the Soil Transport Fate computerized database, and N. G. Carter, Pacific Northwest Laboratory, for performing computer searches and alerting us to the existence of the Syracuse University-supported databases on chemical fate and biological degradation. We wish to acknowledge the help of W. J. Martin and L. J. Criscenti in accessing these computer databases.

Finally we wish to thank J. A. Schramke for preparing the organic structures shown in the document using the software package Chembase and E. A. Fairweather for typing the manuscript and collating the sections into a cohesive document. 

EXECUTIVE SUMMARY .................. i ACKNOWLEDGMENTS ......................... v

1.0 INTRODUCTION . . . . . . . . . . . . . . . . . . . 1.1

2.0 DESCRIPTION OF WASTE STREAMS . . . . . . . . . . 2.1

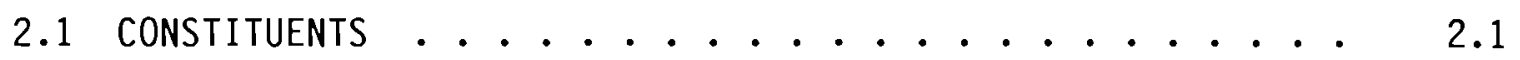

2.1 .1 Inorganics ................. 2.1

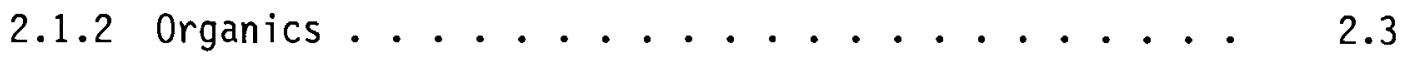

2.1 .3 Radionuclides ........................ 2.11

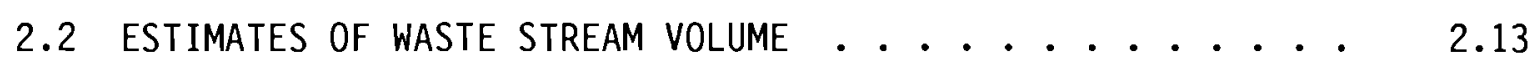

3.0 CHARACTERISTICS OF HANFORD SEDIMENTS ............... 3.1

4.0 SEDIMENT INTERACTIONS . . . . . . . . . . . . 4.1

4.1 CONSTANT DISTRIBUTION COEFFICIENT . . . . . . . 4.2

4.2 INTRODUCTION TO ESTIMATING ADSORPTION CONSTANTS . . . . 4.5

4.3 DISTRIBUTION COEFFICIENTS FOR INORGANICS AND $\ldots \ldots \ldots \ldots$
RADIONUCLIDES . . . . . . . . . . . . . . . . . . 4.9

4.4 SOLUBILITY OF INORGANIC AND RADIONUCLIDE CONSTITUTENTS $\ldots 4.25$

4.5 CHEMICAL/RADIOLOGICAL HALF-LIVES . . . . . . . . . 4.29

4.6 DISTRIBUTION COEFFICIENTS FOR ORGANICS . . . . . 4.32

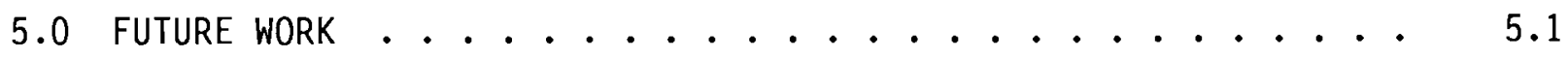

6.0 REFERENCES ................................. 6.1

APPENDIX A - ENVIRONMENTAL FATE OF ORGANIC ANALYTES REPORTED IN THE

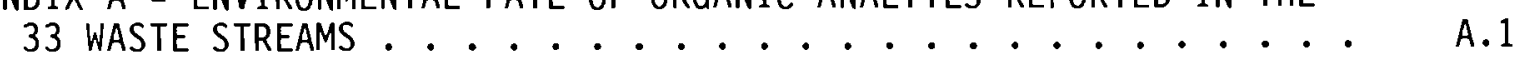

APPENDIX B - EXAMPLES OF HANFORD SEDIMENT COLUMN LEAKAGE OF ORGANIC COMPOUNDS AND RADIONUCLIDES $\ldots \ldots$ 


\section{FIGURES}

1 Classification of Waste Streams Based on Five Key Parameters of Acidity, Radioactivity, Organic Content, Dissolved Solids Content, and Waste Stream Volume . . . . . . . . . . 4.6

$2 \quad R_{d}$ Estimates for Beryllium, Calcium, and Magnesium . . . . . . 4.10

$3 \mathrm{R}_{\mathrm{d}}$ Estimates for Strontium and Barium . . . . . . . . . . 4.11

$4 \quad R_{d}$ Estimates for Lithium, Potassium, Sodium, and Ammonium ............................... 42

$5 \quad \mathrm{R}_{\mathrm{d}}$ Estimates for Cobalt, Iron, and Manganese . . . . . . . . 4.13

$6 R_{d}$ Estimates for Lead, Zinc, Cadmium, Copper, Nickel, Silver, and Mercury ................ . . 4.14

$7 \quad R_{d}$ Estimates for Antimony, Molybdenum, and Sulfide . . . . . . 4.15

$8 \mathrm{R}_{\mathrm{d}}$ Estimates for Zirconium, Niobium, and Tin . . . . . . . . 4.16

$9 \quad R_{d}$ Estimates for Chromium(VI), Tritium, Technetium, Chloride, Fluoride, Iodine, Sulfate, Nitrate, Xenon, Krypton, and Argon . . . . . . . . . . . . . . . . 4.17

$10 \mathrm{R}_{\mathrm{d}}$ Estimates for Cesium . . . . . . . . . . . . . 4.18

$11 R_{d}$ Estimates for Chromium(III), Rare Earths, Americium, and Curium ............................. 49

$12 \mathrm{R}_{\mathrm{d}}$ Estimates for Plutonium . . . . . . . . . . . . . 4.20

$13 \mathrm{R}_{\mathrm{d}}$ Estimates for Neptunium and Uranium . . . . . . . . . 4.21

$14 \mathrm{R}_{\mathrm{d}}$ Estimates for Aluminum, Silicon, and Titanium . . . . . . 4.22

$15 \mathrm{R}_{\mathrm{d}}$ Estimates for Phosphate and Vanadium . . . . . . . . . . . 4.23

$16 \mathrm{R}_{\mathrm{d}}$ Estimates for Ruthenium . . . . . . . . . . . . . 4.24 


\section{$\underline{\text { TABLES }}$}

1 The 33 Liquid Effluent Streams and the Facilities Receiving the

Streams..................... . . . . 1.2

2 Inorganic Analyte Reporting Frequency for the Waste

Stream Analyses.................... . . 2.2

3 Waste Stream Inorganic Analyte Content and Mean Field pH Based on Reported Data .................... 2.4

4 Discharge Rate of Principal Inorganic Analytes . . . . . . . 2.5

5 Analytical Frequency for the Organic Analytes . . . . . . . 2.6

6 Classifications of Some Hazardous Chemicals Found in the 33 Waste Streams................. 2.8

7 Waste Streams Containing the Largest Contents of Organic Analytes .........................

8 Daily Discharge Amounts of Organic Analytes Based on Analyses and Effluent Volumes of the 33 Waste Streams . . . . . . . 2.10

9 Organic Analytes Reported in Three 200 West Area Wellwater Samples........................ 2.11

10 Frequency of Radionuclides in the 33 Waste Streams . . . . . 2.12

11 Waste Streams with the Bulk of the Total Radioactivity in the 33 Waste Streams . . . . . . . . . . . . . 2.13

12 Waste Stream Volume Estimates . . . . . . . . . . . . . 2.14

13. Recent Sediment Data That Include Organic Carbon Values . . . 3.2

14 Waste Stream Identification . . . . . . . . . . . . 4.7

15 Qualitative Estimate of Mineral Solubility of Hanford
Sediment in Pore Water . . . . . . . . . . . . . 4.28

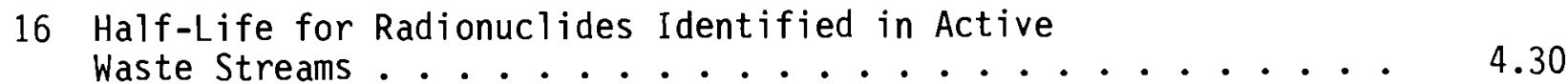

17 Radionuclides with Half-Lives Long Enough for Environmental Concern ................. 4.31

18 Physical and Chemical Processes Used to Assess the Distribution and Fate of Organic Compounds . . . . . . . . . . . . . 
19 Physicochemical Parameters Used in Evaluation of Transport Properties of Organic Compounds . . . . . . . . . . 4.34

20 Environmental Processes Affecting the Organic Compounds Identified in the 33 Waste Streams . . . . . . . . 4.35

21 Regression Equations Useful for Estimation of Partition

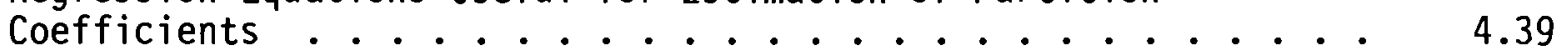

22 Available Physicochemical Data for the Organic Compounds Listed in Table 5...................... 4.42

23 Qualitative Ranking of Geochemical Attributes of the Organic Compounds Listed in Table $5 \ldots \ldots$ 


\section{$1.0 \quad$ INTRODUCTION}

Operating facilities at the Hanford Site in Washington State have historically discharged large quantities of liquid effluent, the bulk of which did not routinely contain radioactive materials, into the sediments. Because the radionuclide contents of the waste streams were generally low, this technique of disposal was chosen after consideration of the sediment column's cation exchange capacity characteristics, unsaturated sediment column depth, and groundwater migration rates.

The U.S. Department of Energy, Richland Operations Office (DOE-RL) established a policy in 1984 to eliminate discharges of contaminated liquid to the sediment column and to meet all applicable federal and state environmental regulations. A plan and schedule were prepared in response to a request by Congress for discontinuation of the disposal of contaminated solutions into the sediment column.

At the request of the Washington State Department of Ecology (Ecology) and the U.S. Environmental Protection Agency (EPA), DOE-RL has initiated a study by its contractors, Westinghouse Hanford Company and Pacific Northwest Laboratory (PNL), (a) of the characteristics of liquid discharges at the Hanford Site. This report addresses in some detail the 33 waste streams identified in the Waste Stream Characterization Report (Westinghouse Hanford 1989) to provide a best estimate of the waste stream constitutents' potential for migration. In this report, the potential for transport is assumed to be quantified by three geochemical parameters: water solubility, adsorption distribution coefficient, and persistence (radiogenic or biochemical half-life). The 33 waste streams and their respective disposal units are listed in Table 1. Seven of the waste streams go to the same facility (216-B-3 pond system), and three go to double-shell tanks for interim storage.

(a) PNL is operated for DOE by Battelle Memorial Institute. 
TABLE 1. The 33 Liquid Effluent Streams and the Facilities
Receiving the Streams (Westinghouse Hanford 1989)

\section{Effluent Strean}

B Plant process condensate

PUREX Plant anmonia scrubber condensate

241-AY, 241- $A Z$ stean condensate

N Reactor effluent

PUREX Plant process condensate

$\mathrm{UO}_{3} \mathrm{Plant}$ process condensate

Plutonium Finishing $\mathrm{Plant}$ wastewater

PUREX Plant chemical sewer

B Plant chemical sewer

222-S Laboratory wastewater

2101-M Laboratory wastewater

209-E Laboratory wastewater

$T$ Plant wastewater

300 Area process wastewater

183-D Filter backf I ush wastewater

$B$ Plant stean condensate

PUREX Plant stean condensate

$S$ Plant wastewater

242-A Evaporator stean condensate

242-A Evaporator process condensate

2724-N Laundry wastewater

163-N Demineral ized wastewater

$\mathrm{UO}_{3}$ Plant wastewater

$B$ lant cooling water

PUREX Plant cooling water

$\mathrm{T}$ Plant laboratory wastewater

241-A Tank Farn cooling water

242-A Evaporator cooling water

242-S Evaporator stean condensate

244-AR Vault cooling water

284-E Powerplant cooling water

284-W Powerplant cooling water

400 Area secondary cooling water $(g)$

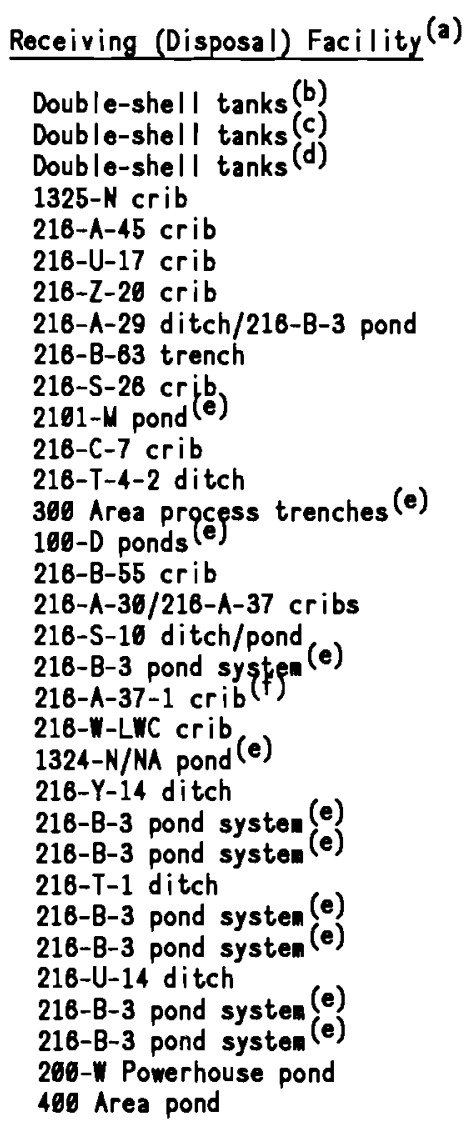

(a) Disposition as of September 1989.

(b) Discharged to 216-B-62 crib until January 1986. Currently discharged to double-shell tanks; will be rerouted to 216-B-62.

(c) Discharged to 216-A-36-B crib unit Septenber 1987. Currently discharged to double-shell tanks.

(d) Discharged to 216-A-8 crib until 1983. Currently discharged to double-shell tanks. Resumption of discharge to $216-A-8$ is pending review by Westinghouse Hanford and approval by DOE-RL.

(e) Resource Conservation and Recovery Act of 1978 (RCRA) disposal unit.

(f) Current discharge has been suspended; studies are under way to identify a future disposal site.

(g) 400 Area secondary cooling water is not related to Fast Flux Test Facility reactor heat renoval. 


\subsection{DESCRIPTION OF WASTE STREAMS}

The waste streams contain dissolved inorganics, organics, and radionuclides, as well as suspended solids. Because the chemical composition of the waste streams (e.g., the pH and types and amounts of dissolved salts) influences the solubility and adsorption properties of radionuclides and regulated chemicals, a discussion of the overall chemical nature of the waste streams is provided here. Each of these constituents will be discussed for the 33 streams for which data are available. The waste stream samples used for chemical analyses were collected over short time intervals and therefore may not be representative of overall chemical compositions for the life of the waste stream. The same can be said for the stream volumes given in this report, because the waste stream volumes were taken over a short time interval and the streams often fluctuate widely in volume.

\subsection{CONSTITUENTS}

\section{1 .1 Inorganics}

A total of 33 inorganic constituents make up the bulk of the inorganic materials (not including radionuclides) that have been measured in the waste streams. These are listed in Table 2 in terms of analytical reporting frequency, N. Uranium, which is classifiable as either a radionuclide or a heavy metal, was the most frequently reported analyte, followed by sodium, calcium, and potassium. Magnesium and zinc are also commonly reported in these chemical analyses.

Average inorganic chemical analyses have been published for each waste stream (Westinghouse Hanford 1989). The averaged analyses were used to determine total waste stream inorganic content, by converting the average cation concentration to molarities and summing them. This treatment assumes that anions are present to maintain an electrostatic balance, but it is not a material-balancing procedure. Using the inorganic cation analysis averages presented by Westinghouse Hanford (1989) often conceals the considerable range in the individual analyses making up the average. For example, the analytical sodium content of B Plant chemical sewage varies from 4 to $6,000 \mathrm{mg} / \mathrm{L}$ for 
TABLE 2. Inorganic Analyte Reporting Frequency (N) for the Waste Stream Analyses (Westinghouse Hanford 1989)

\begin{tabular}{|c|c|c|c|}
\hline Analyte & $N$ & Analyte & $\mathrm{N}$ \\
\hline Uranium & 314 & Mercury & 97 \\
\hline Sodium & 310 & Silicon & 74 \\
\hline Calcium & 307 & Lead & 61 \\
\hline Potassium & 300 & Nickel & 43 \\
\hline Zinc & 285 & Cadmium & 39 \\
\hline Magnesium & 281 & Chromium & 38 \\
\hline Sulfate & 277 & Vanadium & 33 \\
\hline Barium & 265 & Phosphate & 24 \\
\hline Chloride & 250 & Sulfide & 16 \\
\hline Iron & 227 & Beryllium & 5 \\
\hline Fluoride & 178 & Silver & 4 \\
\hline Manganese & 171 & Lithium & 2 \\
\hline Copper & 155 & Arsenic & 1 \\
\hline Nitrate & 146 & Antimony & 1 \\
\hline Strontium & 136 & Tin & 1 \\
\hline Aluminum & 128 & Titanium & 1 \\
\hline Ammonium & 124 & & \\
\hline
\end{tabular}


individual analyses. It is doubtful that the sampling period was long enough or the number of individual analyses large enough to obtain a representative sample average.

Of more interest to determining environmental fate is the total waste stream content of inorganics, as shown in Table 3 . For comparison, the analyte contents of Hanford groundwater and Columbia River waters range from $7 \times 10^{-3}$ to $1 \times 10^{-3} \mathrm{M}$. Most of the waste streams are more dilute than these natural waters. The wastewaters from power plants were among the highest in total dissolved inorganics. Only three of the waste streams show average field $\mathrm{pH}$ values less than $\mathrm{pH} 6.0$, and even these three have $\mathrm{pH}$ values at or above 5.2. The overall inorganic analyte discharge rates $(\mathrm{kg} / \mathrm{mo})$ are given in Table 4. The amounts of $\mathrm{Ca}, \mathrm{Mg}, \mathrm{SO}_{4}, \mathrm{HCO}_{3}, \mathrm{~K}$, and $\mathrm{NH}_{4}$ discharged each month exceed or approach $5,000 \mathrm{~kg}$, and $\mathrm{NO}_{3}$ exceeds five times that amount. There are several known inorganic carcinogens and/or toxic substances in this list, including beryllium, cadmium, lead, silver, and mercury. The allowable limits for these constituents have been given by Ecology (1987). If these toxic metals were homogeneously distributed in the water discharged each month, concentrations would be below the maximum permissible limits and in the range 0.01 to $3 \mu \mathrm{g} / \mathrm{L}$, depending on the metal. The chemical analyses do not, however, indicate how these metals are distributed or their forms in the wastes.

\section{1 .2 Organics}

There are 51 organic constituents that were identified at least twice in analyses of the 33 waste streams. These are listed with their frequencies in Table 5. These 51 organic constituents are classified by structure group in Appendix A. Along with the structure, the data pertaining to soil sorption, solubility, and volatility are given for most of the organic constituents. Chloroform was the most prevalent organic analyte, even though it is not used in any of the chemical processes at the Hanford Site (Jungfleisch 1988). The chlorination of natural waters has been shown to commonly produce chloroform as well as other halogenated hydrocarbons (Dowty et al. 1975; Rook 1977; Larson and Rockwell 1979; Norwood et al. 1980). Chloroform and the phthalates 
TABLE 3. Waste Stream Inorganic Analyte Content and Mean Field pH Based on Reported Data (Westinghouse Hanford 1989)

Waste Stream

N Reactor effluent

163-N Demineralizer wastewater

183-D Filter backflush wastewater

PUREX Plant chemical sewer

PUREX Plant process condensate

PUREX Plant ammonia scrubber condensate

PUREX Plant stream condensate

PUREX Plant cooling water

B Plant chemical sewer

B Plant process condensate

B Plant steam condensate

B Plant cooling water

Plutonium Finishing Plant wastewater

$S$ Plant wastewater

$T$ Plant headend wastewater

$T$ Plant wastewater

$\mathrm{UO}_{3} \mathrm{Plant}$ process condensate

$\mathrm{UO}_{3} / \mathrm{U}$ Plants wastewater

241-A Tank Farm cooling water

241-AY, 241-AZ Tank Farms steam condensate

242-A Evaporator process condensate

242-A Evaporator steam condensate

242-A Evaporator cooling water

242-S Evaporator steam condensate

244-AR Vault cooling water

209-E Laboratory reflector water

222-S Laboratory wastewater

2101-M Laboratory wastewater

2724-W Laundry wastewater

284-E Powerplant wastewater

284-W Powerplant wastewater

300 Area process wastewater

400 Area secondary cooling water
Total

Inorganics, $\underline{M}$ Field $\mathrm{pH}$

$2.98 \times 10^{-4}$

$1.27 \times 10^{-2}$

$6.09 \times 10^{-3}$

$5.74 \times 10^{-3}$

$2.39 \times 10^{-3}$

$2.05 \times 10^{-2}$

$6.20 \times 10^{-4}$

$8.29 \times 10^{-4}$

$1.07 \times 10^{-1}$

$1.57 \times 10^{-4}$

$2.70 \times 10^{-5}$

$7.71 \times 10^{-4}$

$1.05 \times 10^{-3}$

$7.40 \times 10^{-4}$

$3.68 \times 10^{-4}$

$7.11 \times 10^{-4}$

$1.58 \times 10^{-1}$

$7.39 \times 10^{-4}$

$8.65 \times 10^{-4}$

$3.99 \times 10^{-5}$

$2.09 \times 10^{-2}$

$4.15 \times 10^{-4}$

$7.76 \times 10^{-4}$

$7.71 \times 10^{-4}$

$7.80 \times 10^{-4}$

$8.01 \times 10^{-4}$

$7.27 \times 10^{-4}$

$5.71 \times 10^{-4}$

$6.55 \times 10^{-3}$

$5.43 \times 10^{-1}$

1.52

$8.93 \times 10^{-4}$

$6.74 \times 10^{-3}$
7.8

6.1

6.3

6.2

6.6

9.3

6.1

6.7

7.4

8.2

6.3

6.8

6.4

6.6

6.8

6.3

5.8

6.6

6.4

5.2

10.4

6.1

6.2

5.7

6.8

7.3

6.3

6.2

9.1

8.3

8.2

6.0

8.0 
TABLE 4. Discharge Rate of Principal Inorganic Analytes (Jungfleisch 1988)

\begin{tabular}{|c|c|}
\hline Inorganic Analyte & $\begin{array}{c}\text { Discharge Rate } \\
\mathrm{kg} / \mathrm{mo}\end{array}$ \\
\hline Aluminum sulfate & 10,866 \\
\hline Ammonium nitrate & \\
\hline Ammonium bicarbonate & $5,896.8$ \\
\hline Ammonium hydroxide & 4.128 \\
\hline Barium sulfate & 140.6 \\
\hline Beryllium sulfate & 95.26 \\
\hline Cadmium sulfate & 0.313 \\
\hline Calcium nitrate & 185,976 \\
\hline $\begin{array}{l}\text { Calcjum bicarbonate } \\
\text { Calcium sulfate }\end{array}$ & 15,422 \\
\hline $\begin{array}{l}\text { Calcium sulfate } \\
\text { Sodium chromate }\end{array}$ & 19,051 \\
\hline $\begin{array}{l}\text { Sodium chromate } \\
\text { Copper sulfate }\end{array}$ & 1.225 \\
\hline $\begin{array}{l}\text { Copper sulfate } \\
\text { Ferrous sulfate }\end{array}$ & 331.13 \\
\hline Ferrous sulfate & $2,948.4$ \\
\hline Lead sulfate & 21.773 \\
\hline Magnesium nitrate & 68,040 \\
\hline Magnesium bicarbonate & $5,443.2$ \\
\hline Manganese sulfate & 226.8 \\
\hline Mercury sulfate & 0.077 \\
\hline Nickel sulfate & 0.907 \\
\hline Potassium sulfate & $6,804.0$ \\
\hline Silver sulfate & 5.897 \\
\hline Sodium bicarbonate & $4,399.9$ \\
\hline Strontium chloride & 3.992 \\
\hline Uranyl nitrate & 11.34 \\
\hline Vanadyl sulfate & 3.72 \\
\hline Zinc sulfate & 263.09 \\
\hline Sodium chloride & $5,896.8$ \\
\hline Sodium cyanide & 0.0953 \\
\hline Sodium fluoride & 412.78 \\
\hline Sodium nitrate & 771.12 \\
\hline Sodium phosphate monobasic & 362.88 \\
\hline Sodium phosphate dibasic & $1,088.6$ \\
\hline $\begin{array}{l}\text { Sodium bisulfide } \\
\text { Sodium sulfate }\end{array}$ & $\begin{array}{l}385.56 \\
14,061\end{array}$ \\
\hline
\end{tabular}


TABLE 5. Analytical Frequency (N) for the Organic Analytes (Westinghouse Hanford 1989)

\begin{tabular}{lr}
\multicolumn{1}{c}{ Organic Analyte } & N \\
\cline { 2 - 2 } Chloroform & 153 \\
Acetone & 97 \\
Butyl alcohol & 44 \\
Tributyl phosphate & 39 \\
Methyl ethyl ketone & 35 \\
Tridecane & 31 \\
2-butoxyethanol & 30 \\
Tetradecane & 30 \\
Tetrahydrofuran & 26 \\
Butoxyglycol & 21 \\
Methyl-n-butyl ketone & 19 \\
Butyraldehyde & 17 \\
Bis (2-ethylhexyl) phthalate & 16 \\
Benzyl alcohol & 13 \\
2-propanol & 12 \\
MIBK (hexone) & 11 \\
Dodecane & 9 \\
Methylene chloride & 9 \\
Methyl n-propyl ketone & 8 \\
Butyl nitrate & 7 \\
Methyl nitrate & 6 \\
Pentadecane & 6 \\
Phenol & 6 \\
N-methoxymethanamine & 5 \\
Ethoxytriethylene glycol & 4 \\
Benzoic acid & 3
\end{tabular}

\begin{tabular}{ll}
\multicolumn{1}{c}{ Organic Analyte } & N \\
\cline { 2 - 2 } 3,5-dimethylpyridine & 3 \\
Ethyl alcohol & 3 \\
Heptadecane & 3 \\
Hexadecane & 3 \\
Hexadecanoic acid & 3 \\
Methyl formate & 3 \\
Acetophenone & 2 \\
Benzaldehyde & 2 \\
Butoxydiglycol & 2 \\
Butylbenzyl phthalate & 2 \\
Decane & 2 \\
Di-n-butyl phthalate & 2 \\
Dichlorofluoromethane & 2 \\
Dimethoxymethane & 2 \\
Dimethylnitrosoamine & 2 \\
Di-n-octyl phthalate & 2 \\
Methoxydiglycol & 2 \\
Methoxytriglycol & 2 \\
2-methylnonane & 2 \\
2-methyl-5-propylnonane & 2 \\
Morpholine & 2 \\
Pelargic acid & 2 \\
Phenanthrene & 2 \\
Tetrachloroethylene & 2 \\
Undecane & 2
\end{tabular}


are of concern because they are carcinogens (Ecology 1987). Table 6 lists those compounds designated as acutely and moderately toxic by Ecology that were identified in the 33 active waste streams.

The waste streams containing the highest concentrations of organic analytes are listed in Table 7. The PUREX Process Condensate stream contains the highest concentration of organics.

Discharge rates for several organic constituents within the 33 waste streams are shown in Table 8. Tributyl phosphate and aliphatic hydrocarbons were present in the largest quantities, and tetrachloroethylene and chloroform were also high in ranking.

In addition to the organic analyte content of the 33 waste streams that is listed in Table 5, there is a considerable volume of data on organic compounds found in groundwaters taken from wells associated with the waste stream disposal sites. For example, Table 9 gives the analytical data on three 200 West Area wellwater samples. A large amount of wellwater sample analytical data were reported by Westinghouse Hanford (1989) as being associated with the ground disposal of the 33 waste streams. These data show that little degradation or sediment sorption is occurring for many of the organic constituents of the waste. Many of the organics in effluent streams were used to extract uranium and plutonium from spent fuel. The origins, uses, and degradation sequences of the uranium and plutonium extractants, the solvents, and their degradation products are discussed in detail by Burr (1958), Lane $(1960,1963)$, Dennis and West (1961), Blake et al. (1963), Huggard and Warner (1963), Gaumann et al. (1972), and Nowak (1971).

Several characteristics of the organic compounds found in the waste streams relating to migration are given in detail, with references, in Appendix A. 
TABLE 6. Classifications of Some Hazardous Chemicals Found in the 33 Waste Streams (Ecology 1987; Jungfleisch 1988)

Persistent Substance

Chloroform

Methylene chloride

Pentachlorophenol

Positive Carcinogen

Beryllium sulfate

Cadmium sulfate

Lead sulfate

Bis(2-ethylhexy1) phthalate

Chloroform

Ignitable Substance

Sodium bisulfide

Acetone

Benzyl alcohol

2-butoxyethanol

Butyl alcohol

Dodecane

Isopropyl alcohol (2-propanol)

Phenol

Pyridine

Tetradecane

Tetrahydrofuran

Reactive Substance

Sodium cyanide

Sodium bisulfide

Toxic Contaminant

Barium

Cadmium

Chromium

Lead

Mercury

Silver 
TABLE 7. Waste Streams Containing the Largest Contents of Organic Analytes (Westinghouse Hanford 1989)

\section{Waste Stream}

PUREX Plant process condensate

242-A Evaporator process condensate

2724-W Laundry wastewater

$\mathrm{UO}_{3} \mathrm{P} 1$ ant process condensate

2101-M Laboratory wastewater

$\mathrm{UO}_{3} / \mathrm{U}$ Plants wastewater

$B$ Plant process condensate

Plutonium Finishing Plant wastewater

B Plant chemical sewer

241-AY, 241-AZ Tank Farms steam condensate
Total Organic

Contents, ppb

240,945

24,757

8,962

2,465

737

510

485

421

195

99

\subsubsection{Radionuclides}

The radioactivity within the 33 waste streams is wide-ranging, as seen in Table 10. The radionuclide occurrence frequency $(N)$ is shown for the samples collected. The fission and activation products ${ }^{90} \mathrm{Sr},{ }^{137} \mathrm{Cs}$, and ${ }^{239} \mathrm{Pu}$ are the most prevalent, as might be expected. Most of the radioactivity is concentrated in four waste streams, as shown in Table 11. Although the $\mathrm{N}$ Reactor effluent (105-N cooling water and fuel basin water) contained more than half of the total radioactivity in the 33 waste streams, this waste stream no longer exists in the same volume because the $N$ Reactor is not in operation, but rather in a cold-standby status (Millikin 1989).

\subsection{WASTE STREAM VOLUME ESTIMATES}

A best estimate of the volumes of the 33 waste streams is given in Table 12. The disposal sites for 163-N demineralized wastewater, the PUREX steam condensate, and the T Plant headend wastewater are listed by Westinghouse Hanford (1989) as being currently inactive. Therefore, the values in Table 12 for these streams are no longer valid. 
TABLE 8. Daily Discharge of Organic Analytes Based on Analyses and Effluent Volumes of the 33 Waste Streams (Westinghouse Hanford 1989)

\begin{tabular}{|c|c|}
\hline Organic Analyte & $\begin{array}{l}\text { Daily Discharge } \\
\text { Amount, } g\end{array}$ \\
\hline Tributyl phosphate & $13,977.750$ \\
\hline Tridecane & $8,676.711$ \\
\hline Tetradecane & $7,683.627$ \\
\hline Dodecane & $2,794.086$ \\
\hline Pentadecane & 303.900 \\
\hline Tetrachloroethylene & 284.070 \\
\hline Chloroform & 273.045 \\
\hline Bis(2-ethylhexyl) phthalate & 159.174 \\
\hline Undecane & 103.380 \\
\hline 2-butoxyethanol & 81.693 \\
\hline Butyl alcohol & 69.693 \\
\hline Acetone & 57.636 \\
\hline Hexadecane & 48.494 \\
\hline Methy 1 nitrite & 43.577 \\
\hline Dimethoxymethane & 41.934 \\
\hline Heptadecane & 38.466 \\
\hline Octadecane & 33.420 \\
\hline Decane & 33.359 \\
\hline Methyl formate & 28.197 \\
\hline Phenol & 24.870 \\
\hline $\mathrm{N}$-methoxymethanamine & 23.271 \\
\hline Di-n-butyl phthalate & 22.630 \\
\hline Benzyl alcohol & 16.071 \\
\hline Methylene chloride & 15.427 \\
\hline Di-n-octyl phthalate & 14.370 \\
\hline Benzoic acid & 13.646 \\
\hline Methyl ethyl ketone & 11.126 \\
\hline Butylbenzyl phthalate & 9.895 \\
\hline 2-methy 1-5-propylnonane & 9.615 \\
\hline Pelargic acid & 4.688 \\
\hline
\end{tabular}


TABLE 9. Organic Analytes Reported in Three 200 West Area Well lwater Samples

\begin{tabular}{l} 
Organic Analyte \\
\hline \multicolumn{1}{c}{ Volatile Compounds } \\
Carbon tetrachloride \\
Chloroform \\
Dichloromethane \\
Trichloroethylene \\
Cyclohexane \\
Methylcyclohexane \\
Toluene \\
2-butoxyethanol \\
2-ethyl-1-hexanol \\
Solvent Extractable Compounds \\
Tri-n-butylphosphate (TBP) \\
Di-n-octyladipate \\
Bis(2-ethylhexyl) phthalate \\
Di-n-octylphthalate \\
Phthalates, mixed \\
Chelating Agents
\end{tabular}

\begin{tabular}{ccc}
\multicolumn{3}{c}{ Concentration, ppb } \\
\hline We11 & We11 & We11 \\
$\underline{699-38-70}$ & $\underline{699-35-78}$ & $\underline{699-49-79}$
\end{tabular}

Ethy lened i aminetetraacet ic acid (EDTA)

5.95
13.56
2.94
0.90
0.71
12.91
9.51
11.33
2.56

$\begin{array}{ll}-- & -- \\ 0.33 & 81.90 \\ 1.15 & 0.29 \\ -- & -- \\ -- & -- \\ -- & 20.48 \\ -- & -- \\ -- & -- \\ -- & --\end{array}$

$\begin{array}{rrr}3 & -- & -- \\ -- & 590 & -- \\ 2 & -- & 2 \\ -- & 8 & -- \\ -- & 140 & 10\end{array}$

$\leqq 0.1$

$\leqq 0.1$ 
IABLE 10. Frequency (N) of Radionuclides in the 33 Waste Streams (Westinghouse Hanford 1989)

\begin{tabular}{|c|c|c|c|}
\hline Radionuclide & $\mathrm{N}$ & Radionuclide & $\mathrm{N}$ \\
\hline Gross $\beta$ & 1,745 & ${ }^{134} x e$ & 64 \\
\hline${ }^{137} \mathrm{Cs}$ & 1,006 & ${ }^{133} \mathrm{I}$ & 61 \\
\hline${ }^{239} \mathrm{Pu}$ & 941 & ${ }^{135} \times e$ & 60 \\
\hline${ }^{90} \mathrm{Sr}$ & 900 & ${ }^{135}{ }_{I}$ & 59 \\
\hline $3_{H}$ & 803 & ${ }^{24} \mathrm{Na}$ & 53 \\
\hline Gross $\alpha$ & 717 & $155_{\mathrm{Eu}}$ & 51 \\
\hline${ }^{60} \mathrm{Co}$ & 509 & $85_{K r}$ & 46 \\
\hline${ }^{54} \mathrm{Mn}$ & 464 & $88_{\mathrm{Kr}}$ & 41 \\
\hline${ }^{144} \mathrm{Ce}$ & 321 & $56_{\mathrm{Mn}}$ & 40 \\
\hline Total U & 279 & ${ }^{138} \mathrm{cs}$ & 40 \\
\hline $95_{\mathrm{Nb}}$ & 254 & ${ }^{239} \mathrm{~Np}$ & 40 \\
\hline${ }^{103} \mathrm{Ru}$ & 254 & ${ }^{91} \mathrm{sr}$ & 34 \\
\hline${ }^{238} \mathrm{Pu}$ & 243 & ${ }^{154} \mathrm{Eu}$ & 31 \\
\hline${ }^{59} \mathrm{Fe}$ & 214 & ${ }^{113} \mathrm{Sn}$ & 30 \\
\hline $95 \mathrm{Zr}$ & 200 & ${ }^{125} \mathrm{Sb}$ & 28 \\
\hline $140 \mathrm{La}$ & 190 & ${ }^{153} \mathrm{Sm}$ & 27 \\
\hline${ }^{141} \mathrm{Ce}$ & 175 & ${ }^{129} \mathrm{I}$ & 24 \\
\hline $131_{\mathrm{I}}$ & 155 & $65_{\mathrm{Zn}}$ & 24 \\
\hline${ }^{134} \mathrm{Cs}$ & 146 & ${ }^{87} \mathrm{Kr}$ & 24 \\
\hline${ }^{241} \mathrm{Pu}$ & 137 & ${ }^{125} \mathrm{Sb}$ & 22 \\
\hline $32 p$ & 136 & $97 \mathrm{Zr}$ & 16 \\
\hline${ }^{58} \mathrm{Co}$ & 130 & $234_{U}$ & 13 \\
\hline $9_{\text {Mo }}$ & 130 & $235 U$ & 13 \\
\hline${ }^{89} \mathrm{Sr}$ & 121 & $238_{U}$ & 13 \\
\hline $140_{\mathrm{Ba}}$ & 118 & $110 m_{A g}$ & 10 \\
\hline${ }^{106} \mathrm{Ru}$ & 117 & ${ }^{99} T c$ & 5 \\
\hline${ }^{147} \mathrm{Pm}$ & 114 & $122 \mathrm{Sb}$ & 3 \\
\hline${ }^{51} \mathrm{Cr}$ & 87 & $236 U$ & 2 \\
\hline $241_{A m}$ & 84 & ${ }^{41} \mathrm{Ar}$ & 1 \\
\hline 132 I & 80 & $\begin{array}{l}\text { Mixed fission } \\
\text { products }\end{array}$ & 1 \\
\hline
\end{tabular}


TABLE 11. Waste Streams with the Bulk of the Total Radioactivity in the 33 Waste Streams

\begin{tabular}{|c|c|c|}
\hline Waste Stream & $\begin{array}{c}\text { Total Activity, } \\
\text { Ci/yr }\end{array}$ & $\begin{array}{c}\text { Percent of } \\
\text { Total Activity }\end{array}$ \\
\hline N Reactor effluent $(1976-1988)$ & 2,400 & 54.00 \\
\hline PUREX Plant process condensate & 1,500 & 35.00 \\
\hline 242-A Evaporator cooling water & 280 & 6.30 \\
\hline 242-A Evaporator process condensate & 150 & 3.50 \\
\hline Total & 4,330 & 98.80 \\
\hline
\end{tabular}


TABLE 12. Waste Stream Volume Estimates (from Stordeur and Flyckt 1988)

\begin{tabular}{|c|c|c|}
\hline Effluent Stream & $\begin{array}{c}\text { Volume, (a) } \\
\text { millions of } \\
\text { L/yr }\end{array}$ & $\begin{array}{c}\text { Percent } \\
\text { of } \\
\text { Total Flow } \\
\end{array}$ \\
\hline $\begin{array}{l}\text { PUREX Plant cooling water } \\
\text { 242-A Evaporator cooling water } \\
\text { B Plant cooling water } \\
\text { 300 Area process wastewater } \\
\text { 241-A Tank Farm cooling water } \\
\text { PUREX Plant chemical sewer } \\
\text { N Reactor effluent C) } \\
\text { 163-N Demineralizer wastewater (c) } \\
\text { PUREX Plant steam condensate } \\
\text { B Plant chemical sewer } \\
\text { U03/U Plants wastewater } \\
\text { Plutonium Finishing Plant wastewater } \\
\text { S Plant wastewater } \\
\text { 284-E Powerhouse cooling water } \\
\text { 244-AR Vault cooling water } \\
\text { 284-W Powerhouse cooling water } \\
\text { T Plant wastewater } \\
\text { 2724-W Laundry wastewater } \\
\text { PUREX Plant process condensate } \\
\text { 400 Area secondary cooling water } \\
\text { 242-A Evaporator steam condensate } \\
\text { 222-S Laboratory wastewater } \\
\text { PUREX Plant ammonia scrubber condensate } \\
\text { 242-A Evaporator process condensate } \\
\text { 242-S Evaporator steam condensate } \\
\text { B Plant steam condensate } \\
\text { B Plant process condensate } \\
\text { 2101-M Laboratory wastewater } \\
\text { U0 Plant process condensate } \\
\text { AY } 9 \text { AZ Tank Farm steam condensate } \\
\text { 209-E Laboratory reflector water } \\
\text { T Plant laboratory (or headend) wastewater } \\
\text { 183-D Filter backflush wastewater }\end{array}$ & $\begin{array}{l}7,800.00 \\
5,300.00 \\
2,800.00(\mathrm{~b}) \\
1,900.00(\mathrm{~b}) \\
880.00 \\
840.00 \\
760.00 \\
600.00 \\
590.00(\mathrm{~d}) \\
350.00 \\
340.00 \\
200.00 \\
200.00 \\
180.00(\mathrm{~b}) \\
120.00 \\
110.00(\mathrm{~b}) \\
72.00(\mathrm{~b}) \\
61.00 \\
51.00 \\
49.00(\mathrm{~b}) \\
45.00 \\
34.00 \\
28.00 \\
25.00 \\
14.00 \\
4.20 \\
3.90(\mathrm{~d}) \\
3.80(\mathrm{~b}) \\
0.64 \\
0.23(\mathrm{e}) \\
\mathrm{NA}(\mathrm{f}) \\
\mathrm{NA} \\
\mathrm{NA} \\
\end{array}$ & $\begin{array}{r}33.39 \\
22.69 \\
11.99 \\
8.13 \\
3.73 \\
3.60 \\
3.25 \\
2.57 \\
2.53 \\
1.50 \\
1.46 \\
0.86 \\
0.86 \\
0.77 \\
0.51 \\
0.47 \\
0.31 \\
0.27 \\
0.22 \\
0.21 \\
0.20 \\
0.15 \\
0.12 \\
0.11 \\
0.06 \\
0.02 \\
0.02 \\
0.02 \\
0.00 \\
0.00\end{array}$ \\
\hline Total & $23,336.18$ & 100.00 \\
\hline $\begin{array}{l}\text { (a) } 1987 \text { flow data (except as noted). } \\
\text { (b) Estimated. } \\
\text { (c) These have decreased as a result of the } \\
\text { into cold-standby status. } \\
\text { (d) } 1986 \text { flow data used. } \\
\text { (e) } 1985 \text { flow data used. } \\
\text { (f) NA = Not available, minor contribution }\end{array}$ & otal. & \\
\hline
\end{tabular}




\subsection{CHARACTERISTICS OF HANFORD SEDIMENTS}

Cation exchange capacity (CEC) is one of the more important soil characteristics associated with determining the fate of constituents when liquid waste is disposed into sediments. The CEC values for Hanford Site sediments were given by McHenry (1957), Routson et al. (1981), and Delegard and Barney (1983) for the 200 Areas (process areas) and vicinity and by Bensen et al. (1963) for the 100 Areas (reactors). These CEC values are not necessarily comparable because the results are a function of how the CEC is measured, including the cation used to saturate the exchange sites and the one used to replace the adsorbed cation. More recent CEC particle size and carbon data for 200 Area (separations areas) and 100 Area (reactors) sediments are given in Table 13. The typical 200 Area sediment is high in sand content, with an average CEC of $4.3 \mathrm{meq} / 100 \mathrm{~g}$ and an average organic carbon (OC) content of slightly less than $0.10 \mathrm{wt} \%$. The 100 Area sediments also have very low values for $O C$ content. Total carbon, in the case of the 100 Area sediments, was determined by microcombustion and infrared analysis. Particle size analysis for the 200 Area soils was conducted using the technique of Gee and Bauder (1986), and total carbon was determined by dry combustion with the coulometric method of Huffman (1977). Inorganic carbon was determined by the same coulometric method after the samples had been digested for 10 min in $3 \underline{N}$ $\mathrm{HCl}$ at $80^{\circ} \mathrm{C}$ to release all inorganic carbon. Both the total and the inorganic carbon procedures were calibrated with reagent-grade $\mathrm{CaCO}_{3}$. Organic carbon was obtained as the difference, if any, between the total carbon and the inorganic carbon.

The organic carbon content of the soil/sediment is important because neutral hydrophobic organic compounds (compounds having a water solubility of less than a few parts per million) have been shown to adsorb preferentially onto the organic carbon fraction of the soil (Lambert et al. 1965; Briggs 1973). Lambert et al. suggested that the role of organic matter in the sediment was similar to that of an organic solvent in solvent extraction and that the partitioning of a neutral organic compound between sediment organic matter and water should correlate well with its partitioning between water and an immiscible solvent. Briggs (1973) developed a regression equation relating 
TABLE 13. Recent Sediment Data That Include Organic Carbon Values

\begin{tabular}{|c|c|c|c|c|c|c|c|c|}
\hline \multirow[b]{2}{*}{ We11 Number } & \multirow[b]{2}{*}{ Depth, ft } & \multirow{2}{*}{$\begin{array}{l}\text { Cation } \\
\text { Exchange } \\
\text { Capacity, } \\
\text { meq } / 100 \mathrm{~g}\end{array}$} & \multicolumn{6}{|c|}{$W t \%$} \\
\hline & & & $\mathrm{TC}(\mathrm{a})$ & $\mathrm{IC}(\mathrm{b})$ & $O C(c)$ & Sand & Silt & Clay \\
\hline 299-E28-26 & $39-40$ & 5.1 & 0.10 & 0.04 & 0.06 & 61.59 & 16.15 & $\overline{22.26}$ \\
\hline $\begin{array}{l}299-E 28-26 \\
290-E 28-26\end{array}$ & $129-130$ & 4.2 & 0.39 & 0.18 & 0.21 & 93.82 & 4.40 & 1.78 \\
\hline & $\begin{array}{l}129-130 \\
294-295\end{array}$ & 4.4 & & 0.16 & 0.00 & 90.63 & 6.06 & 3.31 \\
\hline 299-E28-26 & $319-320$ & $\begin{array}{l}1.6 \\
2.6\end{array}$ & $\begin{array}{l}0.04 \\
0.02\end{array}$ & $\begin{array}{l}0.04 \\
0.01\end{array}$ & $\begin{array}{l}0.00 \\
0.01\end{array}$ & $\begin{array}{l}85.66 \\
91.17\end{array}$ & $\begin{array}{r}11.00 \\
7.48\end{array}$ & $\begin{array}{l}3.34 \\
1.35\end{array}$ \\
\hline $299-\mathrm{E} 33-30$ & $39-40$ & 3.6 & 0.13 & 0.11 & 0.02 & 70.37 & 20.33 & 9.31 \\
\hline $299-E 33-30$ & $139-140$ & 2.5 & 0.15 & 0.10 & 0.05 & -- & -- & -- \\
\hline 299-E34-2 & $49-50$ & 4.7 & 0.22 & 0.11 & 0.11 & 63.63 & 26.37 & 10.00 \\
\hline $299-E 34-2$ & $145-150$ & 2.0 & 0.14 & 0.18 & 0.00 & 88.36 & 6.45 & 5.09 \\
\hline $299-E 34-2$ & 230 & 4.2 & 0.09 & 0.03 & 0.06 & 66.45 & 14.65 & 18.89 \\
\hline $299-E 34-3$ & $49-50$ & 2.2 & 0.11 & 0.07 & 0.04 & 74.68 & 19.99 & 5.33 \\
\hline $299-E 34-3$ & $119-120$ & 3.5 & 0.26 & 0.14 & 0.12 & 93.79 & 4.83 & 1.38 \\
\hline $299-E 34-3$ & 120 & 2.4 & 0.78 & 0.13 & 0.65 & 93.46 & 4.46 & 2.08 \\
\hline 299-E34-3 & $164-165$ & 2.9 & 0.13 & 0.08 & 0.05 & 68.87 & 27.29 & 3.85 \\
\hline $299-E 34-3$ & 210 & 2.9 & 0.03 & 0.04 & 0.00 & 74.29 & 16.96 & 8.76 \\
\hline $299-W 7-2$ & $64-65$ & 6.0 & 0.48 & 0.73 & 0.00 & -- & -- & -- \\
\hline $299-W 7-2$ & $94-95$ & 2.3 & 0.13 & 0.13 & 0.00 & 88.28 & 9.32 & 2.40 \\
\hline $9-W 7-2$ & 155 & 2.2 & 0.04 & 0.01 & 0.03 & & -- & \\
\hline $299-w 7-2$ & 220 & 3.6 & 0.15 & 0.15 & 0.00 & 78.92 & 16.51 & 4.58 \\
\hline $299-W 7-3$ & 450 & 3.2 & 0.02 & 0.01 & 0.01 & 87.24 & 9.25 & 3.52 \\
\hline $299-W 7-5$ & 10 & 6.9 & 0.32 & 0.20 & 0.12 & -- & -- & -- \\
\hline 299-W10-13 & 45 & 2.9 & 0.27 & 0.19 & 0.08 & -- & -- & -- \\
\hline 299-W10-13 & 115 & 4.1 & 0.28 & 0.26 & 0.02 & -- & -- & -- \\
\hline 299-W10-13 & 160 & 1.5 & 0.42 & 0.04 & 0.38 & -- & -- & -- \\
\hline 299-W10-13 & 160 & 1.8 & 0.07 & 0.04 & 0.03 & -- & -- & -- \\
\hline $299-W 10-13$ & 200 & 3.2 & 0.03 & 0.01 & 0.02 & 73.67 & 12.80 & 13.53 \\
\hline 299-W10-13 & 240 & 6.2 & 0.01 & 0.00 & 0.01 & 78.38 & 11.00 & 10.63 \\
\hline 299-W10-14 & 440 & 6.2 & 0.05 & 0.03 & 0.02 & -- & -- & -- \\
\hline 299-W15-16 & 40 & 9.0 & 0.24 & 0.14 & 0.10 & -- & -- & -- \\
\hline 299-W15-16 & 110 & 5.3 & 0.17 & 0.17 & 0.00 & 74.30 & 12.10 & 13.60 \\
\hline $299-W 15-16$ & $149-150$ & 8.5 & 2.75 & 2.58 & 0.18 & -- & -- & -- \\
\hline 299-W15-16 & 225 & 4.0 & 0.02 & 0.10 & 0.01 & -- & -- & -- \\
\hline W15-17 & 425 & 6.1 & 1.07 & 0.16 & 0.91 & -- & -- & -- \\
\hline 299-W15-17 & 425 & 4.9 & 0.13 & 0.10 & 0.03 & -- & -- & -- \\
\hline $299-W 18-21$ & 40 & 5.3 & 0.17 & 0.18 & 0.00 & -- & -- & -- \\
\hline $299-W 18-21$ & 40 & 5.9 & 0.67 & 0.16 & 0.51 & -- & -- & -- \\
\hline $299-W 18-21$ & $94-95$ & 3.3 & 0.25 & 0.28 & 0.00 & -- & -- & -- \\
\hline W18-21 & $139-140$ & 5.3 & 0.48 & 0.44 & 0.04 & -- & -- & -- \\
\hline 299-W18-21 & 210 & 8.1 & 0.02 & 0.00 & 0.02 & $=-$ & $\overline{-i} 72$ & $\overline{-i}$ \\
\hline $299-W 18-22$ & $429-431$ & 6.2 & 0.09 & 0.05 & 0.04 & 73.43 & 15.73 & 10.85 \\
\hline
\end{tabular}

\footnotetext{
(a) TC = total carbon, $\mathrm{TC}=\mathrm{IC}+\mathrm{OC}$.

(b) IC = inorganic carbon.

(c) $O C=$ organic carbon.
} 
soil/sediment sorption of phenyl urea herbicides to their octanol-water partition coefficient, $K_{o} / w \cdot$ Karickhoff et al. (1979) then used this concept to determine sorption isotherms for 10 hydrophobic organic compounds on natural sediments.

The adsorption data for all of the organic compounds fit well, over a broad range of water phase concentrations, to linear isotherms where $X=k_{p} C$. The variable $X$ is the concentration of sorbate ( $p p b)$ on the sediment relative to the sediment's dry weight, $C$ is the equilibrium solution sorbate concentration ( $p p b)$, and $K_{p}$ is the partition coefficient (unitless). When adsorption depends on only organic carbon, $k_{o c}=k_{p} / f_{o c}$. The $f_{o c}$ is the fractional mass of organic carbon in the sediment, and $K_{O C}$ is a normalized partition coefficient. When the $\log \mathrm{K}_{\mathrm{o} / \mathrm{w}}$ (octanol-water partition coefficient) is plotted versus the $\log K_{o c}$ or $\log S$ (water solubility expressed as a mole fraction), relationships such as $\log \mathrm{K}_{\mathrm{oc}}=1.00 \log \mathrm{K}_{\mathrm{o}} / \mathrm{w}$ - 0.21 and $\log K_{o c}=-0.54 \log S+0.44$ were obtained. The covariation of $K_{o c}$ and $K_{0 / w}$ were linear, but $K_{0 c}$ varies nonlinearly with $S$.

These relationships would be very useful as they make it possible for the hydrophobic organic compound distribution coefficients to be easily computed from available data, except for one circumstance. As can be seen from Table 12, Hanford sediments are relatively low in organic carbon content, averaging slightly less than $0.1 \mathrm{wt} \%$. Hanford sediments often contain no organic carbon at all. According to Means et al. (1982), the reliability of predictive equations is impaired for substrates with very low carbon contents, such as the Hanford sediments. Means et al. found that correlations between $K_{o c}$ and $K_{p}$ were erratic for sediments that contain less than 1.0 wt\% organic carbon content, as do Hanford sediments. Hence, application of generic hydrophobic organics-water-sediment relationships to Hanford sediments cannot be justified, except as a means of roughly estimating Hanford sediment reactions with organic analytes.

Hydrophilic compounds, by definition, prefer an aqueous environment and minimal sediment sorption can be expected. Some organic compounds can dissociate, such as the benzoic or hexadecanoic acids reported in Table 5 . These ionized compounds are theoretically able to adsorb on the sediment as an exchangeable cation or anion under the appropriate conditions. However, 
benzoic acid is not known to sorb on sediments (see Appendix A) and little is known about the sorption properties of the other dissociating compounds shown in Table 5. 


\subsection{SEDIMENT INTERACTIONS}

Transport of solutes (including contaminants) in the subsurface is controlled by advection, hydrodynamic dispersion, molecular diffusion, and geochemical interaction. Advection and hydrodynamic dispersion refer to movement of solute at a rate dependent on the various water pathways and velocities. Molecular diffusion refers to the gradual mixing of molecules of two or more substances as a result of random motion and/or a chemical concentration gradient. Diffusion flux spreads solute via the concentration gradient (i.e., according to Fick's law). Diffusion is a dominant transport mechanism when advection is insignificant but is usually negligible when water is being advected in response to various forces. Variability in the advection process gives rise to hydrodynamic dispersion. Hydrodynamic dispersion is a result of variability in travel paths, that is, velocities, taken by the advected solute. Geochemical interactions cover all reactions that are driven by chemical and biochemical forces.

Once the liquid wastes contact the vadose zone sediments, they can chemically interact with the soils and sediments. The major geochemical processes affecting transport include dissolution/precipitation, adsorption/desorption, filtration of colloids and small suspended particles, diffusion into micropores within mineral grains, and volatilization and eventual escape to the atmosphere. Dissolution/precipitation and adsorption/desorption are considered the most important for the inorganic wastes present in the 33 active waste streams at the Hanford Site. However, when assessing the organics in the waste streams, volatilization should also be considered. Furthermore, for the disposal of low-level radioactive waste (LLW) at the Hanford Site, precipitation is likely to be significant only for cases where $\mathrm{pH}$ and/or redox changes occur when waste streams contact the sediments. In most active liquid discharge situations at the Hanford Site, we speculate that adsorption processes are the key to inorganic contaminant migration. The knowledge base for the environmental fate of organics identified in the wastes is meager, and we cannot offer an opinion on what specific process dominates their fate. 
Adsorption reactions have been acknowledged to be the most important contaminant retardation process in far-field transport analyses conducted for hazardous waste-disposal options. Adsorption processes are known to increase the travel times for some contaminants by $10^{3}$ to $10^{6}$ times relative to the groundwater. Such long travel times allow nuclides to decay to lower concentrations and less hazardous nuclides before they reach the accessible environment (i.e., the biosphere). Furthermore, some adsorption processes are effectively irreversible and permanently prevent contaminants from reaching the groundwater, thus preventing their release to the biosphere.

\subsection{CONSTANT DISTRIBUTION COEFFICIENT}

To predict the effects of retardation using mathematical codes, adsorption processes must be described in quantitative terms. An empirical parameter, the distribution coefficient (often called $R_{d}$ or $K_{d}$ ), is readily measured by laboratory experimentation and allows such a quantitative estimate of migration and retardation. Knowledge of the $R_{d}$ and of either media bulk density and porosity (for porous flow) or media fracture surface area, aperture width, and matrix diffusion attributes (for fracture flow) allows calculation of the retardation factor, $R$ or $R_{f}$. The retardation factor is defined as $R=\frac{V_{W}}{V_{n}}$, where $V_{W}$ is the velocity of water through a control volume and $V_{n}$ is the velocity of the contaminant.

For one-dimensional advection-dispersion flow with chemical reaction, the transport equation can be written as

$$
\frac{\partial C_{i}}{\partial t}=\frac{D_{x} \frac{\partial^{2} C_{i}}{\partial x^{2}}-V_{x} \frac{\partial C_{i}}{\partial x}}{R_{j}}
$$

where $C_{i}=$ concentration of a particular radioactive species $i$ in solution (mass/length ${ }^{3}$ )

$D_{x}=$ dispersion coefficient of species $i$ (length ${ }^{2} /$ time)

$V_{x}=$ pore velocity of groundwater (length/time)

$R_{i}=$ retardation factor for species $i$.

(For simplicity, radioactive decay has been left out.) 
The retardation factor is a function of all of the contaminant retardation mechanisms: 1) chemical precipitation/dissolution of bulk solid phases, 2) chemical substitution of one element for another in a solid phase, 3) exchange of a stable isotope of an element with a radioactive isotope in solution, 4) physical filtration of colloids, 5) cation and anion exchange, and 6) adsorption (Muller et a1. 1983), plus for organic compounds, 7) microbial and other degradation. Typically, all these mechanisms are melded into a single empirical distribution coefficient that implicitly assumes that the reactions go to equilibrium and are reversible and that the chemical environment along a solute flow path does not vary over either space or time. The limitations associated with these assumptions are well known to investigators, but the current paucity of Hanford Site-specific geochemical data precludes a more rigorous conceptual model at this time. Even though geochemical processes may be irreversible or at least directionally dependent (e.g., adsorption and de-sorption may be represented by different model parameters), the assumption of reversibility and use of single-valued model parameters are standard with the justification that the approach builds conservatism into the analysis.

In the constant $R_{d}$ model, the distribution of the contaminant of interest between the solid adsorbent and solution is assumed to be a constant value. There is no explicit accommodation of dependence on characteristics of the sediments, groundwater, or contaminant concentration. Typically, an $R_{d}$ value for a given contaminant is determined in the laboratory using sediment from the study area and actual or simulated groundwater to which a radionuclide tracer is added. Then

$$
\mathrm{R}_{\mathrm{d}}=\frac{\text { amount of radionuclide adsorbed on solid per gram }}{\text { amount of radionuclide in solution per milliliter }}
$$

The mass or activity of the tracer must be sufficient to facilitate good counting statistics. The solids and liquids are often equilibrated by contacting the solid with several aliquots of the liquid before adding the radiotracer, to attempt to approach the condition expected in the field. 
Several standardized laboratory techniques are commonly used to determine this ratio (Serne and Relyea 1983; ASTM 1984).

Most of the laboratory experiments performed to measure distribution coefficients do not systematically investigate the effect of various important parameters and do not attempt to identify the processes causing the adsorption that is observed. Because it is an empirical measurement, the $R_{d}$ value does not necessarily denote an equilibrium value or require some of the other assumptions inherent in the use of the more rigorous term $K_{d}$. The term $R_{d}$ will be used to refer to the observed distribution ratio for the nuclide between the solid and solution. The term $k_{d}$ will be reserved for true equilibrium reactions that show reversibility and that do not yield a distribution ratio that is dependent on the tracer concentration in solution.

It is customary with the constant $R_{d}$ model to measure the total concentration or radioactivity of the tracer and thus to treat the tracer as being one species. This assumption is not an inherent requirement, but it is generally applied for convenience. If the tracer is known to distribute among several species and the distribution can be measured or predicted, separate $R_{d}$ values can and should be calculated for each species.

This conceptual model, which depends on experimental determination of the distribution coefficient $R_{d}$, is quite simple, but it is also limited in that it does not address sensitivity to changing conditions. If the groundwater properties (e.g., $\mathrm{pH}$, dissolved solids content) change, a new value for $R_{d}$ must be obtained.

The constant $R_{d}$ mode 1 is mathematically very simple and readily incorporated into transport models and codes via the retardation factor term. That is, for porous flow

$$
R=1+\frac{\rho_{b}}{\Phi \epsilon} R_{d}
$$

or

$$
\mathrm{R}=1+\frac{1-\Phi \epsilon}{\Phi \epsilon} \rho_{\mathrm{p}} \mathrm{R}_{\mathrm{d}}
$$


where $\mathrm{R}=$ the retardation factor

$\rho_{\mathrm{b}}=$ porous media bulk density (mass/length ${ }^{3}$ )

$\Phi \epsilon=$ effective porosity at saturation of media

$R_{d}=$ distribution coefficient

$\rho_{p}=$ particle density (mass/length ${ }^{3}$ ).

For the constant $R_{d}$ model, the retardation factor $(R)$ is a constant for each layer of geologic media (each layer is assumed to have a constant bulk density and saturated effective porosity). Therefore, this transport equation does not require knowledge of any other parameters, such as $\mathrm{pH}$ or surface area, and it is easily solved to determine the solution concentration as a function of time and for any given point. However, the use of the constant $R_{d}$ conceptualization in the retardation factor has caused criticism because few natural groundwater pathways are spatially or geochemically homogeneous enough for the retardation factor of a species to remain constant.

\subsection{INTRODUCTION TO ESTIMATING ADSORPTION CONSTANTS}

The purpose of this subsection is to document any available Hanford Sitespecific data that provide actual $R_{d}$ values for identified contaminants. Because the database is small and the constant $R_{d}$ adsorption model is simplistic, we do not discuss the adsorption potential of each contaminant from each waste stream separately.

As mentioned above, the adsorption tendencies of contaminants are influenced by characteristics of the waste stream, sediments, and contaminants. Vadose zone sediments at the Hanford Site do not show large ranges for such characteristics as organic carbon content, CEC, soil paste $\mathrm{pH}$, and so on. Thus we do not gain much understanding of contaminant adsorption by attempting detailed differentiation (i.e., categorization) of Hanford sediments. On the other hand, the effects of solution characteristics (e.g., $\mathrm{pH}$, Eh, dissolved solids, dissolved organic content) on inorganic contaminant adsorption are better understood and the ranges of solution characteristics of Hanford waste streams can be quite large. Therefore, all available waste stream data have been categorized into generic types based on five independent parameters (Figure 1). 


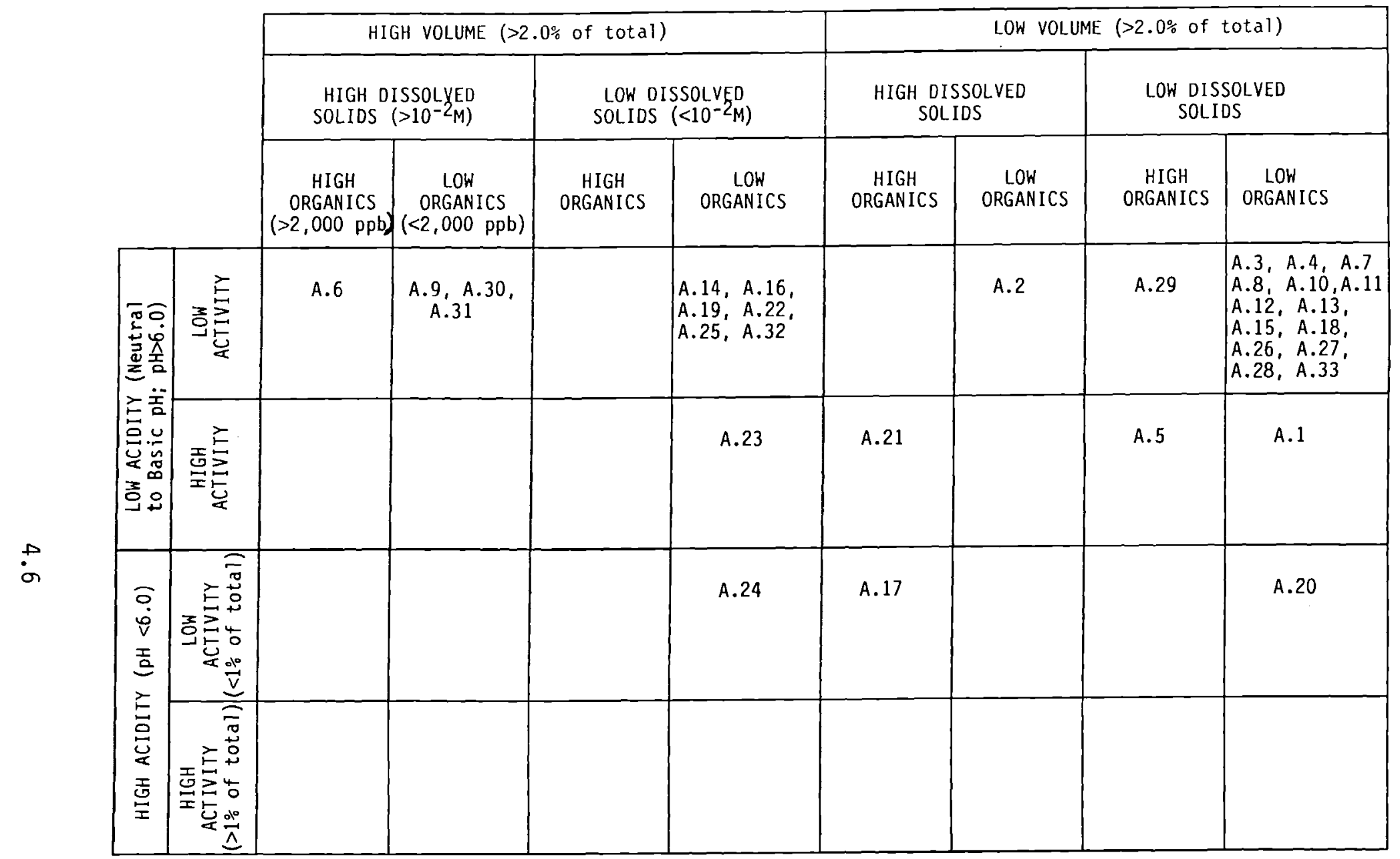

FIGURE 1. Classification of Waste Streams Based on Five Key Parameters of Acidity, Radioactivity, Organic Content, Dissolved Solids Content, and Waste Stream Volume. The definitions for the parameters are given in parentheses under each heading. The waste stream identifications (A.1, etc.) are listed in Table 14. 
TABLE 14. Waste Stream Identification

Designation

Waste Stream

A.1

A. 2

A. 3

A. 4

A. 5

A. 6

A.7

A. 8

A. 9

A. 10

A. 11

A. 12

A. 13

A. 14

A. 15

A. 16

A.17

A. 18

A. 19

A. 20

A. 21

A. 22

A. 23

A. 24

A. 25

A. 26

A. 27

A.28

A. 29

A. 30

A. 31

A. 32

A. 33
$N$ Reactor effluent

163-N Demineralizer wastewater

183-D Filter backflush wastewater

PUREX Plant chemical sewer

PUREX Plant process condensate

PUREX Plant ammonia scrubber condensate

PUREX Plant steam condensate

PUREX Plant cooling water

B Plant chemical sewer

B Plant process condensate

B Plant steam condensate

B Plant cooling water

Plutonium Finishing Plant wastewater

$S$ Plant wastewater

$T$ Plant headend wastewater

$T$ Plant wastewater

$\mathrm{UO}_{3}$ Plant process condensate

$\mathrm{UO}_{3} / \mathrm{U}$ Plants wastewater

241-A Tank Farm cooling water

241-AY, 241-AZ Tank Farms steam condensate

242-A Evaporator process condensate

242-A Evaporator steam condensate

242-A Evaporator cooling water

242-S Evaporator steam condensate

244-AR Vault cooling water

209-E Laboratory reflector water

222-S Laboratory wastewater

2101-M Laboratory wastewater

2724-W Laundry wastewater

284-E Powerplant wastewater

284-W Powerplant wastewater

300 Area process wastewater

400 Area secondary cooling water 
A volume quantity of more than $2 \%$ of the total waste stream flow was arbitrarily chosen as the high-volume category. This choice put nine of the 33 waste streams into the high-volume category. These nine streams contained $92 \%$ of the total waste stream volumes (Table 12). It should be kept in mind, however, that these volume data are from 1988 and may not be accurate for present waste stream flows.

The dissolved solids content of $10^{-2} \underline{M}$ was chosen to define the high category because natural groundwater at Hanford contains dissolved solids ranging from $1 \times 10^{-3}$ to $7 \times 10^{-3}$ M. Migration of many cations through sediments in pore waters would tend to be accelerated by contact with highionic-strength solutions. Hence, streams showing dissolved solids contents higher than $10^{-2} \underline{M}$ would tend to accelerate ion migration.

The $\mathrm{pH}$ parameter was used to define a neutral-to-basic category $(\mathrm{pH}>6.0)$ and an acidic $(\mathrm{pH}<6.0)$ category, with acidity being known to adversely affect the sorption of many cationic radionuclides (McHenry 1954, 1957, 1958), such as ${ }^{90} \mathrm{Sr}$ and ${ }^{137} \mathrm{Cs}$, as well as the transuranics. Therefore, acidic streams, of which there are only three, would be higher-priority candidates for treatment or cessation than the 30 neutral-to-alkaline streams.

Four of the waste streams included $98.8 \%$ of the radioactivity being subjected to ground disposal. One of the four high-activity streams, $N$ Reactor effluent (A.1), is no longer produced. The high-activity category was defined to include any streams having more than $1 \%$ of the total waste stream radioactivity. It is assumed that the higher radionuclide concentrations tend to enhance radionuclide migration.

The organic contents of the waste streams are generally low, ranging from about 100 to $241,000 \mathrm{ppb}$. There are only four streams with organic contents above 2,000 ppb (Table 7), and only 10 of the 33 streams have measurable organic contents at all. Therefore, the dividing line between categories was placed at an organic content of $2,000 \mathrm{ppb}$. Waste streams having organic contents above 2,000 ppb are considered to be high in organics, although the presence of these organics may or may not be detrimental to radionuclide sorption on sediments. Very little work has been done to date on the effects of organics on radionuclide sorption on Hanford soils. 
Table 14 lists the 33 waste streams and their designations (A.1 to A.33). Figure 1 shows each waste stream as a member of one of the 32 categories based on the data obtained from Westinghouse Hanford (1989). In general, migration potential and resultant hazard from a waste stream increase with increasing volume, dissolved solids, organics, radionuclide activity, and acidity. Conversely, waste streams with low values for volume, dissolved solids, activity, and organics and a high value for $\mathrm{pH}$ are not likely to promote migration of contaminants.

Most of the active waste streams identified in Table 14 are in the categories that do not promote migration. Waste streams A.3, A.4, A.7, A.8, A.10 to A.13, A.15, A.18, A.26 to A.28, and A.33 have low values for all five parameters (note that low acidity $=$ high $\mathrm{pH}$ ). Waste streams A.14, A.16, A.19, A.22, A.25, and A.32 are low in all parameters but discharge volume. These "low-value" waste streams represent chemical sewerage, steam and process condensates, cooling waters, and miscellaneous laboratory wastewaters.

Three waste streams have three high values and two low values for the five parameters. These three streams may warrant closer scrutiny than all of the others because of their higher potential for contaminant migration. The three waste streams are the PUREX ammonia scrubber condensate, which has high volume, high dissolved solids content, and high organic content; $\mathrm{UO}_{3} \mathrm{Plant}$ process condensate, which has high dissolved solids, high organics, and acid $\mathrm{pH}$; and 242-A evaporator steam condensate, which has high dissolved solids, high organics, and high radionuclide content.

\subsection{DISTRIBUTION COEFFICIENTS FOR INORGANICS AND RADIONUCLIDES}

Figures 2 through 16 provide estimates of distribution coefficient $\left(R_{d}\right)$ values for selected inorganic and radionuclide constitutents found in the 33 active waste streams. $R_{d}$ values are presented for each of eight waste types based on the waste streams' $\mathrm{pH}$, total dissolved solids content, and organic content (see Figure 1 to determine which waste streams belong in each category).

The $R_{d}$ figures provide estimates for each waste stream category for a typical Hanford sediment. To obtain accurate $R_{d}$ values requires testing of 


\begin{tabular}{|c|c|c|c|c|}
\hline & \multicolumn{2}{|c|}{ HIGH DISSOLVED SOLIDS } & \multicolumn{2}{|c|}{ LOW DISSOLVED SOLIOS } \\
\hline & HIGH ORGANICS & LOW ORGANICS & HIGH ORGANICS & LOW ORGANICS \\
\hline $\begin{array}{l}\text { NEUTRAL } \\
\text { TO BASIC }\end{array}$ & $\begin{array}{l}3-15 \\
(5)\end{array}$ & $\begin{array}{l}7-70 \\
(7.5)\end{array}$ & $\begin{array}{l}15-70 \\
(15)\end{array}$ & $\begin{array}{c}15-200 \\
(20)\end{array}$ \\
\hline ACID & $\begin{array}{l}0.1-5 \\
(1.5)\end{array}$ & $\begin{array}{l}0.5-15 \\
(3.5)\end{array}$ & $\begin{array}{l}3-15 \\
(7.5)\end{array}$ & $\begin{array}{l}7-15 \\
(10)\end{array}$ \\
\hline
\end{tabular}

FIGURE 2. $R_{d}$ Estimates ( $\mathrm{mL} / \mathrm{g}$ ) for Beryllium, Calcium, and Magnesium. The numbers in parentheses are conservative $R_{d}$ ranges above them. See Figure 1 for parameter definitions. 


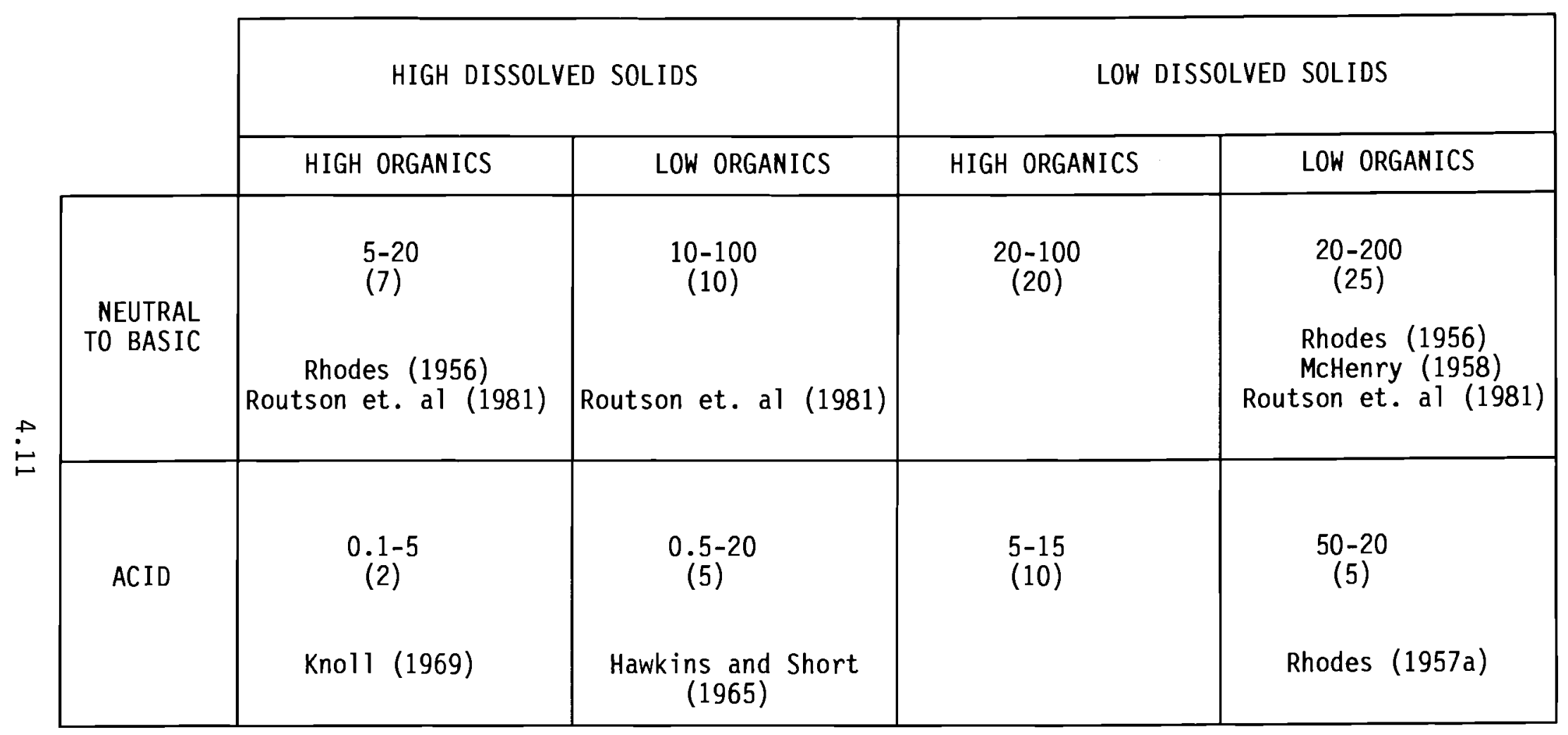

FIGURE 3. $R_{d}$ Estimates $(\mathrm{mL} / \mathrm{g})$ for Strontium and Barium. The numbers in parentheses are conservative $R_{d}$ averages estimated from the $R_{d}$ ranges above them. See Figure 1 for parameter definitions. 


\begin{tabular}{|c|c|c|c|c|}
\hline & \multicolumn{2}{|c|}{ HIGH DISSOLVED SOLIDS } & \multicolumn{2}{|c|}{ LOW DISSOLVED SOLIDS } \\
\hline & HIGH ORGANICS & LOW ORGANICS & HIGH ORGANICS & LOW ORGANICS \\
\hline NFIITRAL & $\begin{array}{r}0-30 \\
\text { (1) }\end{array}$ & $\begin{array}{r}0-30 \\
(2)\end{array}$ & $\begin{array}{r}1-30 \\
(2)\end{array}$ & \\
\hline ACID & $\begin{array}{r}0-10 \\
(0)\end{array}$ & $\begin{array}{r}0-10 \\
(0)\end{array}$ & $\begin{array}{r}0-10 \\
(0)\end{array}$ & $\begin{array}{r}0-10 \\
\text { (1) }\end{array}$ \\
\hline & & & & \\
\hline
\end{tabular}

FIGURE 4. R Estimates ( $\mathrm{mL} / \mathrm{g}$ ) for Lithium, Potassium, Sodium, and Ammonium. The numbers in parentheses are conservative $R_{d}$ ranges above them. See Figure 1 for parameter definitions. 


\begin{tabular}{|c|c|c|c|c|}
\cline { 2 - 5 } \multicolumn{1}{c|}{} & \multicolumn{2}{c|}{ HIGH DISSOLVED SOLIDS } & \multicolumn{2}{c|}{ LOW DISSOLVED SOLIDS } \\
\cline { 2 - 5 } & HIGH ORGANICS & LOW ORGANICS & HIGH ORGANICS & LOW ORGANICS \\
\hline $\begin{array}{c}\text { NEUTRAL } \\
\text { TO BASIC }\end{array}$ & $\begin{array}{c}0.1-10 \\
(3)\end{array}$ & $\begin{array}{c}5-20 \\
(10)\end{array}$ & $\begin{array}{c}0.1-10 \\
(3)\end{array}$ & $\begin{array}{c}10-3000 \\
(50)\end{array}$ \\
\hline \multirow{\omega}{*}{$\begin{array}{c}\text { Haney (1967) } \\
\text { Barney (1978) }\end{array}$} & Routson et al. (1981) & $\begin{array}{c}\text { Wilding and Rhodes } \\
(1963)\end{array}$ & Routson et al (1981) \\
\hline ACID & $\begin{array}{c}\text { Haney (1957) } \\
\text { Rhodes and Nelson } \\
(1957)\end{array}$ & $\begin{array}{c}0.2-20 \\
(5)\end{array}$ & 0 & $\begin{array}{c}0.2-20 \\
(5)\end{array}$ \\
\hline
\end{tabular}

FIGURE 5. R $R_{d}$ Estimates $(\mathrm{mL} / \mathrm{g})$ for Cobalt, Iron, and Manganese. The numbers in parentheses are conservative $R_{d}$ ranges above them. See Figure 1 for parameter definitions. 


\begin{tabular}{|c|c|c|c|c|}
\cline { 2 - 5 } \multicolumn{1}{c|}{} & \multicolumn{2}{c|}{ HIGH DISSOLVED SOLIDS } & \multicolumn{2}{c|}{ LOW DISSOLVED SOLIDS } \\
\cline { 2 - 5 } & HIGH ORGANICS & LOW ORGANICS & HIGH ORGANICS & LOW ORGANICS \\
\hline & $\begin{array}{c}0-100 \\
(10)\end{array}$ & $\begin{array}{c}0-200 \\
(30)\end{array}$ & $\begin{array}{c}0-200 \\
(10)\end{array}$ & $\begin{array}{c}100-200 \\
(30)\end{array}$ \\
NEUTRAL \\
TO BASIC
\end{tabular}

FIGURE 6. Rd Estimates $(\mathrm{mL} / \mathrm{g})$ for Lead, Zinc, Cadmium, Copper, Nickel, Silver, and Mercury. The numbers in parentheses are conservative $R_{d}$ ranges above them. See Figure 1 for parameter definitions. 


\begin{tabular}{|c|c|c|c|c|}
\hline & \multicolumn{2}{|c|}{ HIGH DISSOLVED SOLIDS } & \multicolumn{2}{|c|}{ LOW DISSOLVED SOLIDS } \\
\hline & HIGH ORGANICS & LOW ORGANICS & HIGH ORGANICS & LOW ORGANICS \\
\hline $\begin{array}{l}\text { NEUTRAL } \\
\text { TO BASIC }\end{array}$ & $\begin{array}{l}0-2 \\
(0)\end{array}$ & $\begin{array}{c}\begin{array}{c}0-5 \\
(0)\end{array} \\
\text { Haney (1967) } \\
\text { Ames and Rai (1978) }\end{array}$ & $\begin{array}{l}0-2 \\
(0)\end{array}$ & $\begin{array}{l}0-40 \\
(0)\end{array}$ \\
\hline ACID & $\begin{array}{l}0-5 \\
(0)\end{array}$ & $\begin{array}{l}2-20 \\
(2)\end{array}$ & $\begin{array}{l}0-5 \\
(0)\end{array}$ & $\begin{array}{r}2-40 \\
(2)\end{array}$ \\
\hline
\end{tabular}

FIGURE 7. $R_{d}$ Estimates $(\mathrm{mL} / \mathrm{g}$ ) for Antimony, Molybdenum, and Sulfide. The numbers in parentheses are conservative $R_{d}$ ranges above them. See Figure 1 for parameter definitions. 


\begin{tabular}{|c|c|c|c|c|}
\hline & \multicolumn{2}{|c|}{ HIGH DISSOLVED SOLIDS } & \multicolumn{2}{|c|}{ LOW DISSOLVED SOLIDS } \\
\hline & HIGH ORGANICS & LOW ORGANICS & HIGH ORGANICS & LOW ORGANICS \\
\hline NEUTRAL & $\begin{array}{l}0-30 \\
(10)\end{array}$ & $\begin{array}{c}20-500 \\
(20)\end{array}$ & $\begin{array}{l}2-20 \\
(10)\end{array}$ & $\begin{array}{c}10-1,000 \\
(40)\end{array}$ \\
\hline & Prout (1959) & & & Rhodes (1957a) \\
\hline ACID & $\begin{array}{r}0-10 \\
(5)\end{array}$ & $\begin{array}{c}10-500 \\
(10)\end{array}$ & $\begin{array}{r}2-20 \\
(5)\end{array}$ & $\begin{array}{c}10-1,000 \\
(20)\end{array}$ \\
\hline & Prout (1959) & & & Rhodes (1957a) \\
\hline
\end{tabular}

FIGURE 8. R $R_{d}$ Estimates $(\mathrm{mL} / \mathrm{g}$ ) for Zirconium, Niobium, and Tin. The numbers in parentheses are conservative $R_{d}$ ranges above them. See Figure 1 for parameter definitions. 


\begin{tabular}{|c|c|c|c|c|}
\hline & \multicolumn{2}{|c|}{ HIGH DISSOLVED SOLIDS } & \multicolumn{2}{|c|}{ LOW DISSOLVED SOLIDS } \\
\hline & HIGH ORGANICS & LOW ORGANICS & HIGH ORGANICS & LOW ORGANICS \\
\hline $\begin{array}{l}\text { NEUTRAL } \\
\text { TO BASIC }\end{array}$ & 0 & $\begin{array}{c}0 \\
\text { Brown and Haney } \\
\text { (1964) } \\
\text { Brown (1967) }\end{array}$ & 0 & $\begin{array}{c}0 \\
\text { Haney (1964) } \\
\text { Wildung et al. (1975) } \\
\text { Routson et al. (1976) }\end{array}$ \\
\hline ACID & 0 & 0 & 0 & 0 \\
\hline
\end{tabular}

FIGURE 9. $R_{d}$ Estimates (mL/g) for Chromium(VI), Tritium, Technetium, Chloride, Fluoride, Iodine, Sulfate, Nitrate, Xenon, Krypton, and Argon. The numbers in parentheses are conservative $R_{d}$ ranges above them. See Figure 1 for parameter definitions. 


\begin{tabular}{|c|c|c|c|c|}
\hline & \multicolumn{2}{|c|}{ HIGH DISSOLVED SOLIDS } & \multicolumn{2}{|c|}{ LOW DISSOLVED SOLIDS } \\
\hline & HIGH ORGANICS & LOW ORGANICS & HIGH ORGANICS & LOW ORGANICS \\
\hline $\begin{array}{l}\text { NEUTRAL } \\
\text { TO BASIC }\end{array}$ & $\begin{array}{c}\begin{array}{c}3-300 \\
(10)\end{array} \\
\text { Barney (1978) }\end{array}$ & $\begin{array}{l}\begin{array}{c}3-300 \\
(10)\end{array} \\
\text { Rhodes and Nelson } \\
(1957) \\
\text { Hajek and Ames (1968) } \\
\text { Routson et al. (1981) }\end{array}$ & $\begin{array}{c}\begin{array}{c}50-3,000 \\
(50)\end{array} \\
\text { Barney (1978) }\end{array}$ & $\begin{array}{l}50-3,000 \\
(50) \\
\text { Rhodes and Nelson } \\
\quad(1957) \\
\text { Hajek and Ames (1968) } \\
\text { Routson et al. (1981) }\end{array}$ \\
\hline ACID & $\begin{array}{c}5-50 \\
(5) \\
\text { Knoll (1969) }\end{array}$ & $\begin{array}{l}5-50 \\
\qquad 5) \\
\text { McHenry (1954) } \\
\text { Rhodes and Nelson } \\
\text { (1957) }\end{array}$ & $\begin{array}{c}10-100 \\
(30)\end{array}$ & $\begin{array}{c}10-100 \\
(30) \\
\text { McHenry (1954) } \\
\text { Rhodes and Nelson } \\
(1957)\end{array}$ \\
\hline
\end{tabular}

FIGURE 10. $R_{d}$ Estimates (mL/g) for Cesium. The numbers in parentheses are conservative $R_{d}$ ranges above them. See Figure 1 for parameter definitions. 


\begin{tabular}{|c|c|c|c|c|}
\cline { 2 - 5 } \multicolumn{1}{c|}{} & \multicolumn{2}{|c|}{ HIGH DISSOLVED SOLIDS } & \multicolumn{2}{c|}{ LOW DISSOLVED SOLIDS } \\
\cline { 2 - 5 } & HIGH ORGANICS & LOW ORGANICS & HIGH ORGANICS & LOW ORGANICS \\
\hline NEUTRAL & $\begin{array}{c}0-10 \\
\text { TO BASIC }\end{array}$ & $\begin{array}{c}10-200 \\
(100)\end{array}$ & $\begin{array}{c}0-20 \\
(5)\end{array}$ & $\begin{array}{c}100-500 \\
(200)\end{array}$ \\
Benson (1960) \\
ACID
\end{tabular}

FIGURE 11. Rd Estimates (mL/g) for Chromium(III), Rare Earths (Ce, La, Eu, Pm), Americium, and Curium. The numbers in parentheses are conservative $R_{d}$ ranges above them. See Figure 1 for parameter definitions. 


\begin{tabular}{|c|c|c|c|c|}
\hline & \multicolumn{2}{|c|}{ HIGH DISSOLVED SOLIDS } & \multicolumn{2}{|c|}{ LOW DISSOLVED SOLIDS } \\
\hline & HIGH ORGANICS & LOW ORGANICS & HIGH ORGANICS & LOW ORGANICS \\
\hline $\begin{array}{l}\text { NEUTRAL } \\
\text { TO BASIC }\end{array}$ & $\begin{array}{c}0.2-20 \\
(10)\end{array}$ & $\begin{array}{c}\begin{array}{c}20-200 \\
(50)\end{array} \\
\text { Rhodes }(1957 \mathrm{~b})\end{array}$ & $\begin{array}{c}0.2-20 \\
(10)\end{array}$ & $\begin{array}{c}100-2,000 \\
(25) \\
\text { Rhodes (1957b) } \\
\text { Emery and Garland } \\
(1974) \\
\text { Emery et al. (1974) }\end{array}$ \\
\hline ACID & $\begin{array}{l}\qquad .1-1.0 \\
(0.5) \\
\text { Benson }(1960) \\
\text { Knoll (1969) }\end{array}$ & $\begin{array}{c}1-20 \\
(5) \\
\text { Hajek and Knoll } \\
(1966)\end{array}$ & $\begin{array}{c}0.1-10 \\
(2)\end{array}$ & $\begin{array}{l}\qquad \begin{array}{c}20-200 \\
(20)\end{array} \\
\text { Rhodes }(1957 \mathrm{~b})\end{array}$ \\
\hline
\end{tabular}

FIGURE 12. $R_{d}$ Estimates $\left(\mathrm{mL} / \mathrm{g}\right.$ ) for Plutonium. The numbers in parentheses are conservative $R_{d}$ ranges above them. See Figure 1 for parameter definitions. 


\begin{tabular}{|c|c|c|c|c|}
\cline { 2 - 5 } \multicolumn{1}{c|}{} & \multicolumn{2}{c|}{ HIGH DISSOLVED SOLIDS } & \multicolumn{2}{c|}{ LOW DISSOLVED SOLIDS } \\
\cline { 2 - 5 } & HIGH ORGANICS & LOW ORGANICS & HIGH ORGANICS & LOW ORGANICS \\
\hline $\begin{array}{c}\text { NEUTRAL } \\
\text { TO BASIC }\end{array}$ & $\begin{array}{c}0.2-20 \\
(1)\end{array}$ & $\begin{array}{c}0.2-200 \\
(0.5)\end{array}$ & $\begin{array}{c}0.2-20 \\
(1)\end{array}$ & $\begin{array}{c}2-2,000 \\
(2)\end{array}$ \\
\hline \multirow{2}{*}{ ACID } & Routson et al. (1976) & $\begin{array}{c}\text { Benson (1961) } \\
\text { Routson et al (1976) } \\
\text { Sheppard et ai. (1976) }\end{array}$ \\
\hline
\end{tabular}

FIGURE 13. $R_{d}$ Estimates $(\mathrm{mL} / \mathrm{g})$ for Neptunium and Uranium. The numbers in parentheses are conservative $R_{d}$ ranges above them. See Figure 1 for parameter definitions. 


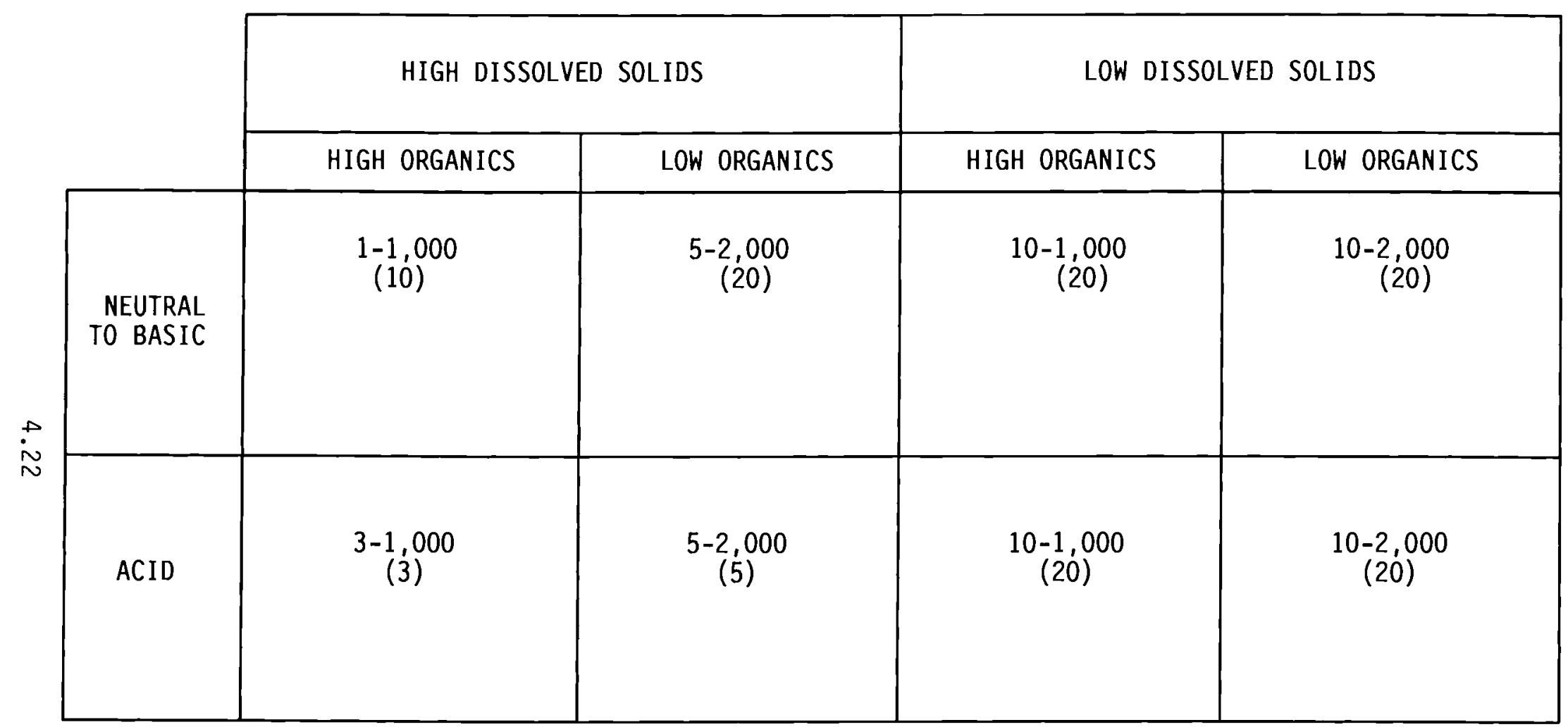

FIGURE 14. Rd Estimates ( $\mathrm{mL} / \mathrm{g}$ ) for Aluminum, Silicon, and Titanium. The numbers in parentheses are conservative $R_{d}$ ranges above them. See Figure 1 for parameter definitions. 


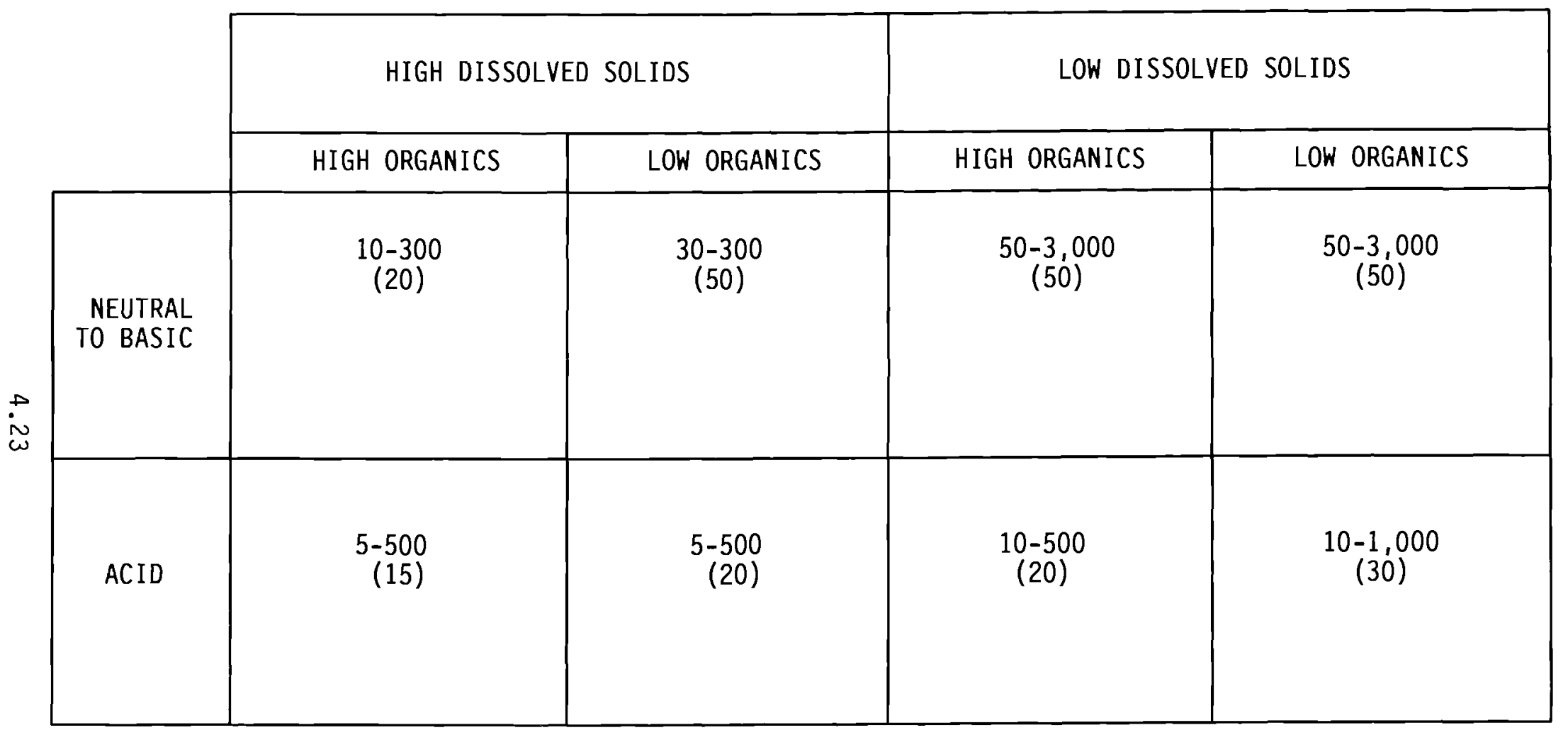

FIGURE 15. $\quad R_{d}$ Estimates $(\mathrm{mL} / \mathrm{g})$ for Phosphate and Vanadium. The numbers in parentheses are conservative $R_{d}$ ranges above them. See Figure 1 for parameter definitions. 


\begin{tabular}{|c|c|c|c|c|}
\hline & \multicolumn{2}{|c|}{ HIGH DISSOLVED SOLIDS(a) } & \multicolumn{2}{|c|}{ LOW DISSOLVED SOLIDS } \\
\hline & HIGH ORGANICS & LOW ORGANICS & HIGH ORGANICS & LOW ORGANICS \\
\hline $\begin{array}{l}\text { NEUTRAL } \\
\text { TO BASIC }\end{array}$ & $\begin{array}{l}\begin{array}{l}0-30 \\
(0)\end{array} \\
\text { Raymond }(1964,1965)\end{array}$ & $\begin{array}{l}\begin{array}{c}0-500 \\
(2)\end{array} \\
\text { Ames and Rai (1978) } \\
\text { Barney (1978) }\end{array}$ & $\begin{array}{r}2-20 \\
(5) \\
\text { Wilding and Rhodes } \\
(1963)\end{array}$ & $\begin{array}{c}10-1,000 \\
(20)\end{array}$ \\
\hline ACID & $\begin{array}{r}0-10 \\
(2)\end{array}$ & $\begin{array}{r}1-500 \\
(50)\end{array}$ & $\begin{array}{l}2-1,000 \\
(20)\end{array}$ & $\begin{array}{l}\begin{array}{c}10-1,000 \\
(40)\end{array} \\
\text { Rhodes (1957a) }\end{array}$ \\
\hline
\end{tabular}

(a) Presence of high nitrates and/or nitrites lowers ruthenium adsorption tendencies; other salts are not important.

FIGURE 16. R Rstimates ( $\mathrm{mL} / \mathrm{g}$ ) for Ruthenium. The numbers in parentheses are conservative $R_{d}$ ranges above them. See Figure 1 for parameter definitions. 
site-specific sediments and the specific waste stream of interest. However, the $R_{d}$ values in the figures provide a conservative estimate that can be used for scoping performance assessment calculations and an estimate of the range in values. If data on a Hanford sediment and liquid waste similar to one of the 33 active discharges are available, the specific reference is cited. Where no citations are given, we relied on experience and general knowledge of contaminant-sediment interactions to develop the estimates (e.g., Coughtrey et a1. 1983-1984; Ames and Rai 1978; Serne and Wood 1990).

\subsection{SOLUBILITY OF INORGANIC AND RADIONUCLIDE CONSTITUENTS}

Solubility (dissolution-precipitation) reactions are often important in controlling the fate of inorganic contaminants that have been disposed of to sediments. Certain constituents are very insoluble with the slightly alkaline $\mathrm{pH}$ and alkaline earth-rich pore waters present in Hanford sediments. Generally oxide, hydroxide, carbonate, and phosphate minerals of certain metallic elements can be expected to control solution concentrations at low values. Some common solubility controls include $\mathrm{Al}$ and $\mathrm{Si}$ oxides; $\mathrm{Pb}$ and $\mathrm{Ca}$ carbonates or phosphates; $\mathrm{Ti}, \mathrm{Cr}, \mathrm{Mn}, \mathrm{Fe}, \mathrm{Zr}, \mathrm{lanthanum,} \mathrm{and} \mathrm{actinide} \mathrm{oxides}$ and hydroxides; and Ba sulfate. Krupka (in Evans et al. 1988b) has discussed solubility calculations for Hanford groundwaters and suggested that many of the elements listed above could be controlled by these minerals under existing conditions in the upper unconfined aquifer. Rai and Serne (1978), Lindsay (1979), Stumm and Morgan (1981), Drever (1982), and Nordstrom and Munoz (1985) have all presented generic discussions of solubility controls in soils and sediments and presented methods to aid researchers in performing such calculations for site-specific conditions. It should be pointed out that a solubility limit is not a constant value in a chemically dynamic system. That is, the solubility limit (e.g., on $\mathrm{Pu}, \mathrm{Sr}, \mathrm{Cd}$, or $\mathrm{Pb}$ ) is determined by the product of the thermodynamic activities of species that constitute the solid. If the system chemistry changes, then the individual species activities will likely change. For example, if the controlling solid for plutonium is the hydrous oxide $\mathrm{Pu}(\mathrm{OH})_{4}$, the solubility product is $[\mathrm{Pu}][\mathrm{OH}]^{4}=\mathrm{K}_{\mathrm{sp}}$, where brackets indicate activities. The value of $k_{s p}$ is fixed, but the values of $[\mathrm{Pu}]$ and $[\mathrm{OH}]$ can vary. In fact, if the $\mathrm{pH}$ decreases 1 unit (meaning that 
$\left[\mathrm{OH}\right.$ ] decreases by 10 ), then for $\mathrm{K}_{\mathrm{Sp}}$ to remain constant, [Pu] must increase by $10^{4}$, with all else held constant. A true solubility model must consider the total system and does not reduce to a fixed value for the concentration of a constituent under all conditions. Numerous constant-concentration (i.e., empirical solubility) models are used in performance assessment activities; such models assume a controlling solid and fix the chemistry of all constituents to derive a fixed value for the concentration of specific contaminants. However, the value obtained is only valid for the specific conditions assumed.

Solubility-controlled release models assume that a known solid is present, or rapidly forms, and controls the solution concentration of the constituents being released. Solubility models are thermodynamic equilibrium models and do not consider kinetics (i.e., the time required for the solid to dissolve or completely precipitate). When identification of the probable controlling solid is difficult or when kinetic constraints are suspected, empirical solubility experiments are often performed to gather data that can be used to generate an empirical solubility release model (a model with mathematical similarity to solubility but no identified thermodynamically acceptable controlling solid).

Currently, two commonly used performance assessment codes, TRANSS and the Multimedia Environmental Pollutant Assessment System (MEPAS), can accommodate only the constant solubility release model. The geochemical code MINTEQ (Felmy et al. 1984; Peterson et al. 1987) is the current detailed solubility model and code used at PNL. Less detailed, constant-concentration-limit models have been generated from empirical studies (Delegard and Gallagher 1983; Delegard et al. 1984).

The active waste streams identified by Westinghouse Hanford (1989) generally have near-neutral to slightly alkaline $\mathrm{pH}$ and low to moderate total dissolved solids contents. On contact between the waste stream and the Hanford sediments, we do not expect any dramatic changes in pH or redox state, two variables that can cause significant dissolution/precipitation reactions. Thus, it is not likely that most contaminants within the liquid waste streams, 
aside from very insoluble constituents (e.g., $\mathrm{Al}, \mathrm{Fe}, \mathrm{Mn}, \mathrm{Am}, \mathrm{Pu}, \mathrm{PO}_{4}$ ), will be controlled by solubility processes.

Another way of looking at the waste streams' fate is that the measurements of the chemical composition available reflect precipitation reactions that have already occurred within the process facilities. That is, highly insoluble constituents are not found in the liquid effluents discharged to Hanford sediments because they have already been removed before reaching the disposal crib. The active waste effluents contain soluble constituents that, in general, will remain soluble in the sediment pore waters.

Qualitative solubility rankings for important inorganic contaminants in Hanford waste streams are provided by Serne and Wood (1990, Appendix A). For convenience, a similar table for the major inorganic and radionuclide constituents identified in active waste streams is provided here (Table 15).

At present, we recommend that preliminary performance assessments assume that solubility effects are incorporated into the $R_{d}$ value used to calculate retardation factors. Therefore, no additional computing provisions other than the $R_{d}$ values presented in Figures 2 through 16 must be made to predict the fate of contaminants.

The organic carbon content of most active waste streams does not appear to be significant and probably would not influence the fate of the identified hazardous inorganics and radionuclides. Only five waste streams contain more than $2 \mathrm{ppm}$ organics (see Figure 1). The organic content of only streams A.5 and A.21 have concentrations of known complexers (e.g., tributylphosphate) that reach the parts per million range. Thus, if more detailed and mechanistic modeling of contaminant migration were required, the available thermodynamic data, codes (i.e., MINTEQ), and waste stream analyses could be used to determine plausible solubility controls for most inorganic and radionuclide constituents in at least 31 of the 33 waste streams. MINTEQ currently contains thermodynamic data for the following components of interest to active disposal of liquid waste: $\mathrm{Li}, \mathrm{B}, \mathrm{C}, \mathrm{NO}_{2}^{-}, \mathrm{NO}_{3}^{-}, \mathrm{NH}_{4}^{+}, \mathrm{F}, \mathrm{Na}, \mathrm{Mg}, \mathrm{Al}$, $\mathrm{Si}, \mathrm{PO}^{3-}, \mathrm{s}^{2-}, \mathrm{SO}_{4}^{2-}, \mathrm{Cl}, \mathrm{K}, \mathrm{Ca}, \mathrm{V}, \mathrm{Cr}, \mathrm{Mn}, \mathrm{Fe}, \mathrm{Co}, \mathrm{Ni}, \mathrm{Cu}, \mathrm{Zn}, \mathrm{As}, \mathrm{Se}, \mathrm{Br}, \mathrm{Rb}$, Sr, Mo, $\mathrm{Ag}, \mathrm{Cd}, \mathrm{Sb}, \mathrm{I}, \mathrm{Sc}, \mathrm{Ba}, \mathrm{Hg}, \mathrm{Tl}, \mathrm{Pb}, \mathrm{Ra}, \mathrm{U}, \mathrm{Am}$, and Pu(III), Pu(IV), $\mathrm{Pu}(\mathrm{V})$, and $\mathrm{Pu}(\mathrm{VI})$. Currently absent from the MINTEQ database are 


\section{TABLE 15. Qualitative Estimate of Mineral Solubility of Hanford Sediment in Pore Water}

\begin{tabular}{|c|c|c|c|}
\hline Constituent & $\begin{array}{c}\text { High Organic } \\
\text { Carbon } \\
\text { Solution } \\
(>2,600 \text { ppb) }\end{array}$ & $\begin{array}{l}\text { Low Organ ic } \\
\text { Carbon } \\
\text { Solution } \\
(\langle 2,000 \text { ppb) }\end{array}$ & Limiting Solid \\
\hline $\mathbf{3}_{\mathrm{H}}$ & vs (a) & vs & -- \\
\hline $\mathrm{Li}$ & vs & vs & -- \\
\hline $\mathrm{Be}$ & Unknown & Unknown & -- \\
\hline $\mathrm{NH}_{4}^{+}$ & VS & VS & -- \\
\hline $\mathrm{NO}_{3}^{4}$ & VS & VS & -- \\
\hline $\mathrm{F}^{\mathrm{J}}$ & MS (b) & MS & $\mathrm{CaF}_{2}$ \\
\hline $\mathrm{Na}$ & vS & VS & $2--$ \\
\hline $\mathrm{Mg}$ & MS $(s)$ & MS & Carbonates \\
\hline$A i$ & $\mathrm{LS}^{(c)}$ & LS & Oxides \\
\hline so & MS & MS & Oxides \\
\hline $\mathrm{PO}_{4}$ & MS & LS & Ca phosphates \\
\hline $\operatorname{sg}_{4}^{4}$ & VS & MS & $\mathrm{CaSO}_{4} \cdot 2 \mathrm{H}_{2} \mathrm{O}$ \\
\hline$s^{23}$ & MS & us & Metal suffides \\
\hline $\mathrm{Cl}$ & VS & VS & -- \\
\hline Ar & MS & MS & -- \\
\hline $\mathbf{k}$ & VS & vS & -- \\
\hline $\mathrm{Ca}$ & MS & MS & Carbonates, phosphates \\
\hline $\mathrm{Ti}$ & LS & LS & Oxides \\
\hline$v$ & MS & WS & -- \\
\hline $\operatorname{Cr}(V I)$ & VS & VS & - \\
\hline $\operatorname{Cr}($ III) & LS & LS & Mixed $\mathrm{Fe}(\mathrm{OH})_{3}$ \\
\hline Mn & us & LS & Oxides, hydroxides \\
\hline $\mathrm{Fe}$ & MS & LS & Oxides, hydroxides \\
\hline Co & WS & US & Hydroxides \\
\hline $\mathrm{Cu}$ & MS & MS & Hydroxides, carbonates \\
\hline $\mathrm{Zn}$ & MS & MS & Hydroxides, carbonates \\
\hline As & vS & vS & -- \\
\hline $\mathrm{Kr}$ & MS & MS & -- \\
\hline $\mathrm{Sr}$ & WS & MS & Carbonates \\
\hline $\mathrm{Zr}$ & MS & LS & Hydroxides, oxides \\
\hline $\mathrm{Nb}$ & MS & LS & Hydroxides, oxides \\
\hline Mo & vs & MS & -- \\
\hline Tc & vs & vS & -- \\
\hline Ru & Unknown & Unknown & -- \\
\hline $\mathrm{Ag}$ & MS & LS & Chlorides \\
\hline$c d$ & MS & US & Carbonates \\
\hline Sn & MS & LS & Hydroxides, oxides \\
\hline Sb & VS & vs & -- \\
\hline $\mathrm{I}$ & MS & us & -- \\
\hline$x_{e}$ & MS & us & -- \\
\hline Cs & vS & vs & -- \\
\hline $\mathrm{Ba}$ & LS & LS & Sulfate \\
\hline Lanthanides & MS & LS & Hydroxides, phosphates \\
\hline $\mathrm{Hg}$ & Unknown & Unknown & -- \\
\hline $\mathrm{Pb}$ & MS & LS & Carbonate-hydroxide mix \\
\hline$U_{N_{n}}$ & MS & MS & Phosphate, oxide, alkaline earth urana \\
\hline $\begin{array}{l}\text { Np } \\
\text { Pu }\end{array}$ & MS & $\begin{array}{l}\text { MS } \\
\text { LS }\end{array}$ & $\begin{array}{l}\text { Hydroxides } \\
\text { Hydroxides }\end{array}$ \\
\hline $\begin{array}{ll}\text { Pu } \\
\text { An }\end{array}$ & MS & LS & $\begin{array}{l}\text { Hydroxides } \\
\text { Hydroxides, phosphates }\end{array}$ \\
\hline
\end{tabular}

(a) VS = Very soluble; common controlling solids in Hanford sediments/waste stream environments (pH between 5.5 and 10.5 ) would allow more than $1,660 \mathrm{mg} / \mathrm{L}$ in solution.

(b) $M S=$ Moderately soluble; common controlling solids in Hanford sedinents/waste strean environments (oH between 5.5 and 16.5 ) would allow no more than $25 \mathrm{mg} / \mathrm{L}$ in solution.

(c) LS = Low solubility; comon controlling solids in Hanford sediments/waste stream environments (pH between 5.5 and 10.5 ) would allow less than $1 \mathrm{ng} / \mathrm{L}$ in solution. 
thermodynamic data for $\mathrm{Be}, \mathrm{Ti}, \mathrm{Zr}, \mathrm{Nb}, \mathrm{Sn}, \mathrm{Tc}, \mathrm{Ru}$, lanthanides, Np, and $\mathrm{Cm}$. Detailed solubility calculations for these neglected components would require an effort to collect data from the literature, critically review the information, and enter the reviewed data into the appropriate data files. Depending on complexity and data quantity, the cost of performing such activities would be between $\$ 20,000$ and $\$ 30,000$ for each element.

\subsection{CHEMICAL/RADIOLOGICAL HALF-LIVES}

Inorganic contaminants found in the active waste streams do not degrade biotically or convert into other constituents and can therefore be considered to remain present forever. Certain nutrients ( $\mathrm{N}$ - and $\mathrm{P}$-containing compounds), such as $\mathrm{NH}_{4}^{+}, \mathrm{NO}_{2}^{-}, \mathrm{NO}_{3}^{-}$, and $\mathrm{PO}_{4}^{-}$, can be transformed by microbiological reactions, but we will not consider such reactions here. Microbiological activity is not currently considered to be significant in Hanford vadose zone sediments. Nitrate plumes from past and current disposal practices are extensive in the Hanford Site's upper unconfined aquifer (see, for example, Evans et a1. 1988a, 1988b, 1989). From this fact we infer that biological degradation of nitrate is not significant and that it is probably not significant for other inorganic nutrients.

All of the radionuclides identified in the 33 active waste streams decay to other elements with a characteristic half-life, as presented in Table 16. For probable scenarios of concern (e.g., liquid disposal to the vadose sediments, percolation to the water table, and subsequent transport in the upper unconfined aquifer to a future domestic drinking water well or the Columbia River), nonreacting nuclides with half-lives longer than 100 years can be considered stable. That is, how long it takes for water to reach the well or river after disposal to the vadose zone sediments is likely to vary between tens of days to many tens of years (e.g., DOE 1987; USGS 1987; Buelt et al. 1988). Mobile contaminants that do not significantly interact with the sediments would reach the well or river in about the same lengths of time as the water. Conversely, contaminants that do interact significantly with the sediments will travel at reduced rates, as quantified by the retardation 
TABLE 16. Half-Life for Radionuclides Identified in Active Waste Streams

\begin{tabular}{|c|c|c|c|}
\hline Isotope & Half-Life, yr & Isotope & Half-Life, yr \\
\hline $3 \mathrm{H}$ & 12.3 & ${ }^{125} \mathrm{Sb}$ & 2.7 \\
\hline${ }^{24} \mathrm{Na}$ & $1.7 \times 10^{-3}$ & ${ }^{129} \mathrm{I}$ & $1.7 \times 10^{+7}$ \\
\hline $32 p$ & $3.9 \times 10^{-2}$ & $131_{I}$ & $2.2 \times 10^{-2}$ \\
\hline $41_{\mathrm{Ar}}$ & $2.1 \times 10^{-4}$ & $132 \mathrm{I}$ & $2.6 \times 10^{-4}$ \\
\hline${ }^{51} \mathrm{Cr}$ & $7.6 \times 10^{-2}$ & ${ }^{133} \mathrm{I}$ & $2.3 \times 10^{-3}$ \\
\hline${ }^{54} \mathrm{Mn}$ & $8.3 \times 10^{-1}$ & ${ }^{135}$ I & $7.6 \times 10^{-4}$ \\
\hline $56_{\mathrm{Mn}}$ & $2.9 \times 10^{-4}$ & ${ }^{135} x e$ & $1.0 \times 10^{-3}$ \\
\hline${ }^{59} \mathrm{Fe}$ & $1.2 \times 10^{-1}$ & ${ }^{134} \mathrm{Cs}$ & 2.0 \\
\hline${ }^{58} \mathrm{Co}$ & $2.0 \times 10^{-1}$ & ${ }^{137} \mathrm{Cs}$ & 30.0 \\
\hline${ }^{60} \mathrm{Co}$ & 5.3 & ${ }^{138} \mathrm{Cs}$ & $6.1 \times 10^{-5}$ \\
\hline $65_{Z n}$ & $6.7 \times 10^{-1}$ & $140_{\mathrm{La}}$ & $4.6 \times 10^{-3}$ \\
\hline $85_{\mathrm{Kr}}$ & 10.8 & ${ }^{140} \mathrm{Ba}$ & $3.5 \times 10^{-2}$ \\
\hline $87_{\mathrm{Kr}}$ & $1.4 \times 10^{-4}$ & ${ }^{141} \mathrm{Ce}$ & $8.9 \times 10^{-2}$ \\
\hline $88_{K r}$ & $3.2 \times 10^{-4}$ & ${ }^{144} \mathrm{Ce}$ & $7.8 \times 10^{-1}$ \\
\hline${ }^{89} \mathrm{sr}$ & $1.4 \times 10^{-1}$ & ${ }^{147} \mathrm{Pm}$ & 2.6 \\
\hline${ }^{90} \mathrm{sr}$ & 27.7 & ${ }^{153} \mathrm{Sm}$ & $5.3 \times 10^{-3}$ \\
\hline $91_{\mathrm{Sr}}$ & $1.1 \times 10^{-3}$ & ${ }^{154} \mathrm{Eu}$ & 16 \\
\hline $95 \mathrm{Zr}$ & $1.8 \times 10^{-1}$ & ${ }^{155} \mathrm{Eu}$ & 1.8 \\
\hline $97 Z r$ & $1.9 \times 10^{-3}$ & $234_{U}$ & $2.5 \times 10^{+5}$ \\
\hline $95_{\mathrm{Nb}}$ & $9.6 \times 10^{-2}$ & $235 U$ & $7.1 \times 10^{+8}$ \\
\hline${ }^{99}$ Mo & $7.6 \times 10^{-3}$ & $236_{U}$ & $2.4 \times 10^{+7}$ \\
\hline${ }^{99} \mathrm{Tc}$ & $2.1 \times 10^{+5}$ & $238_{U}$ & $4.5 \times 10^{+9}$ \\
\hline${ }^{103} \mathrm{Ru}$ & $1.1 \times 10^{-1}$ & ${ }^{239} \mathrm{~Np}$ & $6.4 \times 10^{-3}$ \\
\hline $106_{\mathrm{Ru}}$ & 1.0 & $238 \mathrm{Pu}$ & 86.4 \\
\hline $110 m_{A g}$ & $7.0 \times 10^{-1}$ & ${ }^{239} \mathrm{Pu}$ & $2.4 \times 10^{+4}$ \\
\hline${ }^{113} \mathrm{Sn}$ & $3.0 \times 10^{-1}$ & $241 \mathrm{Pu}$ & 13.2 \\
\hline${ }^{122} \mathrm{Sb}$ & $7.7 \times 10^{-3}$ & ${ }^{244} \mathrm{Am}$ & $1.2 \times 10^{-3}$ \\
\hline${ }^{124} \mathrm{Sb}$ & $1.7 \times 10^{-1}$ & & \\
\hline
\end{tabular}


factor [see Equation (3)]. In such cases, even radionuclides with half-lives as long as thousands of years may in fact decay before reaching the well or river. Performance assessment codes will explicitly consider the decay during transportation of nuclides if one supplies the retardation factor, radionuclide half-life, and water travel time.

Table 16 lists all of the radionuclides identified in the 33 active waste streams. The list is extensive but only a small portion of the radionuclides have half-lives longer than 3 months, an arbitrarily chosen cut-off time for environmental concern for typical Hanford active discharges. Table 17 lists those radionuclides from Table 15 that have half-lives longer than 3 months. The uranium isotopes, ${ }^{129} \mathrm{I}$, and ${ }^{99} \mathrm{Tc}$ have half-lives longer than 100,000 years and for most scenarios germane to active liquid discharges at the Hanford Site, these isotopes will not decay significantly prior to reaching the accessible environment.

\begin{tabular}{|c|c|c|c|}
\hline Isotope & Half-Life, yr & Isotope & Half-Life, yr \\
\hline $238_{U}$ & $4.5 \times 10^{9}$ & ${ }^{60} \mathrm{Co}$ & 5.3 \\
\hline $235 U$ & $7.1 \times 10^{8}$ & ${ }^{125} \mathrm{Sb}$ & 2.7 \\
\hline $236_{U}$ & $2.4 \times 10^{7}$ & ${ }^{147} \mathrm{Pm}$ & 2.6 \\
\hline${ }^{129} \mathrm{I}$ & $1.7 \times 10^{7}$ & ${ }^{134} \mathrm{Cs}$ & 2.0 \\
\hline $234 U$ & $2.5 \times 10^{5}$ & $155_{\mathrm{Eu}}$ & 1.8 \\
\hline${ }^{99} \mathrm{TC}$ & $2.1 \times 10^{5}$ & ${ }^{106} \mathrm{Ru}$ & 1.0 \\
\hline $238 \mathrm{Pu}$ & 86.4 & ${ }^{54} \mathrm{Mn}$ & 0.8 \\
\hline${ }^{137} \mathrm{Cs}$ & 30 & ${ }^{144} \mathrm{Ce}$ & 0.8 \\
\hline${ }^{90} \mathrm{Sr}$ & 27.7 & $62 \mathrm{Zn}$ & 0.7 \\
\hline${ }^{154} \mathrm{Eu}$ & 16 & $110 m_{A g}$ & 0.7 \\
\hline $241 \mathrm{Pu}$ & 13.2 & ${ }^{113} \mathrm{Sn}$ & 0.3 \\
\hline $85 \mathrm{kr}$ & 10.8 & & \\
\hline
\end{tabular}




\subsection{DISTRIBUTION COEFFICIENTS FOR ORGANICS}

The processes affecting migration rates of both organic and inorganic compounds are listed in Table 18. The transformation processes in Table 18 can be graded relative to the properties of a compound, and field data for environmental factors yield a good indication of the compound's persistence in the sediment/water column. Volatilization is an important exchange process that occurs between a compound being dissolved in solution that is vaporized in the atmosphere. Organic compounds with high vapor pressures and low water solubilities are most susceptible to volatilization (for example, aliphatic hydrocarbons, monocyclic aromatics, and some nitrogen-substituted compounds). The magnitude of the Henry's law constant is used as an indicator of compound volatility because it accounts for compound water solubility and vapor

pressure. However, quantitative measurement of compound volatility also must take into account wind velocity, water turbulence, and temperature.

Photolysis is another transformation process that depends on both compound properties and environmental conditions. The degree of photolys is is dependent on the amount of light (energy) a chemical can absorb and the efficiency with which it uses that energy, as well as sunlight intensity, cloud cover, time of day, season, latitude, ozone layer thickness, and water turbidity.

The migration behavior of organic compounds in the environment is primarily a result of the interaction between the physical and chemical properties of the compound and the sorbent. The effect of these properties in the water and sediment column may be subject to changes in such variables as $\mathrm{pH}$, Eh, dissolved organics and inorganics, temperature, and water hydrodynamics. The transformation processes shown in Table 18 are quantified using the parameters shown in Table 19. From knowledge of the values for each parameter, one can rank the importance of the various processes, as shown in Table 20. For some groups, such as halogenated aliphatic hydrocarbons, a single process dominates transformation and fate in most environments. The fates of many organic compounds are more complex and depend on competing processes that vary in importance depending on compound properties and 


\section{TABLE 18. Physical and Chemical Processes Used to Assess the Distribution and Fate of Organic Compounds (Witkowski et al. 1987)}

Process

Volatilization

Sorption

Photolysis

Chemical oxidation

Hydrolysis

Bioaccumulation

Biotransformation and biodegradation
Definition and Controlling Variables

Evaporative loss of a chenical.

Depends on vapor pressure and water solubility of the chemical and on environmental variables such as ind, water turbulence, and tenperature.

Potentially important for compounds with high vapor pressures, low solubilities, and high activity coefficients.

General term encompassing surface attraction (adsorption) and partition (solubilization).

Depends on the hydrophilic and lipophilic properties of the chemical and the composition of the sorbent.

Indicative paraneters are solubility, octanol-water partition coefficient, and sorbent organic carbon content.

Nonmetabolic degradation requiring light energy: chenical undergoes either a direct transformation reaction from the absorbed energy or an indirect change from a reaction (e.g., oxidation) with an excited chenical species or free radical.

Depends on the chenical's absorption spectrun coefficient in the ultraviolet to visible range, as well as the sunlight intensity distribution for a given time of day, season, latitude, depth in water, and ozone thickness. Also depends on the chemical's reaction quantum yield.

Breaking down of the chemical bonds in organic compounds through a chemical reaction with photochenically derived oxidants (single oxygen or free radicals).

Depends on the number and types of possible reactive sites and on the presence of oxidants.

Rate constants either measured directly or estimated from structure-activity relations.

Reaction of a chenical with water, hydrogen, or hydroxide ion, commonly resulting in the introduction of a hydroxyl group in exchange for the removal of another functional group.

Depends on the presence and number of hydrolyzable functional groups at neutral pH plus the catalytic effect of the addition of acids and bases at other pHs.

Uptake and retention of chemicals in the water column by aquatic organisas through intake fron water or diet.

Depends on the nature of the chemical (i.e., if lipophilic) and the organism's fat content and metabolic and depuration rates.

Enzyme-catalyzed transformation of chenicals as a source of energy, carbon, and nutrients.

Depends on the refractory and toxic nature of the chemical and on the presence of an acclimated microbial population and a host of environmental factors, including $\mathrm{pH}_{\text {, }}$ temperature, dissolved oxygen, available nutrients, and conetabolites. 


\section{TABLE 19. Physicochemical Parameters Used in Evaluation}

of Transport Properties of Organic Compounds (Witkowski et al. 1987)

\section{Characteristics}

Water solubility

Vapor pressure

Henry's law constant

Reaeration rate ratio

Partition coefficient (K)

Octanol-water partition coefficient $\left(\mathrm{K}_{\mathrm{O}} / \mathrm{w}\right)$

Soil/sediment partition coefficient (Kp)

So il/sediment organic carbon partition constant $\left(K_{\text {oc }}\right)$

Absorption spectrum coefficient

Reaction quantum yield

Photolysis rate constant

Oxidation rate constant

Hydrolysis rate constant

Bioconcentration factor

Biotransformation rate

\section{Definitions}

Indicative of chemical's hydrophobic/hydrophilic nature, the limiting load in water, and its potential behavior in solution. Units: mass per volume.

The partial pressure of vapor that is in equilibriun with a substance in its impure state at a specified tenperature. Relative or qualitative peasure of the volatility of the chemical in its pure state. Units: mass/length*time ${ }^{2}$ (e.g., pascal, atm).

Relative equilibriun concentration of a compound in a ir and water at standard temperature and pressure. Ratio of the vapor pressure divided by the chemical's water solubility; indicative of the compound's volatility. Units: $a_{m} \bullet^{3} / m_{0} l$.

Ratio of the first-order rate constant for loss of a chemical from aqueous, solution divided by the rate constant for oxygen uptake by the same solution. Unitless. Estimate of the volatility of compounds with Henry's law constants 33,580 torr per nolar for which the volatilization rate constant is limited by diffusion through the liquid-phase boundary layer.

Equilibriun distribution of a conpound solubilized between two immiscible solvents. Unitless (see soil/sediment partition coefficient below).

Equilibriun distribution of a conpound between water and n-octanol. Indicative characteristic of the bioconcentration potential of compounds. Unitless.

Equilibriun distribution of a conpound between water and a sedinent/soil substrate. Mass of chemical per mass of sedinent divided by the dissolved mass of chemical in solution per mass of solution. Unitless.

Soil/sediment partition coefficient divided by the soil/sediment percent organic carbon content. This noralizes the partition coefficient to a soil/sedinent substrate that is 160X organic carbon, permitting comparison of partition coefficients between substrates of differing carbon content. Unitless.

Quantity of light absorbed by the chemical at a particular wavelength in the ultraviolet-visible range of the electromagnetic spectrun.

Efficiency of light utilization by a chemical. Ratio of the number of noles of the chenical transformed to the quantity (flux) of light adsorbed. Unitless.

First-order rate constant for direct photolysis. Units: reciprocal time.

Sun of the rate constants for each individual type of reactive site in the compound. Units: reciprocal time.

First-order rate constant at $\mathrm{pH}$ of 7 and the second-order rate constants for acidand base-promoted hydrolysis. Units: reciprocal time.

Concentration of a chenical in tissue on a dry-weight basis divided by the concentration in water. Also the ratio of the uptake to depuration rates for a compound in a given organisa. Unitless.

Second-order rate constant dependent on the chenical concentration and the microbial bionass. Units: reciprocal tine. 
TABLE 20. Environmental Processes Affecting the Organic Compounds Identified in the 33 Waste Streams (Witkowski et a1. 1987)

\begin{tabular}{|c|c|c|c|}
\hline Chenica I Group & $\begin{array}{l}\text { Primary } \\
\text { Mochanism }\end{array}$ & $\begin{array}{l}\text { Secondary } \\
\text { Mechan ism }\end{array}$ & Conments \\
\hline $\begin{array}{l}\text { Ha logenated a liphat ic } \\
\text { hydrocarbons }\end{array}$ & Volatilization & & $\begin{array}{l}\text { Compounds with more than five } \\
\text { chlorine atoms are sorptive. } \\
\text { Have a potential for bioaccumulation. }\end{array}$ \\
\hline $\begin{array}{l}\text { Halogenated ethers } \\
\text { Aliphatic } \\
\text { Aronatic }\end{array}$ & Sorption & $\begin{array}{l}\text { Volatilization and } \\
\text { photo-oxidation in } \\
\text { atmosphere } \\
\text { Bioaccunulation and } \\
\text { biodegradation }\end{array}$ & $\begin{array}{l}\text { Some persistence due to high } \\
\text { solubility. Also persistence } \\
\text { potential due to lipophilicity. }\end{array}$ \\
\hline Monocyclic aromatics & $\begin{array}{l}\text { Volatilization } \\
\text { Sorption and } \\
\text { bioaccunulation }\end{array}$ & $\begin{array}{l}\text { Atmospheric } \\
\text { oxidation/photolysis } \\
\text { Slow biodegradation } \\
\text { (especially nitrogen } \\
\text { compounds) }\end{array}$ & $\begin{array}{l}\text { Volatilization/sorption are } \\
\text { competing reactions with } \\
\text { environmental conditions } \\
\text { determining which don inates. } \\
\text { Some persistence from high } \\
\text { solubility. }\end{array}$ \\
\hline Phenols & $\begin{array}{l}\text { Photolys is } \\
\text { Biodegradation }\end{array}$ & $\begin{array}{l}\text { (near air-water surface) } \\
\text { (near water sediment if } \\
\text { sufficient icrobes) }\end{array}$ & $\begin{array}{l}\text { No accumulation/persistence } \\
\text { except for nitrophenols, } \\
\text { which sorb readily to clays. }\end{array}$ \\
\hline $\begin{array}{l}\text { Monocyclic aromatics } \\
\text { and phenols with five } \\
\text { or more chlorines }\end{array}$ & $\begin{array}{l}\text { Sorption and } \\
\text { bioaccumulation }\end{array}$ & & $\begin{array}{l}\text { Chlorine content dominates } \\
\text { compound behavior. }\end{array}$ \\
\hline Phthalate esters & Sorption & $\begin{array}{l}\text { Bioaccumulation, } \\
\text { biotransformation, } \\
\text { and biodegradation }\end{array}$ & $\begin{array}{l}\text { Biologically reactive in meta- } \\
\text { bolic processes. Because of } \\
\text { sorption, transport depends } \\
\text { on hydrogeologic conditions. }\end{array}$ \\
\hline $\begin{array}{l}\text { Polynuclear aromatic } \\
\text { hydrocarbons }\end{array}$ & $\begin{array}{l}\text { Sorption, } \\
\text { bioaccumulation, } \\
\text { and biodegradation }\end{array}$ & $\begin{array}{l}\text { Photolys is (for com- } \\
\text { pounds with low ring } \\
\text { numbers) }\end{array}$ & $\begin{array}{l}\text { Bioaccumulation short-term } \\
\text { because readily metabolized. } \\
\text { Sorption increases and bio- } \\
\text { degradation decreases ith } \\
\text { increasing number of } \\
\text { benzene rings. }\end{array}$ \\
\hline $\begin{array}{l}\text { Nitrogen compounds } \\
\text { Aliphatic } \\
\text { Aromatic }\end{array}$ & $\begin{array}{l}\text { Photolysis } \\
\text { Sorption }\end{array}$ & Biodegradation & $\begin{array}{l}\text { Mainly hydrospheric photolysis } \\
\text { due to high solubility but } \\
\text { also atmospheric. }\end{array}$ \\
\hline
\end{tabular}


prevailing environmental conditions. For example, monocyclic aromatics are susceptible to either volatilization followed by atmospheric photolysis or sorption followed by bioaccumulation. In this example, the transformation processes that control compound persistence vary with environmental factors, such as wind speed, temperature, and availability of particulates in the water column for sorption.

The presence of solvents other than water can alter an organic compound's water solubility. Hence, the presence of cosolutes must be considered when attempting to predict the transport of organic contaminants through the subsurface. In general, sediment contaminated with low-water-solubility organics tend to bind other organics to the organic carbon fraction of the sediment. However, if existing sorbed organics are contacted by other lowwater-solubility (i.e., hydrophobic) organics (cosolvents), the sorbed organics may be mobilized in the cosolvents.

Data on transformation of organic compounds (e.g., biological degradation) in water and sediments are available in many cases but are not very useful in predicting contaminant fate at the Hanford Site because of the numerous uncertainties derived from the influences of many environmental factors on transformation or degradation rates. These environmental factors include the presence, number, and species of organisms in the sediments, sediment $\mathrm{pH}$, sediment type, moisture content, and temperature of the environment. Degradation rates or organic compound half-lives tend to be specific for a given environment and often cover a wide range of values for a single organic. Because the bulk of the half-lives given in the literature lack applicability to the Hanford Site, the values listed in Appendix A should not be given much credence because none were obtained in environments specific to the Hanford Site. Rather, the half-life information should be considered as qualitative guidance.

The soil/sediment partition coefficient, $K p$, is defined as the ratio of adsorbed organic chemical per unit weight of the sediment to the weight of the aqueous solute per the same unit weight of solution. $\mathrm{Kp}$ is unitless. The $\mathrm{K}_{\mathrm{oc}}$, or partition constant, used to compare organic compound sorption of soils 
or sediments with varying organic content is defined as

$$
K_{o c}=\frac{K p}{f o c} \text { or } \frac{(100)(K p)}{\% \text { foc }}
$$

where $f_{o c}$ is the fractional mass of organic carbon in the soil or sediment. In fact, $R_{d}$ values for organics are equivalent to $\left(K_{o c} \bullet f_{o c}\right) / \rho_{b}$ where $f_{o c}=$ fractional weight of naturally occurring organic carbon in the sediment $(0.001$ for typical Hanford sediments) and $\rho_{b}$ is the sediment bulk density $(1.5 \pm 0.3$ $\mathrm{g} / \mathrm{cm}^{3}$ for most Hanford sediments). Organic compounds that bind strongly to organic carbon have characteristically low water solubilities. Likewise, organic compounds with little tendency to sorb onto organic carbon have high water solubilities. Organics that do sorb onto organic materials, if they are present in an aquifer, are retarded in their movement in respect to the groundwater.

If the $K_{o c}$ of a compound is known, the unitless retardation factor $(R)$ can be calculated using Equation (3). The $R_{d}$ in Equation (3) is related to $K_{o c}$ by the equation

$$
K_{o c}=\frac{R_{d} \rho_{b}}{f_{o c}}
$$

For many compounds (Farmer 1976), a linear relationship between the amount sorbed $\left(C_{s}\right)$ and the concentration of the compound in the equilibrium solution $\left(C_{W}\right)$ has been demonstrated: $C_{S}=K p \cdot C_{W}$, where $\mathrm{Kp}$ is the linear partition coefficient. It is equivalent to a Freundlich constant $\left(R_{d}\right)$ when $1 / \mathrm{n}$ equals unity: $C_{s}=R_{d} \bullet C_{W} 1 / n$.

The $K_{0} / w$ of an organic solute is the $n$-octanol/water partition coefficient and defined as the equilibrium ratio of the solute concentration in the water-saturated $n$-octanol phase to the solute concentration in the $n$-octanol-saturated water phase. $\mathrm{K}_{\mathrm{o} / \mathrm{w}}$ values are unitless. For ionizable organic compounds (acids, amines, and phenols), $\mathrm{K}_{\mathrm{O} / \mathrm{w}}$ values are a function of $\mathrm{pH}$. If a $\mathrm{K}_{\mathrm{o} / \mathrm{w}}$ value is reported for an ionizable compound, the $\mathrm{pH}$ also should be reported (see Means et a1. 1982). For sorption based on organic carbon $\left(K_{\mathrm{oc}}\right)$, Karickhoff et al. (1979) reported a significant correlation between the 
adsorption of several aromatic hydrocarbons and the partitioning of the aromatic hydrocarbons between octanol and water $\left(\mathrm{K}_{\mathrm{o} / \mathrm{w}}\right)$

$$
\log K_{O C}=1.00 \log K_{o / w}-0.21\left(R^{2}=1.00\right)
$$

where $R^{2}$ is the least-squares linear regression coefficient of determination. Linear least-squares fitting of the $\mathrm{K}_{\mathrm{o}} / \mathrm{w}$ and $\mathrm{K}_{\mathrm{oc}}$ data from a series of polycyclic aromatics and chlorinated hydrocarbons ranging in water solubility from $1 \mathrm{ppb}$ to $1,000 \mathrm{ppm}$ gave the equation $\mathrm{K}_{\mathrm{oc}}=0.63 \mathrm{~K}_{\mathrm{o} / \mathrm{w}}\left(\mathrm{R}^{2}=0.96\right)$. Other similar regression equations found in the literature and used to estimate $K_{o c}$ values where none were available are listed in Table 21. Unfortunately, as Means et al. (1982) point out, these relationships are applicable only to hydrophobic, nonionizable organic compounds and to sediments containing more than 1 wt\% organic carbon content. As can be seen from the organic carbon contents listed in Table 11, Hanford sediments are very low in organic carbon, generally containing less than $0.10 \mathrm{wt} \%$. Hence these $\mathrm{K}_{\mathrm{o} / \mathrm{w}}$ and $\mathrm{K}_{\mathrm{oc}}$ relationships are not applicable to Hanford conditions except as a tool for very roughly estimating one when the other is known.

The Henry's law constant, sometimes referred to as the air-water partition coefficient, is defined as the ratio of the partial pressure of a compound in air to the concentration of the compound in water under equilibrium conditions. If the vapor pressure and water solubility of a compound are known, the Henry's law constant can be calculated at $1 \mathrm{~atm}$ $(760 \mathrm{~mm} \mathrm{Hg}$ ) as

$$
H=\frac{(P)(S)}{(760)(F W)}
$$

where $H=$ Henry's law constant $\left(a t m \bullet m^{3} / m o l\right)$

$$
\begin{aligned}
\mathrm{P} & =\text { vapor pressure of the compound }\left(\mathrm{mm} \mathrm{Hg} \text { at } 25^{\circ} \mathrm{C}\right) \\
\mathrm{S} & =\text { water solubility }(\mathrm{g} / \mathrm{L}) \\
\mathrm{FW} & =\text { formula weight of the compound }(\mathrm{g} / \mathrm{mol}) .
\end{aligned}
$$


TABLE 21. Regression Equations Useful for Estimation of Partition Coefficients (Koci Witkowski et al. 1987)

\begin{tabular}{|c|c|c|c|c|c|}
\hline Regression equation $(a)$ & $\begin{array}{l}\text { Number of } \\
\text { Compounds }\end{array}$ & $R^{2(b)}$ & $\begin{array}{l}\text { Units for } \\
\text { Solubility }\end{array}$ & $\begin{array}{l}\text { Compound } \\
\text { Groups }\end{array}$ & References \\
\hline $\log K_{0 / w}=-8.747 \log S+0.73 \theta$ & 156 & 0.874 & $\begin{array}{l}\text { Moles per } \\
\text { liter }\end{array}$ & $\begin{array}{l}\text { Low-molecular- } \\
\text { weight organics }\end{array}$ & $\begin{array}{l}\text { Hansch et al. } \\
(1968)\end{array}$ \\
\hline $\log K_{0 / w}=-8.67 \theta \log S+5.00$ & 33 & 0.970 & $\begin{array}{l}\text { Micromoles } \\
\text { per liter }\end{array}$ & $\begin{array}{l}\text { Pesticides and } \\
\text { polychlorinated } \\
\text { biphenyls }\end{array}$ & $\begin{array}{l}\text { Chiou et al. } \\
\text { (1977) }\end{array}$ \\
\hline $\log K_{\text {of }}=-\theta .557 \log S+4.04 \theta$ & 15 & 0.988 & $\begin{array}{l}\text { Micromoles } \\
\text { per liter }\end{array}$ & $\begin{array}{l}\text { Pesticides and } \\
\text { hydrocarbons }\end{array}$ & $\begin{array}{l}\text { Chiou et al. } \\
\text { (1979) }\end{array}$ \\
\hline $\log K_{o c}=-0.54 \log s+0.44$ & 10 & 0.940 & $\begin{array}{l}\text { Mole } \\
\text { fraction }\end{array}$ & $\begin{array}{l}\text { Chlorinated } \\
\text { hydrocarbons }\end{array}$ & $\begin{array}{l}\text { Karickhoff et al. } \\
\text { (1979) }\end{array}$ \\
\hline $\log K_{o c}=-6.686 \log S+4.273$ & 22 & 0.933 & $\begin{array}{l}\text { Micrograms } \\
\text { per liter }\end{array}$ & PAHs & $\begin{array}{l}\text { Means et al. } \\
\text { (1988b) }\end{array}$ \\
\hline $\log K_{o c}=-6.594 \log S+0.197$ & 5 & 8.945 & $\begin{array}{l}\text { Nole } \\
\text { fraction }\end{array}$ & PAHs & $\begin{array}{l}\text { Karickhoff } \\
\text { (1981) }\end{array}$ \\
\hline $\log K_{o c}=-6.83 \log s+0.93-0.61(\mathrm{MP}-25)(c)$ & 47 & 0.93 & $\begin{array}{l}\text { Mole } \\
\text { fraction }\end{array}$ & $\begin{array}{l}\text { Chlorinated } \\
\text { hydrocarbons }\end{array}$ & $\begin{array}{l}\text { Karickhoff } \\
(1984)\end{array}$ \\
\hline $\log K_{o c}=1.00 \log K_{o / w}-0.21$ & 10 & 1.00 & $N A(d)$ & $\begin{array}{l}\text { Chlorinated } \\
\text { hydrocarbons }\end{array}$ & $\begin{array}{l}\text { Karickhoff et al. } \\
\text { (1979) }\end{array}$ \\
\hline $\log K_{o c}=1.80 \log K_{o / w}-0.317$ & 22 & 0.98 & $\mathrm{NA}$ & PAHs & $\begin{array}{l}\text { Means et } a 1 \\
(1986 b)\end{array}$ \\
\hline $\log K_{o c}=0.72 \log K_{o / w}-0.49$ & 13 & 8.95 & $\mathrm{NA}$ & $\begin{array}{l}\text { Substituted } \\
\text { hydrocarbons }\end{array}$ & $\begin{array}{l}\text { Schwarzenbach } \\
\text { and Westall (1981) }\end{array}$ \\
\hline $\log K_{o c}=0.937 \theta \log K_{o / w}-0.066$ & 9 & 0.95 & NA & Herbicides & $\begin{array}{l}\text { Brown and } F \text { lagg } \\
(1981)\end{array}$ \\
\hline $\log K_{o c}=0.989 \log K_{o / w}-0.346$ & 5 & 0.997 & $\mathrm{NA}$ & PAHs & $\begin{array}{l}\text { Karickhoff } \\
\text { (1981) }\end{array}$ \\
\hline $\log K_{o c}=1.829 \log K_{o / w}-0.18$ & 13 & 0.91 & NA & Pesticides & $\begin{array}{l}\text { Karickhoff } \\
(1984)\end{array}$ \\
\hline
\end{tabular}

(a) $\mathrm{S}=$ water solubility of the organic solute.

$\mathrm{Ko} / \mathrm{w}=$ octanol-water partition coefficient. Unitless.

Koc = measured partition coefficient/organic carbon content of soil or sediment sample. Unitless. Organic matter, depending on composition, contains about $58 \%$ organic carbon (Hamaker and Thompson 1972) and consequently $\mathrm{K}_{\mathrm{OC}}=1.72 \mathrm{Kom}$.

Kom = measured partition coefficient/organic matter content of soil or sediment sample. Unitless.

(b) The linear regression coefficient of determination.

(c) The last term in this equation compensates for melting-point effects that occur in the phase transition of organic compounds that are initially solids.

(d) $N A=$ Not applicable 
According to Lyman et al. (1982), if $\mathrm{H}$ is less then $10^{-7} \mathrm{~atm} \bullet \mathrm{m}^{3} / \mathrm{mol}$, the substance has low volatility. If $H$ is greater than $10^{-7}$ but less than $10^{-5} \mathrm{~atm} \cdot \mathrm{m}^{3} / \mathrm{mol}$, the substance will volatilize slowly. Volatilization becomes an important transfer mechanism when $H$ is between $10^{-5}$ and $10^{-3} \mathrm{~atm} \cdot \mathrm{m}^{3} / \mathrm{mol}$. When $H$ is larger than $10^{-3} \mathrm{~atm} \bullet \mathrm{m}^{3} / \mathrm{mol}$, volatilization becomes a principal transfer mechanism. Estimating the Henry's law constant for many compounds assumes that the gas phase obeys the ideal gas law and that the aqueous solution acts as an ideal dilute solution. Neither of these assumptions always holds. In addition, the solubility and vapor pressure data used in Equation (8) are generally obtained from the pure substances. Many of the contaminants are not derived from pure substances, and vapor pressure and solubility data are often obtained without regard to standard states and temperatures. Therefore, many of the Henry's law constants given in Appendix $A$ are actually only crude estimates.

The data presented in Appendix $A$ on adsorption parameters, Henry's law constants, water solubilities, and degradation rates for the organic chemicals were mainly obtained from two computer databases. The two databases are the Soil Transport and Fate Database available from Utah State University's Department of Civil and Environmental Engineering (Sims et al. 1988) and Syracuse Research Corporation's Environmental Fate Data Base (EFDB), as described by Howard et al. (1986).

Appendix A presents Freundlich adsorption constants for some organic substances. Like the half-life data, these are closely tied to the conditions under which they were obtained (e.g., soil type, temperature, solution composition). These constants are listed when available, but the conditions under which they were obtained must be examined before their applicability to Hanford conditions can be judged.

Little, if any, data were available for several of the organic compounds in Appendix A. In fact, for a few compounds, we could not even identify a Chemical Abstracts Service Registry Number (CAS No.). The available data describing physical properties were included when no specific adsorption and solubility data are presented for a given constituent. When no values are 
present, the reader may assume that we were unable to find any information in the literature.

In Tables 22 and 23, we summarize the adsorption, water solubility, volatilization (Henry's law constants), and degradation tendencies from Appendix A for those organic compounds identified in Table 5 . When no data were found in the literature, we have estimated qualitatively whether the compound would exhibit high, medium, or low adsorption, water solubility, volatility, or degradation rates in Hanford sediments containing a solution representative of the 33 active waste streams. The qualitative rankings for all the organics identified in Table 5 are shown in Table 23 . This table will allow scoping performance assessment activities to evaluate those compounds that have greater mobility.

Based on the organic data (especially $k_{o c}$ values) given in Appendix $A, R_{d}$ values were estimated for the most prevalent organic analytes, assuming a 0.1 wt $\%$ content of organic carbon for Hanford sediment and a bulk density of $1.5 \mathrm{~g} / \mathrm{cm}^{3}$. The results are shown in Table 22 . The $R_{d}$ data are given only to show trends. As mentioned previously, $R_{d}$ values computed from $K_{o c}$ values for soils containing less than $1.0 \mathrm{wt} \%$ organic carbon are speculative. 
TABLE 22. Available Physicochemical Data for the Organic Compounds Listed in Table 5 . An $R_{d}$ was determined assuming an $f_{0 c}$ of 0.1 wt carbon. The relationship utilized for determination of an $R_{d}$ value was $\left(K_{o c}\right)\left(f_{o c}\right) / \rho_{b}=R_{d}$. For details and references, see Appendix $A$.

\begin{tabular}{|c|c|c|c|c|c|c|}
\hline Organic Compound & Water Solubility at $25^{\circ} \mathrm{C}$ & $\begin{array}{c}\text { Henry's Lay } \\
\text { Constant, atm }{ }^{3} m^{3} / \mathrm{mol} \\
\text { at } 25^{\circ} \mathrm{C}\end{array}$ & $k_{0 / w}$ & $k_{\text {oc }}$ & $\begin{array}{l}\text { Estimated } \\
R_{d, ~} \mathrm{~L} / \mathrm{g}\end{array}$ & $\begin{array}{l}\text { Dissociation } \\
\text { Constants, } \\
\text { Acids and Bases }\end{array}$ \\
\hline Tributy /phosphate & $280 \cdot \mathrm{g} / \mathrm{L}$ & $1.9 \times 10^{-2}$ & $1 \times 10^{3}$ & $6 \times 10^{3}$ & 4 & \\
\hline Tridecane & $1 \times 10^{-3} \mathrm{mg} / \mathrm{L}$ & $N A^{(b)}$ & $4.5 \times 10^{6}$ & $2.8 \times 10^{6}$ & $2.0 \times 10^{3}$ & \\
\hline Tetradecane & 0.3 to $7 \times 10^{-3} \mathrm{gg} / \mathrm{L}$ & 0.3 to 1.2 & $1.6 \times 10^{7}$ & $1.61 \times 10^{7}$ & $6.7 \times 10^{3}$ & \\
\hline Dodecane & 3 to $8 \times 10^{-3} \mathrm{mg} / \mathrm{L}$ & $7.5 \pm 2.5$ & $1.0 \times 10^{6}$ & $6.3 \times 10^{5}$ & $4.6 \times 10^{2}$ & \\
\hline Pentadecane & $7 \times 10^{-5} \mathrm{mg} / \mathrm{L}$ & NA & $5.2 \times 10^{7}$ & $3.28 \times 10^{7}$ & $2.0 \times 10^{4}$ & \\
\hline Tetrachloroethylene & $200 \mathrm{mg} / \mathrm{L}$ & $1.84 \times 10^{2}$ & 460 to 2,560 & 238 to 1,606 & b. 1 to 1 & \\
\hline Chloroform & $7.95 \mathrm{~g} / \mathrm{L}$ & $3.67 \times 10^{-3}$ & 93 & 45 & 6.03 & \\
\hline Bis(2-ethylhexyI) phthalate & $0.46 \mathrm{mg} / \mathrm{L}$ & $1.47 \times 10^{-5}$ & 4,170 to 12,800 & 87,000 & 58 & \\
\hline Undecane & 1 to $4 \times 10^{-2} \mathrm{mg} / \mathrm{L}$ & $1.8 \pm 0.8$ & 0.4 to $5.5 \times 10^{6}$ & $\begin{array}{l}2.5 \times 10^{5} \text { to } \\
3.5 \times 10^{6}\end{array}$ & 200 to 2,000 & \\
\hline 2-butoxyethanol & $45 \mathrm{~g} / \mathrm{L}$ & $2.8 \times 10^{-7}$ & 6.76 & 67 & 0.85 & \\
\hline Butyl alcohol & $74 \mathrm{~g} / \mathrm{L}$ & $8.81 \times 10^{-6}$ & NA & 72 & 0.85 & \\
\hline Acetone & Miscible & $3.88 \times 10^{-5}$ & 0.575 & 18 & 0.67 & \\
\hline Hexadecane & 0.02 to $6.3 \times 10^{-3} \mathrm{mg} / \mathrm{L}$ & 6.3 to $2.3 \times 10^{-1}$ & $1.8 \times 10^{8}$ & $1.13 \times 10^{8}$ & $6 \times 10^{4}$ & \\
\hline Dimethoxymethane ${ }^{(d)}$ & & & & & & \\
\hline Heptadecane & $6 \times 10^{-6} \mathrm{mg} / \mathrm{L}$ & NA & 0.6 to $2.1 \times 10^{9}$ & $\begin{array}{l}3.8 \times 10^{8} \text { to } \\
1.3 \times 10^{9}\end{array}$ & 2.6 to $7 \times 10^{5}$ & \\
\hline Octadecane & 2 to $6 \times 10^{-3} \mathrm{mg} / \mathrm{L}$ & NA & $6.17 \times 10^{8}$ & $3.9 \times 10^{8}$ & $2.6 \times 10^{5}$ & \\
\hline Decane & 2 to $5 \times 10^{-2} \mathrm{mg} / \mathrm{L}$ & $7 \pm 3$ & $1.0 \times 10^{5}$ & $6.3 \times 10^{4}$ & 40 & \\
\hline Methyl formate $(e)$ & $170 \mathrm{~g} / \mathrm{L}$ & $9.12 \times 10^{-3}$ & & & & \\
\hline Phenol & $82.8 \mathrm{~g} / \mathrm{L}$ & $3.33 \times 10^{-7}$ & 28.84 & 38.8 & 6.62 & 10 \\
\hline$N$-methoxymethanam ine ${ }^{(f)}$ & & & & & & \\
\hline Di-n-buty lphthalate & $11.2 \mathrm{mg} / \mathrm{L}$ & $2.8 \times 10^{-7}$ & 758 to 52,490 & 170,000 & 110 & \\
\hline Benzyl alcohol & $40 \mathrm{~g} / \mathrm{L}$ & NA & 12.30 & 95.5 & 6.66 & \\
\hline Methylene chloride & $13.7 \mathrm{~g} / \mathrm{L}$ & $2.19 \times 10^{-3}$ & 17.38 & 28 & 6.82 & \\
\hline Di-n-octylphthalate & $3.0 \mathrm{mg} / \mathrm{L}$ & $4.45 \times 10^{-7}$ & $7.4 \times 10^{9}$ & $3.6 \times 10^{9}$ & $2 \times 10^{6}$ & \\
\hline Benzoic acid & $3.4 \mathrm{~g} / \mathrm{L}$ & $0.287 \times 10^{-5}$ & 74.13 & 182 & 0.006 & 4.265 \\
\hline Methy| ethy| ketone & $223 \mathrm{~g} / \mathrm{L}$ & $5.59 \times 10^{-5}$ & 1.67 & 5.2 & 0.003 & \\
\hline Butylbenzyl phthalate & $2.69 \mathrm{mg} / \mathrm{L}$ & $1.26 \times 10^{-6}$ & 81,280 & 17,860 & 11 & \\
\hline
\end{tabular}


TABLE 22. (cont'd)

Henry's Law

Constant, at $\bullet^{3} / \mathrm{mol}$

at $25^{\circ} \mathrm{C}$

Water Solubility at $25 \propto$

2-methyl-5-propy Inonane ${ }^{(f)}$

Pelargic acid $(g)$

Tetrahydrofuran

Butoxyglycol

Methy | n-butyl ketone

Butyraldehyde

2-propanol

MIBK (hexone)

Methyl n-propyl ketone

Butylnitrate

Ethoxytriethylene glycol

3,5-dimethylpyridine

Ethyl alcohol

$\rightarrow$ Hexadecanoic acid

$\stackrel{\omega}{\omega}$ Acetophenone

Benzaldehyde

Butoxydiglycol

Dichlor of luoromethane

Dimethylnitrosanine

Methoxydiglycol

Methoxytriglycol

2-methylnonane

Norpholine

Phenanthrene

Miscible
Miscible
$17.5 \mathrm{~g} / \mathrm{L}$
$71 \mathrm{~g} / \mathrm{L}$
Miscible
$19 \mathrm{~g} / \mathrm{L}$
$43 \mathrm{~g} / \mathrm{L}$
Low
High
$9.5 \%(W / W)$
Miscible
Insoluble
$6.13 \mathrm{~g} / \mathrm{L}$
$3 \mathrm{~g} / \mathrm{L}$
Miscible
Low
Miscible
Miscible
Miscible
$0.074 \mathrm{mg} / \mathrm{L}$
Miscible
1.15 mg/L

\section{NA}

$2.68 \times 10^{-7}$

$1.1 \times 10^{-5}$

$1.15 \times 10^{-4}$

$7.89 \times 10^{-6}$

$4.2 \times 10^{-5}$

$6.36 \times 10^{-5}$

MA

Low

Medium

$1.2 \times 10^{-5}$

NA

$1.07 \times 10^{-5}$

Medium

Low

High

$2.63 \times 10^{-7}$

Low

Low

NA

$1.44 \times 10^{-7}$

$2.28 \times 10^{-5}$
Estiuated

$\underline{K_{0 / w}} \quad \underline{K_{o c}} \quad \underline{R_{d}, m L / g^{(a)}}$

Dissociation

Constants,

Acids and Bases

(a) Assumed $f_{o c}=0.1$ wt $O C$ and $\rho_{b}=1.5 \mathrm{~g} / \mathrm{cm}^{3}$

(b) $\mathrm{NA}=$ Not acrailable.

(c) Slightly water soluble; explosive vapor at room temperature; density $=1.2075$ (air $=1$ ); melting point $=82.3^{\circ} \mathrm{C}$; boiling point (explosive) $=64.6^{\circ} \mathrm{C}$

(d) Moderately water soluble, colorless gas; flammable; density $=1.617$ (air $=1$ ); one volume of water dissolves 37 volumes of gas; flash point $=-41 \%$ C.

(e) Colorless, flammable l iquid; flash point, closed cup $=-19^{\circ} \mathrm{C}$; density at $15^{\circ} \mathrm{C}=0.987$

(f) Compound not found in literature.

(g) Compound not found in literature; probably pelargonic acid, for which no environmental chacterization data are available.

Very low

0.045

0.01

0.006

0.816

0.013

Very low

Ledium Low

Low Low

Medius Low

$0.30 \quad 0.002$

High Mediun

23-45 0.015-8.03

Mediun Low

Low Very low

NA Low

120.01

Low Very low

Low Very low

High High

Very low Very low

$230,000 \quad 150$ 
TABLE 23. Qualitative Ranking of Geochemical Attributes of the Organic Compounds Listed in Table 5.

\begin{tabular}{|c|c|c|c|c|c|}
\hline \multirow[b]{2}{*}{ Organic Compound } & \multirow[b]{2}{*}{ Conment } & \multicolumn{4}{|c|}{ Qualitative Estimate of } \\
\hline & & Solubility(a) & Volatility $(\mathrm{b})$ & Sorption $(c)$ & Degradation \\
\hline Tributy/phosphate & Readily degrades, $t 1 / 2=6$ days in river water & Medium & High & Medium & Medium \\
\hline Tridecane & Sorbed on sediment clays and organic carbon & Low & High & High & Medium \\
\hline Tetradecane & Sorbed on sediment clays and organic carbon & Low & High & High & Med i un \\
\hline Dodecane & Sorbed on sediment clays and organic carbon & Low & High & High & High \\
\hline Pentadecane & Sorbed on sediment clays and organic carbon & Low & High & High & Medium \\
\hline Tetrachloroethylene & Little sorption & Mediun & High & Low & Low \\
\hline Chloroform & Little sorption & High & Medium & Low & Low \\
\hline Bis (2'ethylhexyl) phthalate & Sorbed on sediment $\mathrm{clays}$ and organic carbon & Medium & Low & High & Medium \\
\hline Undecane & Sorbed on sediment $c$ lays and organic carbon & Low & High & High & Medium \\
\hline 2-butoxyethanol & Little sorption & High & Low & Low & Medium \\
\hline Butyl alcohol & Little sorption & High & Low & Low & Medium \\
\hline Acetone & Little sorption & High & Low & Low & High \\
\hline Hexadecane & Sorbed on sediment clays and organic carbon & Low & High & High & Medium \\
\hline Methy I nitrate & No literature available & Mediun & High & Low & Low \\
\hline Dimethoxymethane & No literature available & Mediun & High & Low & Low \\
\hline Heptadecane & Sorbed on sediment clays and organic carbon & Low & High & High & Medium \\
\hline Octadecane & Sorbed on sediment clays and organic carbon & Low & High & High & Medium \\
\hline Decane & Sorbed on sediment clays and organic carbon & Low & High & Medium & Medium \\
\hline Methyl formate & No I iterature available & High & High & Low & Low \\
\hline Phenol & Sorption a function of $\mathrm{pH}$ & High & Low & Low & Mediun \\
\hline N-methoxymethanam ine & No compound with this structure in literature & $\ldots(d)$ & -- & -- & -- \\
\hline Di-n-butylphthalate & Sorbed on sediment clays and organic carbon & Mediun & Low & High & Medium \\
\hline Benzyl alcohol & Little sorption & High & Low & Low & Mediun \\
\hline Methylene chloride & Little sorption & High & Medium & Low & Medium \\
\hline Di-n-octylphthal ate & Sorbed on sediment organic carbon & Medium & Low & High & Medium \\
\hline Benzoic acid & Sorption a function of $\mathrm{pH}$ & High & Low & Low & Low \\
\hline Methylethyl ketone & Little sorption & High & Low & Low & High \\
\hline Butylbenzyl phthalate & Sorbed on sediment organic carbon & Mediug & Low & Medium & High \\
\hline 2-wethy|-5-propy Inonane & No compound with this structure in literature & -- & -- & -- & -- \\
\hline Pelargic acid & No literature available & -- & -- & -- & -- \\
\hline
\end{tabular}


TABLE 23. (cont'd)

\begin{tabular}{l}
\multicolumn{1}{c}{ Organic Compound } \\
Tetrahydrofuran \\
Butoxyglycol \\
Methyl n-butyl ketone \\
Butyraldehyde \\
2-propanol \\
MIBK (hexone) \\
Methyl n-propyl ketone \\
Butylnitrate \\
Ethoxytriethylene glycol \\
3,5-dinethylpyridine \\
Ethyl alcohol \\
Hexadecanoic acid \\
Acetophenone \\
Benzaldehyde \\
Butoxydiglycol \\
Dichlorofluoromethane \\
Dimethylnitrosanine \\
Methoxydiglycol \\
Methoxytriglycol \\
2-methylnonane \\
Morpholine \\
Phenanthrene \\
of \\
\end{tabular}

Comment
Little sorption
Little sorption on organic carbon; some clay sorption
Little sorption
Little sorption
Little sorption
Little sorption
Little sorption
Little sorption
Little sorption on organic carbon; some clay sorption
Little sorption; odor of pyridine and peppermint
Little sorption
Sorption a function of pH; ordinarily a solid
Little sorption
Little sorption
Little sorption on organic carbon; some clay sorption
Little sorption
Little sorption
Little sorption on organic carbon; some clay sorption
Little sorption on organic carbon; some clay sorption
Good sorption
Little sorption
Good sorption

\begin{tabular}{|c|c|c|c|}
\hline \multicolumn{4}{|c|}{ Qualitative estimate of } \\
\hline Solubility & Volatility & Sorption & Degradation \\
\hline High & High & Low & Low \\
\hline High & Low & Low & Mediun \\
\hline High & Mediun & Low & Low \\
\hline High & Medium & Low & Mediun \\
\hline High & Medium & Low & Low \\
\hline High & Mediun & Low & Mediun \\
\hline High & Mediun & Low & Mediun \\
\hline High & Mediun & Low & Low \\
\hline High & Low & Low & Mediun \\
\hline High & Mediun & Low & Low \\
\hline High & Mediun & Low & High \\
\hline Low & Low & High & Low \\
\hline High & Medium & Low & High \\
\hline High & Medium & Low & Medium \\
\hline High & Low & Low & Mediun \\
\hline High & Mediun & Low & Mediun \\
\hline High & Low & Low & Mediun \\
\hline High & Low & Low & Medium \\
\hline High & Low & Low & Mediun \\
\hline Low & High & High & Mediu \\
\hline High & Low & Low & Mediun \\
\hline Mediun & Low & High & Mediun \\
\hline
\end{tabular}

\footnotetext{
(a) Solubility: High > g/L; $\mathrm{g} / \mathrm{L} \geq$ Medium $\geq \mathrm{mg} / \mathrm{L}$; Low $\langle\mathrm{mg} / \mathrm{L}$

(b) Volatility: High $>5 \times 10^{-2} \mathrm{~atm}^{\bullet} \mathrm{m}^{3} / \mathrm{mol} ; 5 \times 10^{-2} \geq$ Medium $\geq 1 \times 10^{-4} \mathrm{~atm}^{\circ} \mathrm{m}^{3} / \mathrm{mol}$; Low $<1 \times 10^{-4} \mathrm{~atm} \bullet^{3} / \mathrm{mol}$.

(c) Sorption: High $R_{d}>50 \mathrm{~mL} / \mathrm{g} ; 50 \mathrm{~mL} / \mathrm{g} \geq$ Medium $\geq 2 \mathrm{~mL} / \mathrm{g} ;$ Low $<2 \mathrm{~mL} / \mathrm{g}$

(d) -- = No basis to make an estimate.
} 



\subsection{FUTURE WORK}

Regulations dealing with waste disposal require risk, health, and performance assessment analyses before licensing or remedial cleanup of disposal sites. These assessment analyses must predict the transport of radionuclides/contaminants from the waste source to a receptor via pathways that are considered credible. The groundwater pathway is generally most significant when long-term effects are considered. Geochemical reactions between contaminants and the groundwater pathway and hydrologic characteristics largely control release and transport to the accessible environment or receptor. Consequently, data that quantify these geochemical reactions are required to adequately complete a risk/health/performance assessment.

Sites at Hanford that contain contaminated soil include injection wells, covered French drains, cribs (covered drain fields), trenches, and ponds. Currently, the contaminants within inactive disposal sites with contaminated soil exist as precipitated radionuclides and/or hazardous constituents that are bound in the soil column after discharged waste solutions have drained. The types of liquid wastes that were or are currently being disposed of at the Hanford Site range from very-low-ionic-strength cooling waters and condensates to high-salt process wastes, with $\mathrm{pH}$ values ranging from less than 1 to more than 12. As mentioned in Section 2.0, the pH of the 33 active waste streams ranges between 5 and 10.5. Many of the alkaline waste streams disposed of in the past contained suspended particles of insoluble compounds. Some waste streams contained significant concentrations of organic solvents and complexing agents. Geochemical conditions (ambient water chemistry, soil exchange capacity, and soil buffering capacities) in the soil may vary widely as a function of discharge fluid chemistry and spatial proximity to the source of discharge.

Conceptual leaching models for contaminated soils have not been well established. It appears that two conceptual models, desorption and solubility, will be needed, depending on the contaminant of interest. To characterize and predict release and transport of radionuclides and/or

\section{1}


hazardous constituents, solubility and sorption values specific to these various environments are needed. The quantity and quality of available experimental and theoretical data vary with the environments. The best, most complete database is the one that corresponds to the moderately alkaline, lowionic-strength, organic-free groundwater contacting sandy soil, an environment that is in fact typical of much of the Hanford Site's vadose zone and unconfined aquifer. Although the amount of actual data in the database (radionuclide sorption and solubility measurements using Hanford soil and groundwater) is moderate, sufficient experimental work has been reported in the literature that a plausible range of sorption and solubility values can be estimated for many radionuclides and inorganic contaminants. The database needed to quantify, with technical defensibility, specific solubility or sorption values for radionuclides and/or hazardous constituents is generally inadequate, and current transport modeling predictions should be considered as initial, rough estimates. The problem of inadequacy is compounded by the lack of specific data that quantify concentrations of radionuclides, hazardous constituents, and organic and inorganic complexants at existing contaminated soil sites.

To generate a useful database despite the lack of site-specific information, a list of potential conditions and important chemical constituents has been identified from records and past site-specific investigations (Serne and Wood 1990). It is recommended that a series of sorption and empirical solubility tests be run on the basis of the information available on inactive waste streams from Serne and Wood (1990) and the information on active waste streams from Westinghouse Hanford (1989). Hanford Site soils should be used in these tests to provide ranges of sorption and solubility values for use in transport modeling. Because of the current lack of information, emphasis must be placed on organic constituent interactions with Hanford sediments. Actual data that describe the effects of partial saturation on radionuclide or contaminant transport in Hanford soils are very sparse and more must be obtained. The primary tests to be completed include 1) batch sorption/desorption tests to develop distribution coefficients or empirical solubility values and to identify areas requiring further study, and 2) flow-through column tests to quantify retardation factors under the 
combined influences of hydrologic flow and chemical/reactivity so that sorption/desorption hysteresis and effects of unsaturated moisture contents, if any, can be determined. The parameters other than the chemical components that should be varied in the test matrix include soil types, moisture content, and flow characteristics (e.g., advection flow rates and diffusion fluxes as a function of moisture content).

The sorption/desorption of an organic group, such as the alkanes or phthalates, should be experimentally examined as a function of several mixed waste compositions. Emphasis should be placed on sorption/desorption systems involving methylene chloride, chloroform, bis(2-ethythexyl) phthalate, acetone, methyl ethyl ketone, and tetrachloroethylene, which have been recently identified as leaking through the soil column into groundwater monitoring wells adjacent to wastewater disposal sites (Appendix B). Accompanying radionuclides that are also commonly detected as leaking through the soil column into the groundwater with these organics include ${ }^{3} \mathrm{H},{ }^{60} \mathrm{Co}$, ${ }^{90} \mathrm{Sr},{ }^{99} \mathrm{Tc},{ }^{106} \mathrm{Ru},{ }^{129} \mathrm{I}$, and ${ }^{137} \mathrm{Cs}$. In many Hanford waste streams, the Co, I, $\mathrm{Ru}$, and Tc are usually anionic or partially anionic and can therefore be expected to sorb poorly on the soil column (i.e., to be mobile). Tritium is present as water and would also be expected to be mobile. However, $\mathrm{Cs}$ and $\mathrm{Sr}$ are normally present as cations and hence could be expected to sorb readily on the soil column. The fact that ${ }^{90} \mathrm{Sr}$ and ${ }^{137} \mathrm{Cs}$ are commonly found in groundwaters adjacent to wastewater disposal sites suggests that there may be unknown reactions between these radionuclides and the organics in mixed wastes, such as complexing, that have resulted in the leakage of radionuclides that are ordinarily adsorbed strongly. It is suggested that ${ }^{85} \mathrm{Sr}$ and ${ }^{134} \mathrm{Cs}$ or ${ }^{137} \mathrm{Cs}$, as gamma-emitting isotopes, be added as tracers during selected experiments with the mixed-waste column studies proposed above. The two radionuclides can be counted together to reduce the total number of experiments required to understand the mixed-waste system.

Furthermore, some biodegradation studies (in batch reactors) of the organics and of others in Table 5 that have low adsorption and high water solubility potential should be performed under Hanford-specific conditions. Initial studies should be performed on Hanford sediments and active waste 
streams that have been acclimated to optimize growth of native microbes. Particular attention should be paid to the effects of moisture content on the rates of microbial degradation.

These initial batch equilibration and column tests would be used to furnish data for models to describe the process of contaminant sorption/ desorption/migration through actual Hanford sediments. This data collection scheme emphasizes laboratory testing based on empiricism; in the tests the expected environment is simulated, and geochemical and microbial reactions are measured through standard adsorption, solubility, and degradation tests. The data collection effort should rely on feedback from performance analyses (Serne and Wood 1990, pp. 1.4-1.6) to ascertain when adequate data have been collected. The data collection scheme proposed is estimated to take 3 personyears effort per year for a total duration of 4 years.

In the constant $R_{d}$ model, the distribution of the contaminant of interest between the solid adsorbent and solution is assumed to be a constant value. There is no explicit accommodation of dependence on characteristics of the sediment, groundwater, or contaminant concentration. Possible retardation mechanisms include 1) chemical precipitation of bulk solid phases, 2) chemical substitution of one element for another in a solid phase, 3) exchange of a stable isotope of an element with a radioactive isotope in solution, 4) physical filtration of colloids, 5) cation and anion exchange, 6) chemisorption, and 7) physical adsorption. All these mechanisms are melded into the empirical distribution coefficient. The limitations associated with this approach are well known to investigators, but the paucity of Hanford Site-specific geochemical data precludes a more rigorous conceptual retardation model at this time. The constant $R_{d}$ model is mathematically very simple and can be readily incorporated into transport models and codes.

A second practical conceptual model for adsorption is the parametric $R_{d}$ model. Numerous statistical strategies have been used to develop empirical relationships that describe $R_{d}$ as a function of other variables, such as the amount and types of minerals present in the sediment, amounts and types of dissolved species in the groundwater, $\mathrm{pH}$, and Eh. Parametric $\mathrm{R}_{\mathrm{d}}$ relationships delineate apparent effects of key variables but do not conclusively identify 
controlling processes. These statistical approaches have been demonstrated to yield accurate predictions for conditions within the range of conditions studied. When the parametric $R_{d}$ retardation model is used, the performance assessment code must keep track of the current values of all of the independent variables that determine the value of $R_{d}$. Because of the added complexity of solving the transport equation, explicit use of the parametric $R_{d}$ model has been rare. On the other hand, the parametric $R_{d}$ approach can be used to objectively develop a suite of time- or space-dependent constant $R_{d}$ values to be used in a given performance assessment analysis. This modified approach is recommended for near-future Hanford performance assessment activities. To pursue the parametric $R_{d}$ approach, the same types of batch and column tests are required but more thorough characterization of the sediments and solutions is necessary. The projected cost for the more detailed characterization would be increased by a factor of 1.5 to 2 .

As the data are collected, it would be beneficial to explore the efficacy of more detailed mechanistic studies to elucidate the controlling solubility, adsorption, microbiological, and physical (e.g., volatilization) reactions that determine the fate of the contaminants. Knowledge of the controlling reactions/processes is required to lend credibility to the predictions made using performance, risk, or health assessment computer codes. The costs of performing such mechanistic tests cannot be determined at this time. Again, feedback from performance assessment activities (e.g., sensitivity studies, identification of key contaminants from consequence or health effects modeling) should be used to focus and prioritize the mechanistic tests to be performed. 


\subsection{REFERENCES}

Ames, L. L., and D. Rai. 1978. Radionuclide Interactions with Soil and Rock Media. EPA 520/6-78-007, Vol. 1, U.S. Environmental Protection Agency, Las Vegas, Nevada.

ASTM. 1984. "D4319-83, Distribution Ratios by the Short-Term Batch Method," In Annual Book of ASTM Standards, Vol. 04.08, pp. 766-773. American Society for Testing and Materials, Philadelphia, Pennsylvania.

Barney, G. S. 1978. Variables Affecting Sorption and Transport of Radionuclides in Hanford Subsoils. RHO-SA-87, Rockwell Hanford Operations, Richland, Washington.

Benson, D. W. 1960. Review of Soil Chemistry Research at Hanford. HW-67201, General Electric Company, Richland, Washington.

Benson, D. W. 1961. Mineral Adsorption of Radionuclides in Reactor Effluent. HW-69225, General Electric Company, Richland, Washington.

Benson, D. W., J. L. Nelson, and G. J. Alkire. 1963. Chemical and Physical Properties of 100 Area Soils. HW-76181, General Electric Company, Richland, Washington.

Blake, C. A., Jr., W. Davis, Jr., and J. M. Schmitt. 1963. "Properties of Degraded TBP-Amsco Solutions and Alternative Extractant - Diluent Systems." Nucl. Sci. and Eng. 17:626-637.

Briggs, G. G. 1973. "A Simple Relationship Between Soil Sorption of Organic Chemicals and Their Octanol/Water Partition Coefficients." Proc. 7th Bri. Insecticide Fungicide Conf. 11:475-478.

Brown, D. J. 1967. Migration Characteristics of Radionuclides Through Sediments Underlying the Hanford Reservation. ISO-SA-32, Isochem, Richland, Washington.

Brown, D. J., and W. A. Haney. 1964. Chemical Effluents Technology Waste Disposal Investigations July-December, 1963 - The Movement of Contaminated Ground Water From the 200 Areas to the Columbia River. HW-80909, General Electric Company, Richland, Washington.

Brown, D. S., and E.W. Flagg. 1981. "Empirical Prediction of Organic Pollutant Sorption in Natural Sediments." J. Environ. Qual. 10(3):382-386.

Buelt, J. L., W. Conbere, M. D. Freshley, R. J. Hicks, W. L. Kuhn, D. A. Lamar, R. J. Serne, and J. L. Smoot. 1988. The Predicted Impacts to the Groundwater and Columbia River from Ammoniated Water Discharges to the 216-A36B Crib. PNL-6463, Pacific Northwest Laboratory, Richland, Washington.

Burr, J. G. 1958. "The Radiolysis of Tributyl Phosphate." Radiation Res. $8: 214-221$. 
Chiou, C. T., V. H. Freed, D. W. Schmedding, and R. L. Kohnert. 1977.

"Partition Coefficient and Bioaccumulation of Selected Organic Chemicals." Environ. Sci. Technol. 11:475-478.

Chiou, C. T., L. J. Peters, and V. H. Freed. 1979. "A Physical Concept of Soil-Water Equilibria for Nonionic Organic Compounds." Science 206:831-832.

Coughtrey, P. J., D. Jackson, and M. C. Thorne. 1983-1984. Radionuclide Distribution and Transport in Terrestrial and Aquatic Ecosystems, Vol.\#1-6, A. A. Balkema, Brookfield, Vermont.

Delegard, C. H., and G. S. Barney. 1983. Effects of Hanford High-Level Waste Components on Sorption of Cobalt, Strontium, Neptunium, Plutonium, and Americium of Hanford Sediments. RHO-RE-ST-1 P, Rockwe11 Hanford Operations, Richland, Washington.

Delegard, C. H., and S. A. Gallagher. 1983. Effects of Hanford High-Level Waste Components on Solubility of Cobalt, Strontium, Neptunium, Plutonium, and Americium on Hanford Sediments. RHO-RE-ST-3 P, Rockwell Hanford Operations, Richland, Washington.

Delegard, C. H., G. S. Barney, and S. A. Gallagher. 1984. "Effects of Hanford High-Level Waste Components on the Solubility and Sorption of Cobalt, Strontium, Neptunium, Plutonium, and Americium." ACS Symp. Ser. 246:95-112.

Dennis, B. P., and D. L. West. 1961. Evaluation of Hydrocarbon Diluents for the PUREX Process. DP-671, Savannah River Laboratory, Aiken, South Carolina.

Dowty, B., D. Carlisle, and J. L. Laseter. 1975. "Halogenated Hydrocarbons in New Orleans Drinking Water and Blood Plasma." Science 187:75-77.

Drever, J. I. 1982. The Geochemistry of Natural Waters. Prentice-Hall, Englewood Cliffs, New Jersey.

Ecology. 1987. "Dangerous Waste Regulations." Washington Administrative Code. WAC 173-303, Sections 090, 101, 102, and 103, 01ympia, Washington.

Ecology. 1988. "State of Washington Waste Discharges Permit Program." Washington Administrative Code WAC 173-216, Olympia, Washington.

Emery, R. M., and T. R. Garland. 1974. Ecological Behavior of Plutonium and Americium in a Fresh Water Ecosystem. Phase II. Implications of Differences in Transuranic Isotopic Ratios. BNWL-1879, Pacific Northwest Laboratory, Richland, Washington.

Emery, R. M., D. C. Klopfer, and W. C. Weimer. 1974. Ecological Behavior of Plutonium and Americium in a Fresh Water Ecosystem. Phase I. Limnological Characterization of Isotopic Distribution. BNWL-1867, Pacific Northwest Laboratory, Richland, Washington. 
Evans, J. C., P. J. Mitche11, and D. I. Dennison. 1988a. Hanford Site GroundWater Monitoring for April Through June 1987. PNL-6315-1, Pacific Northwest Laboratory, Richland, Washington.

Evans, J. C., D. I. Dennison, R. W. Bryce, P. J. Mitche11, D. R. Sherwood, K. M. Krupka, N. W. Hinman, E. A. Jacobson, and M. D. Freshley. 1988b. Hanford Site Ground-Water Monitoring for July through December 1987. PNL-6315-2, Pacific Northwest Laboratory, Richland, Washington.

Evans, J. C., R. W. Bryce, D. R. Sherwood, M. L. Kemner, and D. R. Newcomer. 1989. Hanford Site Ground-Water Monitoring for July Through December 1988. PNL-7120, Pacific Northwest Laboratory, Richland, Washington.

Farmer, W. J. 1976. "Leaching, Diffusion and Sorption of Benchmark Pesticides." In A Literature Survey of Benchmark Pesticides, pp. 185-244. George Washington Medical Center, Washington, D.C.

Felmy, A. R., D. C. Girvin, and E. A. Jenne. 1984. MINTEQ: A Computer Program for Calculating Aqueous Geochemical Equilibria. EPA-600/3-84-032, U.S. Environmental Protection Agency, Athens, Georgia.

Gaumann, T., S. Rappoport, and A. Ruf. 1972. "The Effect of Temperature in the Radiolys is of Paraffins." J. Phys. Chem. 76(25):3851-3855.

Gee, G. W., and J. W. Bauder. 1986. "Particle-Size Analysis." In Methods of Soil Analysis, Part 1, ed. A. Klute, pp. 383-411. American Society of Agronomy, Madison, Wisconsin.

Hajek, B. F. 1966. Plutonium and Americium Mobility in Soils. BNWL-CC-925, Pacific Northwest Laboratory, Richland, Washington.

Hajek, B. F., and L. L. Ames, Jr. 1968. Trace Strontium and Cesium Equilibrium Distribution Coefficients: Batch and Column Determinations. BNWL-SA-843, Pacific Northwest Laboratory, Richland, Washington.

Hajek, B. F., and K. C. Knoll. 1966. Disposal Characteristics of Plutonium and Americium in a High Salt Acid Waste. BNWL-CC-649, Pacific Northwest Laboratory, Richland, Washington.

Hamaker, J. W., and J. M. Thompson. 1972. "Adsorption." In Organic Chemicals in the Soil Environment, eds. C. A. I. Goring and J. W. Hamaker, pp. 49-143. Marcel Dekker, New York.

Haney, W. A. 1957. Disposal of High Cobalt-60 Scavenged Wastes. HW-48862, General Electric Company, Richland, Washington.

Haney, W. A. 1964. "Consequences of Activity Release." Nuclear Safety $5: 399-403$.

Haney, W. A. 1967. Final Report on the Effects of Ben Franklin Dam on Hanford. BNWL-412, Pacific Northwest Laboratory, Richland, Washington. 
Hansch, C., J. E. Quinlan, and G. L. Lawrence. 1968. "The Linear Free-Energy Relationship Between Partition Coefficients and the Aqueous Solubility of Organic Liquids." J. Org. Chem. 33:347-350.

Hawkins, D. B., and H. L. Short. 1965. Equations for the Sorption of Cesium and Strontium on Soil and Clinoptilolite. IDO-12046, U.S. Department of Energy, Idaho Falls, Idaho.

Howard, P. H., A. E. Hueber, B. C. Muelesky, J. S. Crisman, W. Meylan, E. Crosbie, B. A. Gray, G. W. Sage, and K. P. Howard. 1986. "BIOLOG, BIODEG, and FATE/EXPOS: New Files on Microbial Degradation and Toxicity as Well as Environmental Fate/Exposure of Chemicals." Environ. Toxicol. Chem. 5:977-988.

Huffman, E. W. D. 1977. "Performance of a New Automatic Carbon Dioxide Coulometer." Microchem. J. 22:567-573.

Huggard, A. J., and B. F. Warner. 1963. "Investigations to Determine the Extent of Degradation of TBP/Odorless Kerosene Solvent in the New Separation Plant, Windscale." Nucl. Sci. Eng. 17:638-650.

Jungfleisch, F. M. 1988. Preliminary Evaluation of Hanford Liquid Discharges to Ground. WHC-EP-0052, Westinghouse Hanford Company, Richland, Washington.

Karickhoff, S. W. 1981. "Semi-Empirical Estimation of Sorption of Hydrophobic Pollutants on Natural Sediments and Soils." Chemosphere 10:833-846.

Karickhoff, S. W. 1984. "Organic Pollutant Sorption in Aquatic Systems." J. Hydraulic Eng. ASCE 110:707-735.

Karickhoff, S. W., D. S. Brown, and T. A. Scott. 1979. "Sorption of Hydrophobic Pollutants on Natural Sediments." Water Research 13:241-248.

Knol1, K. C. 1969. Reactions of Organic Wastes in Soils. BNWL-860, Pacific Northwest Laboratory, Richland, Washington.

Lambert, S. M., P. E. Porter, and H. Schieferstein. 1965. "Movement and Sorption of Chemicals Applied to the Soil." Weeds 13:185-190.

Lane, E. S. 1960. Some Aspects of the Chemistry of Kerosene and Related Inert Diluents Relevant to Their Use in Extraction Plants. AERE-R-3501, Atomic Energy Research Establishment, Harwe11, England.

Lane, E. S. 1963. "Performance and Degradation of Diluents for TBP and the Cleanup of Degraded Solvents." Nucl. Sci. Eng. 17:620-625.

Larson, R. A., and A. L. Rockwe11. 1979. "Chloroform and Chlorophenol Production by Decarboxylation of Natural Acids During Aqueous Chlorination." Environ. Sci. Technol. 13:325-329.

Lindsay, W. L. 1979. Chemical Equilibria in Soils. John Wiley and Sons, New York. 
Lyman, W. J., W. F. Reehl, and D. H. Rosenblatt. 1982. Handbook of Chemical Property Estimation Methods: Environmental Behavior of Organic Compounds. McGraw-Hi11, New York.

McHenry, J. R. 1954. Adsorption and Retention of Cesium by Soils of the Hanford Project. HW-31011, General Electric Company, Richland, Washington.

McHenry, J. R. 1957. Properties of Soils of the Hanford Project. HW-53218, General Electric Company, Richland, Washington.

McHenry, J. R. 1958. "Ion Exchange Properties of Strontium in a Calcareous Soil." Soil Sci. Soc. Am. Proc. 22:514-518.

Means, J. C., J. J. Hassett, S. G. Wood, W. L. Banwart, S. Ali, and A. Khan. 1980a. "Sorption Properties of Polynuclear Aromatic Hydrocarbons and Sediments: Heterocyclic and Substituted Compounds." In Polynuclear Aromatic Hydrocarbons: Chemistry and Biological Effects, eds. A. Bjorseth and A. J. Dennis, pp. 395-404. Battelle Press, Columbus, Ohio.

Means, J. C., S. G. Wood, J. J. Hassett, and W. L. Banwart. 1980. "Sorption of Polynuclear Aromatic Hydrocarbons by Sediments and Soils." Environ. Sci. Technol. 14:1524-1528.

Means, J. C., S. G. Wood, J. J. Hassett, and W. L. Banwart. 1982. "Sorption of Amino- and Carboxy-Substituted Polynuclear Aromatic Hydrocarbons by Sediments and Soils." Environ. Sci. Technol. 16:93-98.

Millikin, E. J. 1989. Annual Status Report of the Plan and Schedule to Discontinue Disposal of Contaminated Liquids into the Soil Column at the Hanford Site, Fiscal Year 1989. WHC-EP-0196-2, Westinghouse Hanford Company, Richland, Washington.

Muller, A. B., D. Langmuir, and L. E. Duda. 1983. "The Formulation of an Integrated Physicochemical-Hydrologic Model for Predicting Waste Nuclide Retardation in Geologic Media." In Scientific Bas is for Nuclear Waste Management VI, Proceedings of Materials Research Society Symposia, ed. D. G. Brookings, pp. 547-564. North Holland, New York.

Nordstrom, D. K., and J. L. Munoz. 1985. Geochemical Thermodynamics. Benjamin/Cummings Publishing, Menlo Park, California.

Norwood, D. L., J. D. Johnson, R. F. Christman, J. R. Hass, and M. J. Bobenvieth. 1980. "Reactions of Chlorine with Selected Aromatic Models of Aquatic Humic Material." Environ. Sci. Technol. 14:187-190.

Nowak, Z. 1971. "The Radiolysis of Diluent - TBP - $\mathrm{HNO}_{3}$ Systems." Nukleonika $16(3-4): 39-47$, Engl. trans.

Peterson, S. R., C. J. Hostetler, W. J. Deutsch, and C. E. Cowan. 1987. MINTEQ User's Manual. NUREG/CR-4808, PNL-6106, prepared by Pacific Northwest Laboratory for the U.S. Nuclear Regulatory Commission, Washington, D. C. 
Prout, W. E. 1959. Adsorption of Fission Products by Savannah River Plant Soil. DP-394, Savannah River National Laboratory, Aiken, South Carolina.

Raymond, J. R. 1964. Investigation of the Disposition and Migration of Gross Gamma Emitters Beneath Liquid Waste Disposal Sites. HW-81746, General Electric Company, Richland, Washington.

Raymond, J. R. 1965. Cesium and Strontium Distribution Beneath Liquid Waste Disposal Sites. BNWL-235, Pacific Northwest Laboratory, Richland, Washington.

Rai, D., and R. J. Serne. 1978. Solid Phases and Solution Species of Different Elements in Geologic Environments. PNL-2651, Pacific Northwest Laboratory, Richland, Washington.

Rhodes, D. W. 1956. Adsorption by Soil of Strontium from 216-S Crib Waste. HW-42699, General Electric Company, Richland, Washington.

Rhodes, D. W. 1957a. "The Effect of pH on the Uptake of Radioactive Isotopes from Solution by a Soil." Soil Sci. Soc. Am. Proc. 21:389-392.

Rhodes, D. W. 1957b. "The Adsorption of Plutonium by Soil." Soil Sci. $84: 465-471$.

Rhodes, D. W., and J. L. Nelson. 1957. Disposal of Radioactive Liquid Wastes from the Uranium Recovery Plant. HW-54721, General Electric Company, Richland, Washington.

Rook, J. J. 1977. "Chlorination Reactions of Fulvic Acids in Natural Waters." Environ. Sci. Technol. 11:478-482.

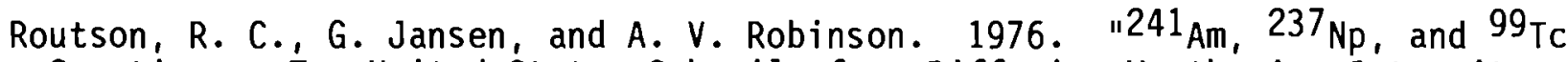
Sorption on Two United States Subsoils from Differing Weathering Intensity Areas." Health Phys. 33:311-317.

Routson, R. C., G. S. Barney, R. M. Smith, C. H. Delegard, and L. Jensen. 1981. Fission Product Sorption Parameters for Hanford 200 Area Sediment Types. RH0-ST-35, Rockwell Hanford Operations, Richland, Washington.

Schwarzenbach, R. P., and J. Westal1. 1981. "Transport of Nonpolar Organic Compounds from Surface-Water to Groundwater: Laboratory Sorption Studies." Environ. Sci. Technol. 15:1360-1367.

Serne, R. J., and J. F. Relyea. 1983. "The Status of Radionuclide SorptionDesorption Studies Performed by the WRIT Program." In Technology of HighLevel Nuclear Waste Disposal, Vol. 1, pp. 203-254. DOE/TIC-621, Technical Information Center, U.S. Department of Energy, Oak Ridge, Tennessee.

Serne, R. J., and M. I. Wood. 1990. Hanford Waste-Form Release and Sediment Interaction - A Status Report with Rationale and Recommendations for Additional Studies. PNL-7297, Pacific Northwest Laboratory, Richland, Washington. 
Sheppard, J. C., J. A. Kittrick, and T. L. Hardt. 1976. Determination of Distribution Ratios and Diffusion Coefficients of Neptunium, Americium, and Curium in Soil-Aquatic Environments. RL0-2221-T-12-2 (WSU 76/13-33), Washington State University, Pullman, Washington.

Sims, R. C., J. L. Sims, W. J. Grenney, and S. G. Hansen. 1988. Soil Transport and Fate Database. Robert S. Kerr Environmental Research Laboratory, Ada, 0klahoma.

Stordeur, R. T., and D. L. Flyckt. 1988. Annual Status Report of the Plan and Schedule to Discontinue Disposal of Contaminated Liquids into the Soil Column at the Hanford Site. WHC-EP-0196-1, Westingouse Hanford Company, Richland, Washington.

Stumm, W., and J. J. Morgan. 1981. Aquatic Chemistry. John Wiley and Sons, New York.

USGS. 1987. Subsurface Transport of Radionuclides in Shallow Deposits of the Hanford Nuclear Reservation, Washington--Review of Selected Previous Work and Suggestions for Further Study. Open-File Report 87-222, U.S. Geological Survey, Denver, Colorado.

Westinghouse Hanford. 1989. Waste Stream Characterization Report. WHC-EP-0287, 4 vols., Westinghouse Hanford Company, Richland, Washington.

Wilding, M. W., and D. W. Rhodes. 1963. Removal of Radioisotopes from Solution by Earth Materials from Eastern Idaho. ID0-14624, U.S. Department of Energy, Idaho Falls, Idaho.

Wildung, R. E., R. C. Routson, R. J. Serne, and T. R. Garland. 1975. Pertechnetate, Iodide, and Methyl Iodide Retention by Surface Soils. BNWL-1950, Pt. 2, pp. 37-40. Pacific Northwest Laboratory, Richland, Washington.

Witkowski, P. J., J. A. Smith, T. V. Fusillo, and C. T. Chiou. 1987. A Review of Surface-Water Sediment Fractions and Their Interactions with Persistent Manmade Organic Compounds. USGS Circular 993, U.S. Geological Survey, Denver, Colorado. 


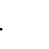




\begin{abstract}
APPENDIX A
ENVIRONMENTAL FATE OF ORGANIC ANALYTES
\end{abstract}

REPORTED IN THE 33 WASTE STREAMS 
ENVIRONMENTAL FATE OF ORGANIC ANALYTES

REPORTED IN THE 33 WASTE STREAMS

Classes of organic analytes found in the 33 waste streams are organized by functional groups. Classes of organics in the 33 waste streams (see Table 5 in main text) include alkanes, alcohols, organic acids, amines, polyhydric alcohols or glycols, ethers, phthalic acid- and carboxylic acid-esters, nitro compounds, caustic aromatics, ketones, aldehydes, halides and polynuclear aromatic hydrocarbons. The above structures are illustrated in Table A.1. In addition to the structural group involved, this appendix also lists other physical and chemical properties of the identified analytes, organized by class. Properties such as the Freundlich $1 / \mathrm{N}$ and retardation factor where available, octanol-water partition coefficients $\left(K_{0} / w\right)$, and soil organic carbon adsorption coefficients $\left(K_{O C}\right)$, water solubility, and Henry's law constant used to predict volatility are also provided (sources are identified in the reference list at the back of the appendix). Explanations of these terms are given in Section 4.6 of this report. The Chemical Abstracts Service Registry Number (CAS No.) is given under each analyte when available. Hazardous categories for many of the organic analytes given in this appendix are given by Jungfleisch (1988). 
TABLE A.1. Classification of Organic Analytes According to Functional Groups

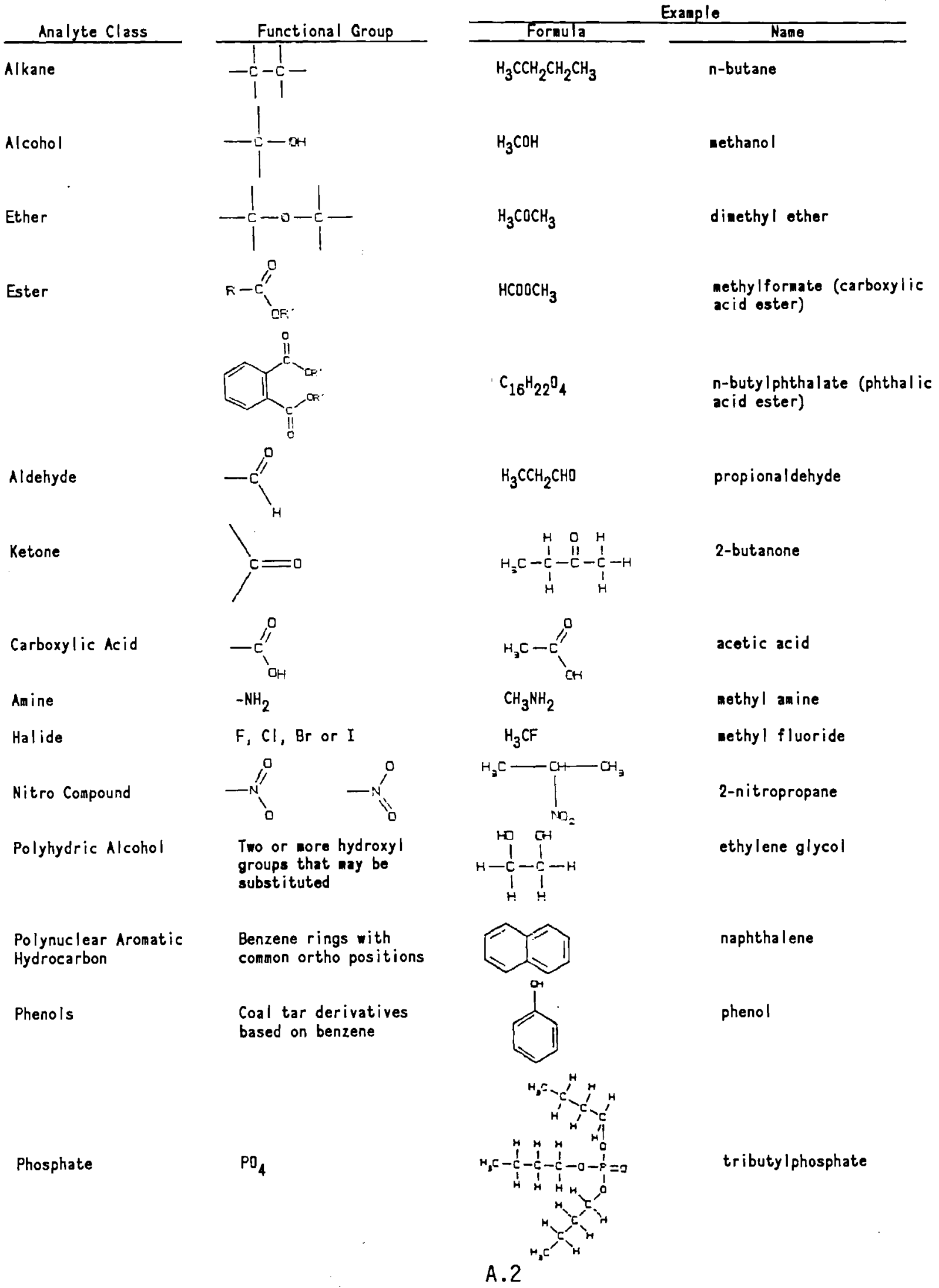




\section{A.2 ALKANES}

$-c-1$

A. 3 
Decane

$\mathrm{H}_{3} \mathrm{C}\left(\mathrm{CH}_{2}\right)_{8} \mathrm{CH}_{3}$

CAS No. $124-18-5$

Synonyms: $n$-decane

Melting Point: $-30^{\circ} \mathrm{C}$ (Buckingham 1982, V2:1459)

Boiling Point: $174^{\circ} \mathrm{C}$ (Buckingham 1982, V2:1459)

Density: $0.73 \mathrm{~g} / \mathrm{cm}^{3}$ liquid at environmental temperatures (Buckingham 1982, V2:1459)

Vapor Pressure: $0.175 \mathrm{KPa}\left(1.75 \times 10^{-3} \mathrm{~atm}\right)$ (MacKay and Shiu 1981)

Solubility: $0.0254 \mathrm{mg} / \mathrm{L}$ (MacKay et al. 1981; MacKay and Shiu 1981)

$0.052 \mathrm{mg} / \mathrm{L}$ (Mackay and Shiu 1981; Coates et al. 1985)

Henry's Law Constant: $0.3 \mathrm{~atm} \cdot \mathrm{m}^{3} / \mathrm{mol}$ (Wakeham et al. 1986)

5 to $1.08 \times 10^{+} \mathrm{atm}^{\circ} \mathrm{m}^{3} / \mathrm{mol}$ (MącKay and Shiu 1981) recommended value $7 \neq 3 \mathrm{~atm} \bullet \mathrm{m}^{3} / \mathrm{mol}$

$\mathrm{K}_{\mathrm{O} / \mathrm{w}}: \begin{aligned} & 1.02 \times 10^{5} \quad \text { (Coates et al. 1985) } \\ & 1.66 \times 10^{6} \text { (Hawker and Conne } 11 \text { 1989) }\end{aligned}$ 
Dodecane

$\mathrm{H}_{3} \mathrm{C}\left(\mathrm{CH}_{2}\right){ }_{10} \mathrm{CH}_{3}$

CAS No. $112-40-3$

Freezing Point: $-12^{\circ} \mathrm{C}$ (Buckingham 1982, V2:2 389-90)

$-9.6^{\circ} \mathrm{C}$ (Mackay and Shiu 1981)

Boiling Point: $214.5^{\circ} \mathrm{C}$ (Buckingham 1982, V2:2 389-90)

$216.3^{\circ} \mathrm{C}$ (Mackay and Shiu 1981)

Vapor Pressure: $1.57 \times 10^{-2} \mathrm{kPa}\left(1.57 \times 10^{-4} \mathrm{~atm}\right)$ (Mackay and Shiu 1981) at $25^{\circ} \mathrm{C}$

Solubility: $0.0034 \mathrm{mg} / \mathrm{L}$ (MacKay and Shiu 1981);

$0.0037 \mathrm{mg} / \mathrm{L}$ (MacKay and Shiu 1981; Sutton and Calder 1974)

$0.0084 \mathrm{mg} / \mathrm{L}$ (Mackay and Shiu 1981; Coates et al. 1985)

Henry's Law Constant: 3.17 to $7.86 \mathrm{~atm} \bullet \mathrm{m}^{3} / \mathrm{mol}$ (Mackay and Shiu 1981) recommended value $7.5 \pm 2.5 \mathrm{~atm} \bullet \mathrm{m}^{3} / \mathrm{mol}$

$K_{o / w}: 1.26 \times 10^{6}$ (Coates et al. 1985) $10^{6}$ (Wakeham et al. 1983)

Degradation Rate: $t 1 / 2 \sim 5$ days in soil slurry when dodecane conc $3.3 \mathrm{mg} / \mathrm{L}$ (Haines and Alexander 1974)

t1/2 $\sim 10-15$ days in sediment/seawater (Nazata and Kondo 1977) 


\section{Tridecane}

$\mathrm{H}_{3} \mathrm{C}\left(\mathrm{CH}_{2}\right)_{11} \mathrm{CH}_{3}$

CAS No. 629-50-5

Freezing Point: $-5.5^{\circ} \mathrm{C}$ (Buckingham 1982, V5:5463)

Boiling Point: $234^{\circ} \mathrm{C}$ (Buckingham 1982, V5:5463)

Density: $0.7564 \mathrm{~g} / \mathrm{cm}^{3}$; liquid at environmental temperatures (Buckingham 1982, V5:5162)

Solubility: $0.00104 \mathrm{mg} / \mathrm{L}$ (Coates et al. 1985)

$K_{0} / w: 4.47 \times 10^{6} \quad$ (Coates et al. 1985) 
Tetradecane

$\mathrm{H}_{3} \mathrm{C}\left(\mathrm{CH}_{2}\right)_{12} \mathrm{CH}_{3}$

CAS No. 629-59-4

Melting Point: $5.9^{\circ} \mathrm{C}$ (Buckingham 1982, V5:5162; Mackay and Shiu 1981)

Boiling Point: $253.7^{\circ} \mathrm{C}$ (Buckingham 1982, V5:5162; Mackay and Shiu 1981)

Density: $0.7628 \mathrm{~g} / \mathrm{cm}^{3}$ liquid at environmental temperatures (Buckingham 1982, V5:5162)

Vapor Pressure: 1.24 to $1.27 \times 10^{-3} \mathrm{kPa}$; liquid at environmental temperatures (Buckingham 1982, V5:5162)

Solubility: $0.0022 \mathrm{mg} / \mathrm{L}$ (MacKay and Shiu 1981; Sutton and Calder 1974)

$0.0077 \mathrm{mg} / \mathrm{L}$ (MacKay and Shiu 1981; Sutton and Calder 1974)

$0.00028 \mathrm{mg} / \mathrm{L}$ (Coates et al. 1985)

$0.00033 \mathrm{mg} / \mathrm{L}$ (Coates et a1. 1985)

Henry's Law Constant: $3.47 \times 10^{-1}$ to $1.1 \times 10^{-0} \mathrm{~atm} \bullet \mathrm{m}^{3} / \mathrm{mol}$ (Mackay and Shiu 1981)

$K_{o} / w^{\prime}: 1.58 \times 10^{7}$ (Mackay and Shiu 1981) 


\section{Pentadecane}

$\mathrm{H}_{3} \mathrm{C}\left(\mathrm{CH}_{2}\right){ }_{13} \mathrm{CH}_{3}$

CAS No. 629-62-9

Melting Point: $10^{\circ} \mathrm{C}$ (Buckingham 1982, V4:4513)

Boiling Point: $270^{\circ} \mathrm{C}$ (Buckingham 1982, V4:4513)

Density: $0.7685 \mathrm{~g} / \mathrm{cm}^{3}$; could be liquid or solid at environmental temperatures Solubility: $0.000076 \mathrm{mg} / \mathrm{L}$ (Coates et al. 1985)

$\mathrm{K}_{\mathrm{O} / \mathrm{w}}: 5.25 \times 10^{7}$ (Coates et al. 1985) 
Hexadecane

$\mathrm{H}_{3} \mathrm{C}\left(\mathrm{CH}_{2}\right){ }_{14} \mathrm{CH}_{3}$

CAS No: 544-76-3

Synonym: n-hexadecane cetane

Melting Point: $18.2^{\circ} \mathrm{C}$ (Buckingham 1982, V3:2895; Mackay and Shiu 1981)

Boiling Point: $287^{\circ} \mathrm{C}$ (Buckingham 1982, V3:2895; MacKay and Shiu 1981)

Density: 0.7733 ; liquid at environmental temperatures

(Buckingham 1982, V3:3895)

Vapor Pressure: $8.98 \times 10^{-5}$ to $9.17 \times 10^{-4} \mathrm{kPa}$ (MacKay and Shiu 1981) $\left(8.98 \times 10^{-7}\right.$ to $\left.9.17 \times 10^{-6} \mathrm{~atm}\right)$

Solubility: $6.3 \times 10^{-3} \mathrm{mg} / \mathrm{L}$ (Mackay and Shiu 1981; Coates et al. 1985)

$9.0 \times 10^{-4} \mathrm{mg} / \mathrm{L}$ (MacKay and Shiu 1981; Sutton and Calder 1974)

$2.110^{-5} \mathrm{mg} / \mathrm{L}$ (Coates et al. 1985)

Henry's Law Constant: $3.24 \times 10^{-2}$ to $2.26 \times 10^{-1}$ atm•mol (Mackay and Shiu 1981)

$\mathrm{K}_{\mathrm{oc}}$ : 47 to 387 (Nathwani and Phillips 1977)

$\mathrm{K}_{\mathrm{o} / \mathrm{w}}: 1.78 \times 10^{8}$ (Nathwani and Phillips 1977)

Adsorption: $56 \%$ of a $100-\mu \mathrm{g} / \mathrm{L}$ solution in seawater adsorbed onto bentonite clay (Meyer and Quinn 1973)

$<1 \%$ of a $100-\mu \mathrm{g} / \mathrm{L}$ solution in seawater adsorbed onto marine sediments that contained $<1 \%$ organic carbon (Meyer and Quinn 1973)

\section{Silty Clay $\quad \underline{\text { Sandy Loam } \quad \text { Silt Loam }}$}

$\begin{array}{lrrr}\mathrm{pH} \text { H Content } \% & 5.4 & 5.1 & 4.3 \\ \text { Org } & 9.4 & 5.8 & 0.6 \\ \text { Sand } \% & 6.7 & 72.7 & 43.7 \\ \text { Silt } \% & 47.9 & 23.7 & 48.9 \\ \text { Clay } \% & 45.4 & 3.6 & 7.4\end{array}$

Spiked hexadecane 1-100 ppm into Alberta crude oil, batch test $1,000 \mathrm{~g}$ soil/L of liquid

$\begin{array}{lccc}\text { Freund lich K } & 36.4 & 4.37 & 0.271 \\ \text { Freund lich } 1 / \mathrm{n} & 0.68 & 1.21 & 1.10 \\ \mathrm{~K}_{\text {oc }} & 38.7 & 75.3 & 46.7\end{array}$

on 1 y $60-80 \%$ of adsorbed hexadecane desorbed off soils into water (Nathwani and Phillips 1977) 


\section{Heptadecane}

$\mathrm{H}_{3} \mathrm{C}\left(\mathrm{CH}_{2}\right)_{15} \mathrm{CH}_{3}$

CAS No. 629-78-7

Melting Point: $22^{\circ} \mathrm{C}$ (Buckingham 1982, V3:2852)

Boiling Point: $303^{\circ} \mathrm{C}$ (Buckingham 1982, V3:2852)

Density: $0.7780 \mathrm{~g} / \mathrm{cm}^{3}$; solid at most environmental temperatures (Buck ingham 1982, V3:2852)

$\mathrm{K}_{\mathrm{o}} / \mathrm{w}: 3.16 \times 10^{8}$ (Wakeham et a1. 1983)

$6.17 \times 10^{8}$ (Coates et al. 1985)

Solubility: $6 \times 10^{-6} \mathrm{mg} / \mathrm{L}$ (Coates et al. 1985) 
2-methylnonane

$\left(\mathrm{H}_{3} \mathrm{C}\right)_{2} \mathrm{CH}\left(\mathrm{CH}_{2}\right)_{6} \mathrm{CH}_{3}$

CAS No. $871-83-0$

Synonym: isodecane

Melting Point: $-74.7^{\circ} \mathrm{C}$ (Buckingham 1982, V4:3958)

Boiling Point: $166.8^{\circ} \mathrm{C}$ (Buckingham 1982, V4:3958)

Density: $0.7281 \mathrm{~g} / \mathrm{cm}^{3} ;$ liquid at environmental temperatures (Buckingham 1982, V4:3958)

Solubility: $0.074 \mathrm{mg} / \mathrm{L}$ (calculated, not measured) (Coates et al. 1985)

$\mathrm{K}_{\mathrm{o} / \mathrm{w}}: 8.2 \times 10^{4}$ (calculated, not measured) (Coates et al. 1985) 
Undecane

$\mathrm{H}_{3} \mathrm{C}\left(\mathrm{CH}_{2}\right)_{9} \mathrm{CH}_{3}$

CAS No. 1120-21-4

Freezing Point: $-25.6^{\circ} \mathrm{C}$ (Buckingham 1982, V5:5661)

Boiling Point: $196^{\circ} \mathrm{C}$ (Buckingham 1982, V5:5661)

Density: $0.7402 \mathrm{~g} / \mathrm{cm}^{3}$; liquid at environmental temperatures (Buckingham 1982, V5:5661)

Vapor Pressure: $5.22 \times 10^{-2} \mathrm{kPa}\left(5.22 \times 10^{-4} \mathrm{~atm}\right)$ (MacKay and Shiu 1981)

Solubility: $0.044 \mathrm{mg} / \mathrm{L}$ (Mackay and Shiu 1981)

$0.014 \mathrm{mg} / \mathrm{L}$ (Coates et al. 1985)

Henry's Law Constant: $1.85 \mathrm{~atm} \bullet \mathrm{m}^{3} / \mathrm{mol}$ recommended value $1.855 \neq 0.76 \mathrm{~atm} \bullet \mathrm{m}^{3} / \mathrm{mol}$ (Mackay and Shiu 1981)

$K_{0 / w}: 3.80 \times 10^{5}$ (Coates et al. 1985)

$5.50 \times 10^{6}$ (Hawker and Connell 1989) 


\section{Octadecane}

$\mathrm{H}_{3} \mathrm{C}\left(\mathrm{CH}_{2}\right)_{16} \mathrm{CH}_{3}$

CAS N0. 593-45-3

Melting Point: $28^{\circ} \mathrm{C}$; a solid at temperatures below $82^{\circ} \mathrm{F}$ (Buckingham 1982, $\mathrm{V} 4: 4351$ )

Boiling Point: $305-307^{\circ} \mathrm{C}$ (Buckingham 1982, V4:4351)

Water Solubility: $2 \times 10^{-3}$ to $6 \times 10^{-3} \mathrm{mg} / \mathrm{L}$ (Coates et al. 1985)

Henry's Law Constant: very low (Sutton and Calder 1974)

$\mathrm{K}_{\mathrm{o} / \mathrm{w}}: 2.09 \times 10^{9}$ (Coates et al. 1985)

$\mathrm{K}_{\text {oc }}$ : $\quad 1.29 \times 10^{9}$ (Computed using $\mathrm{K}_{\mathrm{OC}}=1.00 \log \mathrm{K}_{\mathrm{O} / \mathrm{w}}-0.21$ ) 
2-methyl-5-propylnonane

$$
\underset{\mathrm{C}_{3} \mathrm{C}\left(\mathrm{CH}_{2}\right)_{3} \mathrm{CH}\left(\mathrm{CH}_{2}\right)_{2} \mathrm{CHCH}_{3}}{\mathrm{CH}_{3}}
$$

CAS No. = unknown

Compound not found in the literature 
A.2 ALCOHOLS

$\mathrm{C}-\mathrm{OH}$

A. 15 
Ethyl Alcohol

$\mathrm{C}_{2} \mathrm{H}_{5} \mathrm{OH}$

CAS No. $64-17-5$

Synonym: ethanol

$\mathrm{K}_{\mathrm{o} / \mathrm{w}}: 0.49$ (Strenge and Peterson 1989)

0.49 (Hansch and Leo 1985)

Water Solubility: $280 \mathrm{~g} / \mathrm{L}$ (Strenge and Peterson 1989), miscible (Riddick et al. 1986)

$\mathrm{K}_{\mathrm{OC}}: 0.30$ (Strenge and Peterson 1989)

16 (Syracuse Research Corp. 1988)

Henry's Law Constant: $1.2 \times 10^{-5} \mathrm{~atm} \cdot \mathrm{m}^{3} / \mathrm{mol}$ (Strenge and Peterson 1989)

$5.20 \times 10^{-6} \mathrm{~atm} \bullet \mathrm{m}^{3} / \mathrm{mol}$ (Snider and Dawson 1985)

Vapor Pressure: $59 \mathrm{~mm} \mathrm{Hg}$ (Strenge and Peterson 1989)

Degradation Rate: $t 1 / 2<1$ day in river water (Apoteker and Thevenot 1983) degrades rapidly $<1$ day in silty clay loam

(Griebel and Owens 1972) 
Butyl Alcohol

$\mathrm{H}_{3} \mathrm{C}\left(\mathrm{CH}_{2}\right)_{3} \mathrm{OH}$

CAS No. $71-36-3$

Synonyms: n-butyl alcohol

1-butanol

$\mathrm{K}_{\mathrm{o} / \mathrm{w}}: 1.224$ (Hansch and Leo 1985)

5.6 (Strenge and Peterson 1989)

0.88 (Verschueren 1983)

Core Sorption: Freundlich $1 / \mathrm{N}=1.16$ at $65^{\circ} \mathrm{C}, 500$ to $50,000 \mathrm{mg} 1$-butanol/L; Freund lich $1 / \mathrm{N}=1.11$ at $93^{\circ} \mathrm{C}, 500$ to $50,000 \mathrm{mg} 1$-butanol $/ \mathrm{L}$, all on a cleaned core of Cottage Grove sandstone (Donaldson et al. 1975)

Montmorillonite Sorption: see Stul et al. (1979)

Water Solubility: $74 \mathrm{~g} / \mathrm{L}$ at $25^{\circ} \mathrm{C}$ (calculated) (Merck Index 1976) $63.2 \mathrm{~g} / \mathrm{L}$ at $25^{\circ} \mathrm{C}$ (Tewari et al. 1982) $79 \mathrm{~g} / \mathrm{L}$ (Strenge and Peterson 1989)

$K_{\text {oc }}: 72$ (calculated) (Syracuse Research Corp. 1988) 4.7 (Strenge and Peterson 1989)

Henry's Law Constant: $8.81 \times 10^{-6} \mathrm{~atm} \cdot \mathrm{m}^{3} / \mathrm{mol}$ (Buttery et al. 1969) $4.8 \times 10^{-6} \mathrm{~atm} \bullet \mathrm{m}^{3} / \mathrm{mol}$ (Strenge and Peterson 1989)

Degradation Rate: $t 1 / 2 \sim 6$ days in seawater when $3-10 \mathrm{mg} / \mathrm{L}$ butyl alcohol-laden wastewater mixed (Price et al. 1974)

$\mathrm{t} 1 / 2 \sim 4$ days in freshwater when $3 \mathrm{mg} / \mathrm{L}$ added (Hammerton 1955) t1/2 = 52 days in soil (Strenge and Peterson 1989) 


\section{2-Butoxyethanol}

$\mathrm{H}_{3} \mathrm{C}\left(\mathrm{CH}_{2}\right)_{3} \mathrm{OCH}_{2} \mathrm{CH}_{2} \mathrm{OH}$

CAS No. 111-76-2

Synonyms: ethylene glycol mono-n-butyl ether butyl cellosolve

$K_{o / w}: 6.761$ (Hansch and Leo 1985)

Henry's Law Constant: $2.08 \times 10^{-7} \mathrm{~atm} \bullet \mathrm{m}^{3} / \mathrm{mol}$

(Syracuse Research Corp. recommended)

Water Solubility: miscible (Riddick et al. 1986); $4.5 \mathrm{~g} / \mathrm{L}$ at $25^{\circ} \mathrm{C}$ (Dorigan et al. 1976)

$K_{\text {oC }}$ : 67 (calculated) (Syracuse Research Corp. 1988) 
2-Propanol

$\mathrm{H}_{3} \mathrm{CCHOHCH}_{3}$

CAS No. $6763-0$

Synonyms: isopropyl alcohol

isopropanol

secondary propyl alcohol

$\mathrm{K}_{\mathrm{o} / \mathrm{w}}: 1.122$ (Hansch and Leo 1985)

Water Solubility: miscible (Riddick et al. 1986)

$\mathrm{K}_{\mathrm{oc}}: 25$ (calculated) (Syracuse Research Corp. 1988)

Henry's Law Constant: $7.89 \times 10^{-6} \mathrm{~atm} \bullet \mathrm{m}^{3} / \mathrm{mol}$ (Snider and Dawson 1985)

Degradation Rate: in seawater that has isopropanol (3-10 $\mathrm{mg} / \mathrm{L})-1$ aden wastewater added, $t 1 / 2 \approx 12$ days (Price et al. 1974) 
Benzyl Alcohol

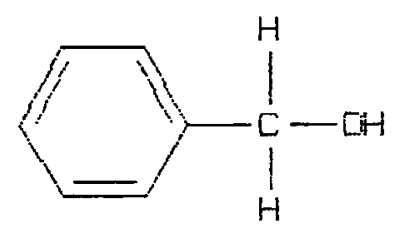

CAS No. 100-51-6

Synonyms: benzenemethanol

phenylmethanol

$\alpha$-hydroxytoluene

$K_{0 / W}: 12.30$ (Hansch and Leo 1981)

Soil Sorption: Eastern Australian Red-Brown Earth, 1.09\% organic carbon, $\mathrm{pH} 8.0,10 \mathrm{mg}$ benzl alcohol/L in influent solution;

Freundlich adsorption of $0.17 \mathrm{mg} / \mathrm{g}$ (Briggs 1981)

Water Solubility: $40 \mathrm{~g} / \mathrm{L}$ at $25^{\circ} \mathrm{C}$ (Ringk and Theimer 1978) 


\section{A.3 ETHERS \\ C-O-C}


Dimethoxymethane

$\mathrm{H}_{3} \mathrm{COCH}_{2} \mathrm{OCH}_{3}$

CAS No. $109-87-5$

Synonyms: formaldehyde dimethyl acetal methylal

formal

Melting Point: $105^{\circ} \mathrm{C}$ (Buckingham 1982, V2:2048)

Boiling Point: $42^{\circ} \mathrm{C}$ (Buckingham 1982, V2:2048) 
Tetrahydrofuran<smiles>[3H]C1CCCCC1(C)O</smiles>

CAS No. 109-99-9

Synonyms: diethylene oxide tetramethylene oxide oxolane

$\mathrm{K}_{\mathrm{o} / \mathrm{W}}: 2.88$ (Hansch and Leo 1979)

Water Solubility: miscible (Dunlop 1966)

Melting Point: $-65^{\circ} \mathrm{C}$ (Grasselli and Ritchey 1975, III:f386)

Boiling Point: $67^{\circ} \mathrm{C}$ (Grasselli and Ritchey 1975, III:f386)

Density: 0.889 at $20^{\circ} \mathrm{C}$ (Grasse $11 \mathrm{i}$ and Ritchey 1975, III:f386) 


\section{A. 4 ESTERS}

carboxylic acid esters

$$
F-C
$$

phthalic acid esters

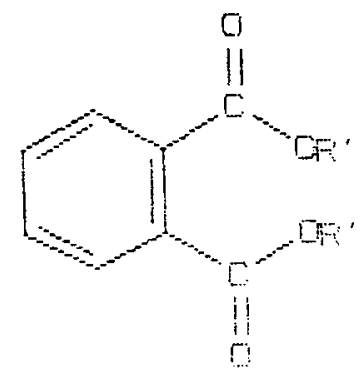




\section{Methyl Formate}

$\mathrm{HCOOCH}_{3}$

CAS No. 107-31-3

Synonyms: formic acid methyl ester

Freezing Point: $-99^{\circ} \mathrm{C}$ (Buckingham 1982, V4:3858)

Boiling Point: $31.5^{\circ} \mathrm{C}$ (Buckingham 1982, V4:3858)

Very flammable; flash point at $\sim 19^{\circ} \mathrm{C}$ (Buckingham 1982, V4:3858)

Density: 0.974 at $20^{\circ} \mathrm{C}$ (Grasselli and Ritchey 1975, III:f297)

Water Solubility: very soluble (Grasselli and Ritchey 1975, III:f297) 
CAS No. $84-74-2$

Synonyoms: n-butyl phthalate<smiles>CCCCCCC(C)C(C)COC(=O)c1ccccc1C(=O)OCC(C)C</smiles>
elaol DBP

1,2-benzenedicarboxylic acid dibutyl ester phthalic acid dibutyl ester

$\mathrm{K}_{\mathrm{o} / \mathrm{w}}: 52,490$ (Hansch and Leo 1985)

40,000 (Strenge and Peterson 1989)

Soil Sorption: Natural seawater with 19 to $3,930 \mu$ g dibutyl phthalate/L, $\sim 1 \%$ organic content, $25^{\circ} \mathrm{C}$ (Sullivan et al. 1982)

\section{Material}

Texas Shelf Montmorillonite

Kaolinite

Ca-Montmorillonite

\section{Freundlich Adsorption, $\mu \mathrm{g}$}

$3,930 \mu \mathrm{g} / \mathrm{L}$ solution - $44 \mu \mathrm{g}$ adsorption $22 \mu \mathrm{g} / \mathrm{L}$ solution - $1.9 \mu \mathrm{g}$ adsorption $3,840 \mu \mathrm{g} / \mathrm{L}$ solution - $20 \mu \mathrm{g}$ adsorption $19 \mu \mathrm{g} / \mathrm{L}$ solution - $4 \mu \mathrm{g}$ adsorption

$3,440 \mu \mathrm{g} / \mathrm{L}$ solution - $4 \mu \mathrm{g}$ adsorption $27 \mu \mathrm{g} / \mathrm{L}$ solution - $36 \mu \mathrm{g}$ adsorption

Water Solubility: $11.2 \mathrm{mg} / \mathrm{L}$ at $25^{\circ} \mathrm{C}$ (Howard et al. 1985)

$400 \mathrm{mg} / \mathrm{L}$ at $25^{\circ} \mathrm{C}$ (Verschueren 1983)

$K_{\mathrm{oc}}: 1,800$ (Russell and McDuffie 1986)

170,000 (Strenge and Peterson 1989)

Henry's Law Constant: $1.81 \times 10^{-6}$ atm $\mathrm{m}^{3} / \mathrm{mol}$ at $23^{\circ} \mathrm{C}$ (Atlas et al. 1983) $2.8 \times 10^{-7} \mathrm{~atm} \cdot \mathrm{m}^{3} / \mathrm{mol}$ (Strenge and Peterson 1989) 
Degradation Rate: $t 1 / 2<14$ days in freshwater sediment (Johnson et al. 1984)

$\mathrm{t} 1 / 2=15.4$ days soil/activated sludge $(\mathrm{pH}=7)$ after 14-day acclimation period (Sugatt et al. 1984)

$\mathrm{t} 1 / 2=7$ to 14 days in freshwater sediment (pond), mixed 9 parts water, 1 part sediment (Johnson and Lulves 1975; Johnson et al. 1984)

$\mathrm{t} 1 / 2=1$ to 3 days in freshwater at $0.5 \mathrm{mg} / \mathrm{L}$ concentration after 2- to 7- day acclimation period (Walker et al. 1984)

t $1 / 2=2$ to 4 days in freshwater/sediment environment at $0.5 \mathrm{mg} / \mathrm{L}$ loading of phthalate (Walker et al. 1984)

$\mathrm{t} 1 / 2=60$ to 70 days in sandy soil, $\mathrm{pH}=6.2$ in dissolved organic contents $=1.4 \%$ when original conc. $1,000 \mathrm{mg} / \mathrm{L}$ phthalate (Inman et al. 1984)

$\mathrm{t} 1 / 2=30$ to 50 days in silt loam saturated with water containing $1.96 \%$ disolved organic carbon when original conc. $1,000 \mathrm{mg} / \mathrm{L}$ phthalate (Inman et al. 1984) 


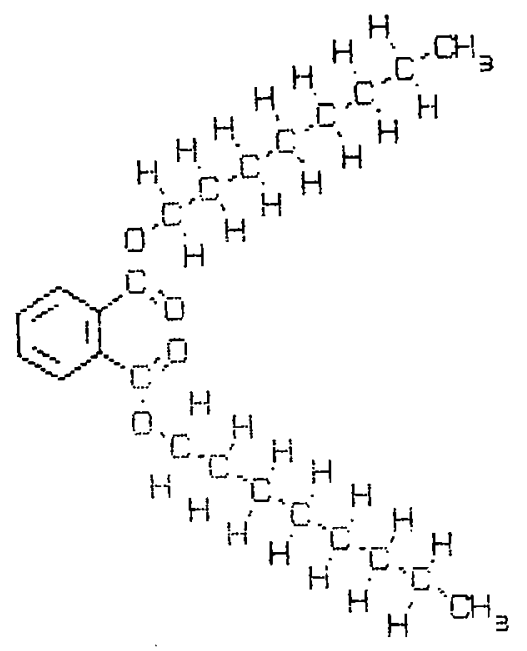

CAS No. $117-84-0$

Synonym: 1,2-benzenedicarboxylic acid di-n-octyl ester

$\mathrm{K}_{\mathrm{o} / \mathrm{w}}: 165,900$ (Hansch and Leo 1985) (not a recommended value) $7.4 \times 10^{9}$ (Strenge and Peterson 1989)

Water Solubility: $3 \mathrm{mg} / \mathrm{L}$ at $25^{\circ} \mathrm{C}$ (Wolfe et al. 1980)

$0.34 \mathrm{mg} / \mathrm{L}$ (Strenge and Peterson 1989)

$0.285 \mathrm{mg} / \mathrm{L}$ (Verschueren 1983)

$K_{\text {oc }}: 2,385$ (Syracuse Research Corp. 1988) calculated value $3.6 \times 10^{9}$ (Strenge and Peterson 1989)

Henry's Law Constant: $4.45 \times 10^{-7}$ atm・ $3 / \mathrm{mol}$ at $25^{\circ} \mathrm{C}$, (Syracuse Research Corp. 1988)

$5.5 \times 10^{-6} \mathrm{~atm} \mathrm{~m}^{3} / \mathrm{mol}$ (Strenge and Peterson 1989)

$1 \times 10^{-6} \mathrm{~atm} \cdot \mathrm{m}^{3} / \mathrm{mol}$ (Petrasek et al. 1983)

Degradation Rate: $t 1 / 2=5$ days in freshwater/sediment environment with initial concentration $5 \mathrm{mg} / \mathrm{L}$ (Sanborn et al. 1975) 
Bis(2-ethylhexyl)phthalate

CAS No. $117-81-7$

Synonyms: di(2-ethylhexyl)phthalate

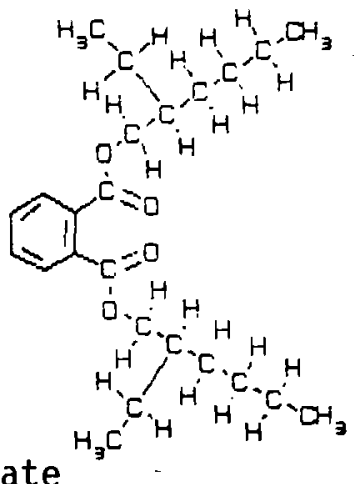

dioctyl phthalate

1,2-benzenedicarboxylic acid bis(2-ethylhexyl)ester octoil

$\mathrm{K}_{\mathrm{o} / \mathrm{w}}: 128,800$ (OECD 1981)

$4.1 \times 10^{9}$ (Strenge and Peterson 1989)

Soil Sorption: Linear isotherm on kaolinite, montmorillonites, and sediments;

more adsorption than dibutyl phthalate, less adsorption in

distilled water than in seawater (Sullivan et al. 1981, 1982)

Summary of phthalate sorption results in seawater at $25^{\circ} \mathrm{C}$ (Sullivan et al. 1982).

\begin{tabular}{|c|c|c|c|c|}
\hline Adsorbate & Adsorbent & $\begin{array}{r}\text { Wt. Range of } \\
\text { Adsorbent, } \mathrm{mg}\end{array}$ & $\begin{array}{c}\text { Initial } \\
\text { Phthalate } \\
\text { conc., } \\
\mu \mathrm{g} / \mathrm{L} \\
\end{array}$ & K \\
\hline $\begin{array}{l}\text { BEHP } \\
{\left[{ }^{14} \mathrm{C}\right] \mathrm{BEHP}} \\
{[14 \mathrm{C}] \mathrm{BEHP}} \\
\text { BEHP } \\
{[14 \mathrm{C}] \mathrm{BEHP}} \\
{[14 \mathrm{C} \text { BEHP }} \\
{[14 \mathrm{C}] \mathrm{BEHP}} \\
{[14 \mathrm{C}] \mathrm{BEHP}}\end{array}$ & $\begin{array}{l}\text { montmorillonite } \\
\text { montmorillonite } \\
\text { kaolinite } \\
\text { calcite } \\
\text { calcite } \\
\text { calcium montmorillonite } \\
\text { sediment } \\
\text { montmorillonite } \\
\text { (distilled water) }\end{array}$ & $\begin{array}{c}6-80 \\
5-77 \\
6-126 \\
23-178 \\
3-210 \\
6-80 \\
11-83 \\
6-80\end{array}$ & $\begin{array}{r}377 \\
13 \\
13 \\
208 \\
7 \\
16 \\
6 \\
9\end{array}$ & $\begin{aligned} 11.4 & \pm 1.1 \\
12.7 & \pm 0.8 \\
12.1 & \pm 1.8 \\
1.8 & \pm 0.8 \\
1.8 & \pm 0.4 \\
1.3 & \pm 0.3 \\
5.1 & \pm 1.0 \\
4.6 & \pm 0.3\end{aligned}$ \\
\hline $\begin{array}{l}\mathrm{DBP} \\
{\left[{ }^{14} \mathrm{C}\right] \mathrm{DBP}} \\
\mathrm{DBP} \\
{\left[{ }^{14} \mathrm{C}\right] \mathrm{DBP}} \\
\mathrm{DBP} \\
{\left[{ }^{14} \mathrm{C}\right] \mathrm{DBP}} \\
\mathrm{DBP} \\
{\left[{ }^{14} \mathrm{C}\right] \mathrm{DBP}} \\
\text { DBP }\end{array}$ & $\begin{array}{l}\text { montmorillonite } \\
\text { montmorillonite } \\
\text { kaolinite } \\
\text { kaolinite } \\
\text { calcite } \\
\text { calcite } \\
\text { calcium montmorillonite } \\
\text { calcium montmorillonite } \\
\text { sediment }\end{array}$ & $\begin{array}{l}55-687 \\
6-58 \\
25-621 \\
4-64 \\
30-435 \\
8-94 \\
26-542 \\
7-90 \\
9-79\end{array}$ & $\begin{array}{r}3,930 \\
22 \\
3,840 \\
19 \\
3,710 \\
25 \\
3,440 \\
27 \\
19\end{array}$ & $\begin{array}{l}0.044 \pm 0.005 \\
0.019 \pm 0.002 \\
0.020 \pm 0.003 \\
0.004 \pm 0.001 \\
0.005 \pm 0.001 \\
0.010 \pm 0.002 \\
0.004 \pm 0.001 \\
0.036 \pm 0.017 \\
0.149 \pm 0.017\end{array}$ \\
\hline $\begin{aligned} H P & =B \\
P & =D \\
& =P c \\
& =0\end{aligned}$ & $\begin{array}{l}t \mathrm{t}= \\
\text { eaw }\end{array}$ & & & the $n$ \\
\hline
\end{tabular}


For kaolinite, calcite, and Ca-montmorillonite, adsorption = desorption over 12 hours.

Water Solubility: $0.40 \mathrm{mg} / \mathrm{L}$ at $25^{\circ} \mathrm{C}$ (Wolfe et al. 1980)

$0.34 \mathrm{mg} / \mathrm{L}$ at $25^{\circ} \mathrm{C}$ (Howard et a 1.1985 )

$0.4 \mathrm{mg} / \mathrm{L}$ (Strenge and Peterson 1989)

$\mathrm{K}_{\mathrm{oc}}: 87,000$ (Strenge and Peterson 1989)

Henry's Law Constant: $1.47 \times 10^{-5} \mathrm{~atm} \cdot \mathrm{m}^{3} / \mathrm{mol}$ at $25^{\circ} \mathrm{C}$ (Syracuse Research Corp. 1988) $4.4 \times 10^{-7} \mathrm{~atm} \cdot \mathrm{m}^{3} / \mathrm{mol}$ (Strenge and Peterson 1989)

Degradation Rate: $t 1 / 2 \sim 5$ days in seawater near Japanese factory (Haltori et al. 1975)

t1/2 14 days in seawater away from pollution (Haltori et al. 1975)

t1/2 14 days in river water in Japan

(Haltori et al. 1975)

$\mathrm{t} 1 / 2=15$ to $>30$ days in freshwater pond with $1 \mathrm{mg} / \mathrm{L}$ starting conc. (Johnson and Lulves 1975)

$t 1 / 2=<7$ to 30 days in seawater when initial conc. $=0.001$ to $0.1 \mathrm{mg} / \mathrm{L}$ (Perez et al. 1985)

$\mathrm{t} 1 / 2=28$ days in eutrophic lake at conc. $10^{-6}$ to $1 \mathrm{mg} / \mathrm{L}$ (Rubin et al. 1982; Subboa-Rao et al. 1982)

$\mathrm{t} 1 / 2 \gg 14$ days in freshwater/sediment at 1-70 $\mathrm{mg} / \mathrm{L}$ (Schwartz et al. 1979)

$\mathrm{t} 1 / 2<140$ days in sandy loam inoculated with sludge with 2-20 $\mathrm{mg} / \mathrm{L}$ phthalate (Fairbanks et al. 1985)

$\mathrm{t} 1 / 2 \sim 15$ garden soil at $60 \%$ moisture, $\mathrm{pH} 8.2,500 \mathrm{mg} / \mathrm{L}$ phthalate (Shanker et al. 1985) 


\section{Butyl Benzyl Phthalate}

CAS No. $85-68-7$<smiles>CCCC(C)CC(=O)c1ccccc1C(=O)Oc1ccccc1</smiles>

$\mathrm{K}_{\mathrm{O} / \mathrm{w}}: 81,280$ (Hansch and Leo 1985)

104.78 (Verschueren 1983)

Soil Sorption: Three soils with organic carbon contents of 0.70 to $2.0 \%$, influent concentration between 0 and $1.0 \mathrm{mg} / \mathrm{L}$. Freund $1 \mathrm{ich}$ adsorption from 68 to $350 \mathrm{mg}$ butyl benzyl phthalate (Gledhill et a1. 1980)

Water Solubility: $2.69 \mathrm{mg} / \mathrm{L}$ at $25^{\circ} \mathrm{C}$ (Howard et al. 1985)

$2.90 \mathrm{mg} / \mathrm{L}$ at $25^{\circ} \mathrm{C}$ (Verschueren 1983)

$K_{\mathrm{oC}}: 17,000$ (Russe 11 and McDuffie 1986)

Henry's Law Constant: $1.26 \times 10^{-6} \mathrm{~atm} \bullet \mathrm{m}^{3} / \mathrm{mol}$ (Syracuse Research Corp. 1988) at $25^{\circ} \mathrm{C}$ (calculated value)

Degradation Rate: $t 1 / 2<2$ days in Mississippi River water when added at $1 \mathrm{mg} / \mathrm{L}$ conc. (Saeger and Tucker 1976) 


\section{A.5 ALDEHYDES \\ $-\mathrm{C}_{\mathrm{H}}{ }^{1 /}$}




\section{Butyraldehyde}<smiles>CCC=O</smiles>

CAS No. $123-72-8$

Synonym: butanal

$\mathrm{K}_{\mathrm{o} / \mathrm{w}}: 7.586$ (Hansch and Leo 1985)

Water Solubility: 30 to $71 \mathrm{~g} / \mathrm{L}$ at $25^{\circ} \mathrm{C}$ (Smith and Bonner 1951)

$K_{\text {oc }}$ : 9.4 (Syracuse Research Corp. 1988) calculated value

Henry's Law Constant: $1.15 \times 10^{-4} \mathrm{~atm} \bullet \mathrm{m}^{3} / \mathrm{mol}$ at $25^{\circ} \mathrm{C}$ (Buttery et al. 1969)

Degradation Rate: degrades fast in sewage (in BIODEG summary database, no reference given) 
Benzaldehyde

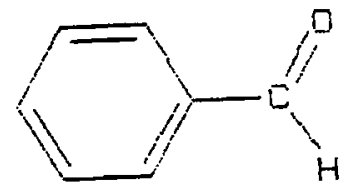

CAS No. 100-52-7

Synonym: benzoic aldehyde

$K_{o / w}: 30.2$ (Hansch and Leo 1981)

Water Solubility: $3 \mathrm{~g} / \mathrm{L}$ at $25^{\circ} \mathrm{C}$ (Sherman 1978).

Degradation Rate: degrades fast in sewage (in BIODEG summary database, no reference given) 


\section{A.6 KETONES \\ ${ }_{1} \mathrm{c}=0$}


Acetone

$\left(\mathrm{CH}_{3}\right)_{2} \mathrm{C}=0$

CAS No. 67-64-1

Synonyms: $\beta$-ketopropane 2-propanone dimethyl ketone

$\mathrm{K}_{\mathrm{o} / \mathrm{w}}: 0.575$ (Hansch and Leo 1985)

0.581 (Strenge and Peterson 1989)

Soil Sorption: No sorption on montmorillonite, kaolinite, stream sediments, local stream algae, and local stream mold (Rathbun et al. 1982)

Water Solubility: miscible (Riddick et al. 1986), $1,000 \mathrm{~g} / \mathrm{L}$ (Strenge and Peterson 1989)

$\mathrm{K}_{\mathrm{oc}}$ : 18 (Syracuse Research Corp. 1988) calculated value 2.2 (Strenge and Peterson 1989)

Henry's Law Constant: $3.88 \times 10^{-5} \mathrm{~atm} \bullet \mathrm{m}_{3}^{3} / \mathrm{mol}$ (Snider and Dawson 1985)

$2.10 \times 10^{-5} \mathrm{~atm} \cdot \mathrm{m}^{3} / \mathrm{mol}$ (Strenge and Peterson 1989)

Degradation Rate: in seawater with $3-10 \mathrm{mg} / \mathrm{L}$ acetone added with wastewater t1/2 7 days (Price et al. 1974)

in soils t1/2 $=4.8$ days (Strenge and Peterson 1989) 
Methyl Ethyl Ketone (MEK)

$\left(\mathrm{CH}_{3}\right)\left(\mathrm{C}_{2} \mathrm{H}_{5}\right) \mathrm{C}=0$

CAS No. $78-93-3$

Synonyms: 2-butanone

2-oxobutane

$\mathrm{K}_{\text {ow }}: 1.069$ (Hansch and Leo 1985)

1.9 (Strenge and Peterson 1989)

Core Sorption: Freundlich $1 / \mathrm{N}=1.00$ at $60^{\circ} \mathrm{C}, 500$ to 5,000 mg methyl ethy 1 ketone $/ \mathrm{L}_{\text {; }}$ Freundlich $1 / \mathrm{N}=0.99$ at $38^{\circ} \mathrm{C}, 500$ to $5,000 \mathrm{mg}$ methyl ethyl ketone/L, all on a cleaned core of Cottage Grove sandstone (Donaldson et al. 1975)

Water Solubility: $223 \mathrm{~g} / \mathrm{L}$ at $25^{\circ} \mathrm{C}$ (Taft et al. 1985)

$270 \mathrm{~g} / \mathrm{L}$ (Strenge and Peterson 1989)

$\mathrm{K}_{\text {oc }}$ : 5.2 (Syracuse Research Corp. 1988) calculated value

4.5 (Strenge and Peterson 1989)

Henry's Law Constant: $5.59 \times 10^{-5} \mathrm{~atm} \bullet \mathrm{m}^{3} / \mathrm{mol}$ (Park et al. 1987)

$2.7 \times 10^{-5} \mathrm{~atm} \bullet \mathrm{m}^{3} / \mathrm{mol}$ (Strenge and Peterson 1989)

Degradation Rate: $t 1 / 2 \sim 7.5$ days in seawater at 3-10 mg/L MEK when wastewater laden with MEK added (Price et al. 1974)

$\mathrm{t} 1 / 2 \leq 1$ day in Polish river water at $10 \mathrm{mg} / \mathrm{L}$ loading, with 200 to $400 \mathrm{ppm}$ up to 9 days (Dojlido 1979)

$\mathrm{t} 1 / 2$ = 16 days in soil (Strenge and Peterson 1989) 
Methyl n-Butyl Ketone

methyl buty1 ketone<smiles>CCC(C)C(C)=O</smiles>

CAS No. 591-78-6

Synonym: 2-hexanone

$K_{0 / w}: 23.99$ (Hansch and Leo 1981)

24 (Strenge and Peterson 1989)

Water Solubility: $17.5 \mathrm{~g} / \mathrm{L}$ at $20^{\circ} \mathrm{C}$ (Papa and Sherman 1981)

$14 \mathrm{~g} / \mathrm{L}$ (Strenge and Peterson 1989)

$K_{\text {oc }}: 15$ (Strenge and Peterson 1989)

Henry's Law Constant: $1.1 \times 10^{-5} \mathrm{~atm} \cdot \mathrm{m}^{3} / \mathrm{mol}$ (Strenge and Peterson 1989) 
$\underline{\text { MIBK }}$<smiles>CCC(C)=O</smiles>

CAS No. 108-10-1

Synonyms: methyl isobutyl ketone hexanone

4-methy 1-2-pentanone

$\mathrm{K}_{\mathrm{o} / \mathrm{w}}: 15.48$ (Syracuse Reasearch Corp. 1988) calculated value 5.3 (Strenge and Peterson 1989)

Water Solubility: $19 \mathrm{~g} / \mathrm{L}$ (Strenge and Peterson 1989) $19.0 \mathrm{~g} / \mathrm{L}$ (Verschueren 1983)

$\mathrm{K}_{\mathrm{oc}}$ : 19 (Syracuse Reasearch Corp. 1988) calculated value 19 (Strenge and Peterson 1989)

Henry's Law Constant: $1.38 \times 10^{-4} \mathrm{~atm} \bullet \mathrm{m}^{3} / \mathrm{mol}$ at $25^{\circ} \mathrm{C}$ (Syracuse Research Corp. 1988) calculated value

$4.2 \times 10^{-5} \mathrm{~atm} \cdot \mathrm{m}^{3} / \mathrm{mol}$ at $25^{\circ} \mathrm{C}$ (Strenge and Peterson 1989)

Degradation Rate: $t 1 / 2=15$ days in seawater when present at $3-10 \mathrm{mg} / \mathrm{L}$ concentration added to seawater as wastewater

(Price et al. 1974) 
Methyl n-Propyl Ketone<smiles>CCC(C)=O</smiles>

CAS No. 107-87-9

Synonyms: 2-Pentanone ethyl acetone

$K_{0 / w}: 8.129$ (Hansch and Leo 1985)

Water Solubility: $43 \mathrm{~g} / \mathrm{L}$ at $25^{\circ} \mathrm{C}$ (Yalkowsky et al. 1987)

Henry's Law Constant: $6.36 \times 10^{-5} \mathrm{~atm} \bullet \mathrm{m}^{3} / \mathrm{mol}$ (Hine and Mookerjee 1975)

Degradation Rate: biodegrades fast in sewage after system acclimates to presence of compound (in BIODEG summary database, no references given) 


\section{Acetophenone}

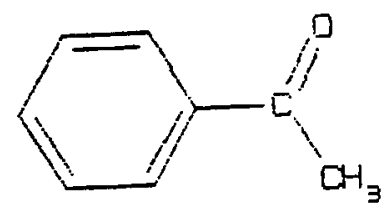

CAS No. $98-86-2$

Synonyms: 1-phenylehanone

phenyl methyl ketone

acetylbenzene

$\mathrm{K}_{\mathrm{o} / \mathrm{w}}: \quad 38.01$ (Hansch and Leo 1985)

48 (Strenge and Peterson 1989)

Selected chemical and physical properties of the sediments and soils

\begin{tabular}{|c|c|c|c|c|c|c|c|c|}
\hline Soil & $(1 \stackrel{\mathrm{pH}}{:} 1)$ & $\begin{array}{c}\text { CEC } \\
\text { meq/106g) }\end{array}$ & $\begin{array}{l}\text { Organic } \\
\text { carbon, } x\end{array}$ & Sand, $x$ & silt, $x$ & Clay, $x$ & $K_{p}(a)$ & $k_{\text {oc }}$ \\
\hline 1 & 7.79 & 23.72 & 2.07 & 3.0 & 41.8 & 55.2 & 0.89 & 43 \\
\hline 2 & 7.44 & 19.00 & 2.28 & 33.6 & 35.4 & 31.0 & g. 56 & 24 \\
\hline 3 & 7.83 & 33.01 & อ. 72 & 6. 2 & 31.2 & 68.6 & 0.68 & 95 \\
\hline 4 & 8.32 & 3.72 & 0.15 & 82.4 & 10.7 & 6.8 & 0.07 & 48 \\
\hline 5 & 8.34 & $12.4 \bar{\theta}$ & 0.11 & 7.1 & 75.6 & 17.4 & 0.09 & 82 \\
\hline 6 & 4.45 & 18.86 & 0.48 & 2.1 & 34.4 & 83.6 & b. 12 & 25 \\
\hline 7 & 7.79 & 11.30 & 0.95 & 15.8 & 48.7 & 35.7 & 6.27 & 28 \\
\hline 8 & 7.76 & 15.43 & 0.66 & 34.6 & 25.8 & 39.5 & 0.30 & 46 \\
\hline 9 & 5.50 & 8.56 & 1.30 & 0.0 & 71.4 & 28.6 & 6. 29 & 22 \\
\hline 10 & 7.80 & 8.33 & 1.88 & 50.2 & 42.7 & $\begin{array}{r}7.1 \\
0.19\end{array}$ & 0.85 & 45 \\
\hline 11 & 7.55 & 8.53 & 1.67 & 26.2 & 52.7 & 21.2 & 0.53 & 31 \\
\hline 12 & 6.70 & 31.15 & 2.38 & 17.3 & 13.6 & 69.1 & 0.68 & 29 \\
\hline 13 & 7.75 & 20.86 & 1.48 & 1.6 & 55.4 & 42.9 & 0.66 & 45 \\
\hline 14 & 6.35 & 3.72 & 1.21 & 67.6 & 13.9 & 18.6 & 0.44 & 36 \\
\hline
\end{tabular}

(a) Modified Freundlich partition coefficent, $1 / n=1, K_{p}=0.04+0.32$ (organic carbon percentage)

Influent contained $138-1,108 \mathrm{mg}$ acetophenone/L, $25^{\circ} \mathrm{C}$ (Khan et al. 1979), sorption correlates with organic carbon content. 
$R_{d}=0.14$ Soil with $11.2 \%$ clay but no other characterization (Gerstl and Mingelgrin 1984)

$R_{d}=0.05$ Soil with $6.9 \%$ clay but no other characterization (Gerstl and Mingelgrin 1984)

$R_{d}=0.37$ Soil with $61.1 \%$ clay but no other characterization (Gerstl and Mingelgrin 1984)

$R_{d}=0.15$ Soil with $23.8 \%$ clay but no other characterization (Gerstl and Mingelgrin 1984)

$R_{d}=0.30$ Soil with $72.5 \%$ clay but no other characterization (Gerstl and Mingelgrin 1984)

$R_{d}=0.22$ Soil with $10.6 \%$ clay but no other characterization (Gerstl and Mingelgrin 1984)

Water Solubility: $6.13 \mathrm{~g} / \mathrm{L}$ at $25^{\circ} \mathrm{C}$ (Southworth and Keller 1986)

$5.5 \mathrm{~g} / \mathrm{L}$ (Strenge and Peterson 1989)

$\mathrm{K}_{\mathrm{oC}}$ : average of 14 soils, 45 (Khan et al. 1979)

23 (Strenge and Peterson 1989), $10^{0.81}$ to $10^{1.26}$

Henry's Law Constant: $1.07 \times 10^{-5} \mathrm{~atm} \cdot \mathrm{m}^{3} / \mathrm{mol}$ at $25^{\circ} \mathrm{C}$ (Mackay et al 1982)

$3.2 \times 10^{-5} \mathrm{~atm} \cdot \mathrm{m}^{3} / \mathrm{mol}$ (Strenge and Peterson 1989)

Degradation Rate: $t 1 / 2=4$ days based on field observations (Dragun 1986)

$$
\begin{aligned}
\mathrm{t} 1 / 2= & 3.6 \text { days based on field observations in soil in The } \\
& \text { Netherlands, redox condition not specified (Zoeteman } \\
& \text { et al. 1981) } \\
\mathrm{t} 1 / 2= & <11 \text { days ( } 4 \text { days) in Ohio River; compound added in } \\
& \text { sewage overall concentration } 20.5 \mathrm{mg} / \mathrm{L}, \text { system } \mathrm{pH} 7.2 \\
& \text { (Ludzack and Ettinger } 1963)
\end{aligned}
$$




\section{A.7 CARBOXYLIC ACIDS}

$$
-\mathrm{C}_{\mathrm{OH}}{ }^{0}
$$


Pelargic Acid perhaps Westinghouse Hanford (1989) used this to mean pelargonic acid, which has the following data

$\mathrm{H}_{3} \mathrm{C}\left(\mathrm{CH}_{2}\right)_{7} \mathrm{COOH}$

CAS No. 112-05-0

Synonym: nonanoic acid

Melting Point: $15^{\circ} \mathrm{C}$ (Buckingham 1982, V4:4310)

Boiling Point: $255^{\circ} \mathrm{C}$ (Buckingham 1982, V4:4310)

Water Solubility: insoluble (Grasselli and Ritchey 1975, II I:n610) 
Hexadecanoic Acid

$\mathrm{H}_{3} \mathrm{C}\left(\mathrm{CH}_{2}\right)_{14} \mathrm{COOH}$

CAS No. $57-10-3$

Synonym: palmitic acid

Melting Point: $64^{\circ} \mathrm{C}$ (Buckingham 1982, V3:2895)

Boiling Point: $390^{\circ} \mathrm{C}$ (Buckingham 1982, V3:2895)

Water Solubility: insoluble (Grasselli and Ritchey 1975, III:h284) 


\section{Benzoic Acid}<smiles>O=C(O)c1ccccc1</smiles>

CAS No. $65-85-0$

$K_{0 / w}: 74.13$ (Chiou et al. 1977)

74 (Strenge and Peterson 1989)

Dissociation Constant: 4.205 (Sarjeant and Dempsey 1979)

(see also Mabey and Mil1 1978)

Soil Sorption: No sorption (Bailey et al. 1968). $25^{\circ} \mathrm{C}$;

Na-montmorillonite, CEC of $87 \mathrm{meq} / 100 \mathrm{~g}$, solution $\mathrm{pH} 6.8$, $100 \mu \mathrm{mol}$ benzoic acid/L; H-montmorillonite, CEC of 73,5 meq/100g, solution $\mathrm{pH} 3.35,100 \mu \mathrm{mol}$ benzoic acid/L

Water Solubility: $2.70 \mathrm{~g} / \mathrm{L}$ at $18^{\circ} \mathrm{C}$ (Chiou et al. 1977; Mackay et al. 1980)

$3.4 \mathrm{~g} / \mathrm{L}$ at $25^{\circ} \mathrm{C}$ (Strenge and Peterson 1989)

$\mathrm{K}_{\mathrm{OC}}: 46$ (Strenge and Peterson 1989)

Henry's Law Constant: $0.287 \times 10^{-5} \mathrm{~atm} \cdot \mathrm{m}^{3} / \mathrm{mol}$ (U.S. EPA 1981)

$1.3 \times 10^{-7} \mathrm{~atm} \bullet \mathrm{m}^{3} / \mathrm{mol}^{1}$ (Strenge and Peterson 1989) 
A.8 AMINES

$-\mathrm{NH}_{2}$ 
Dimethylnitrosamine

$\left(\mathrm{CH}_{3}\right)_{2}{ }^{\mathrm{NNO}}$

CAS No. 62-75-9

Synonyms: n-nitrosodimethylamine

$2,2^{\prime}-($ nitrosoimino)-bisethanol

$2,2^{\prime}$-nitrosiminodiethanol

$\mathrm{K}_{\mathrm{o} / \mathrm{W}}: 0.269$ (Hansch and Leo 1985)

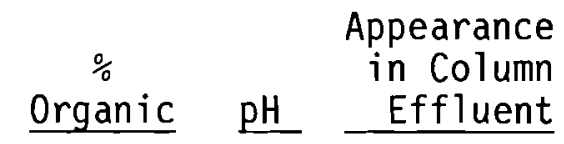

Soil Column Transport: Williamson silt loam

1.9

3.8

5.8

$50 \mathrm{~mL}$

Lima loam

2.5

Scarboro sand

14.8

7.8

$40 \mathrm{~mL}$

Influent: $5 \mathrm{mg}$ dimethylnitrosamine $/ \mathrm{L}, 25^{\circ} \mathrm{C}$.

$30 \mathrm{~mL}$

Conclusion: Dimethylnitrosamine moves as rapidly

in the soil column as chloride (Dean-Raymond and

Alexander 1976). ( no adsorption).

Water Solubility: miscible (Callahan et al. 1979)

$K_{\text {oc }}$ : 12 (Syracuse Research Corp. 1988) calculated value

Henry's Law Constant: $2.63 \times 10^{-7} \mathrm{~atm} \bullet \mathrm{m}^{3} / \mathrm{mol}$ at $20^{\circ} \mathrm{C}$ (Syracuse Research Corp. 1988) calculated value

Degradation Rate: $t 1 / 2=10$ days in uncharacterized soil, $\mathrm{pH} 6.4$ in 1aboratory batch study. Breaks down to methylamine and formaldehyde

(Kaplan and Kaplan 1985)

$17 \%$ percent degradation over a 10-30 day period in a sandy loam with $2.2 \% \mathrm{OC}$ moistened to field capacity and $\mathrm{pH} 4.8$, rate is fast initially, then levels off (Mallik et al. 1981)

no degradation in 2 days in a silt loam (Tate and Alexander 1976) 
N-Methoxymethanamine

$\mathrm{H}_{3} \mathrm{COCH}_{2} \mathrm{NH}_{2}$

CAS No.

Compound not found in the literature. 


\section{3,5-Dimethylpyridine}<smiles>Cc1cncc(C)c1</smiles>

CAS No. 591-22-0

Synonym: 3,5-lutidine

Boiling Point: $171^{\circ} \mathrm{C}$ (Buckingham 1982, V2:2217)

Moderately soluble in water (Buckingham 1982, V2:2217)

Density: 0.942 at $20^{\circ} \mathrm{C}$ (Grasse $11 \mathrm{i}$ and Ritchey 1975, IV:p3725) 
Morpholine<smiles>C1CNCCOC1</smiles>

CAS No. 110-91-8

Synonyms: tetrahydro-2H-1,4-oxazine diethylene imidoxide diethylene oximide

$\mathrm{K}_{\mathrm{o} / \mathrm{W}}: 0.138$ (Hansch and Leo 1985)

Water Solubility: miscible (Nieneker 1971; Riddick et al. 1986)

Henry's Law Constant: $1.41 \times 10^{-7} \mathrm{~atm} \bullet \mathrm{m}^{3} / \mathrm{mol}$ at $25^{\circ} \mathrm{C}$ (Syracuse Research Corp. 1988) calculated value

Degradation Rate: $t 1 / 2 \gg 14$ days (on 1 y $2 \%$ degraded in 14 days) in river mud, $\mathrm{pH}=7.5$ at morpholine conc. of $10-100 \mathrm{mg} / \mathrm{L}$ (Calamari et al. 1980) 


\section{A.9 HALIDES}

$\mathrm{F}, \mathrm{Cl}, \mathrm{Br}$, or $\mathrm{I}$ 
Dichlorofluoromethane

$\mathrm{Cl}_{2} \mathrm{CHF}$

CAS No. $75-43-4$

Synonyms: Freon 21

algofrene type 5

arcton 7

dichloromonofluoromethane

genetron 21

Heavy, colorless gas

Boiling Point: $8.9^{\circ} \mathrm{C}$

Melting Point: $-135^{\circ} \mathrm{C}$

Vapor Pressure: 2 atm at $28.4^{\circ} \mathrm{C}$

Vapor Density: 3.82 compared to 1.00 for air

Use: refrigerant (Sax and Lewis 1989)

Water Solubility: insoluble (Grasselli and Ritchey 1975, III:m326) 
Tetrachloroethylene

$\mathrm{Cl}_{2} \mathrm{C}=\mathrm{CCl}_{2}$

CAS No. $127-18-4$

Synonyms: ethylene tetrachloride perchloroethylene

$\mathrm{K}_{\mathrm{o} / \mathrm{w}}: 2,512$ (Hansch and Leo 1979) 400 (Munz and Roberts 1987)

Soil Sorption: Willamette silt loam; $3.3 \%$ sand, $69 \%$ silt, $26 \%$ clay, $1.6 \%$ organic carbon content; isotherms are linear, Freundlich 1/N is 1.0; calculated $K_{o c}$ was 210 (Chiou et al. 1977)

Materials

Sediment Sorption: $\overline{1 . \text { Granular bentonite clay }}$

2. Dolomite limestone

3. Ottawa sand

4. Peat moss

(Dilling et al. 1975) in $1 \mathrm{mg}$ tetrachloroethylene/L

Lincoln fine sand, $92 \%$ sand, $0.087 \%$ organic carbon, CEC of $3.5 \mathrm{meq} / 100 \mathrm{~g}$ $\mathrm{pH} 6.4,20^{\circ} \mathrm{C}$; Freundlich adsorption was $0.2, \mathrm{~K}_{\mathrm{oc}}$ calculated at 200 , retardation factor of 2.5 (Wilson et al. 1981).

Water Solubility: $200 \mathrm{mg} / \mathrm{L}$ at $25^{\circ} \mathrm{C}$ (Coca and Diaz 1980) $150 \mathrm{mg} / \mathrm{L}$ (Strenge and Peterson 1989)

$\mathrm{K}_{\mathrm{oC}}: 238$ at $25^{\circ} \mathrm{C}$ (Friesel et al. 1984) 360 (Strenge and Peterson 1989)

Henry's Law Constant: $1.84 \times 10^{-2} \mathrm{~atm} \cdot \mathrm{m}^{3} / \mathrm{mol}$ at $25^{\circ} \mathrm{C}$ (Munz and Roberts 1987) $2.6 \times 10^{-2} \mathrm{~atm} \cdot \mathrm{m}^{3} / \mathrm{mole}$ (Strenge and Peterson 1989)

Degradation Rate: $t 1 / 2=300$ days based on field observations in soil/groundwater (Dragun 1986)

t1/2 = 13 days in lab when soil inoculated with microbial flora (Dragun 1986) 
Chloroform

$\mathrm{CHCl}_{3}$

CAS No. 67-66-3

Synonym: Trichloromethane

$\mathrm{K}_{\mathrm{o} / \mathrm{w}}: 93.3$ (Chiou et al. 1977)

93 (Strenge and Peterson 1989)

Freundlich 1/N: 0.77 to 0.95 (Hutzler et al. 1983) (sands, sandy loam, loamy sand and silt loam); no appreciable sorption on soils of lower organic carbon content.

Soil Sorption: Retardation factor $<1.5$ (Wilson et al. 1981); column movement per day in Lincoln fine sand was $41 \%$ in effluent, $54 \%$ volatilized, $5 \%$ degraded with $0.90 \mathrm{mg} \mathrm{CHCl} 3 / \mathrm{L} ; 31 \%$ in effluent, $61 \%$ volatilized and $8 \%$ degraded with $0.25 \mathrm{mg} \mathrm{CHCl}_{3} / \mathrm{L}$ influent; Lincoln fine sand organic content was $0.087 \%, 92 \%$ sand, $5.9 \%$ silt and $2.1 \%$ clay, CEC was $3.5 \mathrm{meq} / 100 \mathrm{~g}$.

Water Solubility: $7.95 \mathrm{~g} / \mathrm{L}$ at $25^{\circ} \mathrm{C}$ (Chiou et al. 1977; Mackay et al. 1980), $8.00 \mathrm{~g} / \mathrm{L}$ at $25^{\circ} \mathrm{C}$ (Wilson et al. 1981) $10.62 \mathrm{~g} / \mathrm{L}$ at $0^{\circ} \mathrm{C}$ (Deshon 1979)

$8.2 \mathrm{~g} / \mathrm{L}$ (Strenge and Peterson 1989)

7.9 to $8.2 \mathrm{~g} / \mathrm{L}$ at $20^{\circ}$ (MacKay and Shiu 1981).

$K_{\text {oc }}: 80$ (Wilson et al. 1981)

31 (Strenge and Peterson 1989)

Henry's Law Constant: $3.67 \times 10^{-3} \mathrm{~atm} \bullet \mathrm{m}^{3} / \mathrm{mol}$ (Gossett 1987)

$2.9 \times 10^{-3} \mathrm{~atm} \bullet \mathrm{m}^{3} / \mathrm{mol}$ (Strenge and Peterson 1989)

$3.8 \pm 0.3 \times 10^{-3} \mathrm{~atm} \bullet \mathrm{m}^{3} / \mathrm{mol}$ (MacKay and Shiu 1981)

Melting Point: $\quad-63.5^{\circ} \mathrm{C}$ (Mackay and Shiu 1981)

Boiling Point: $-61.7^{\circ} \mathrm{C}$ (Mackay and Shiu 1981)

Vapor Pressure: 2.0 to $3.3 \times 10^{1} \mathrm{kPa}\left(0.2\right.$ to $0.3 \mathrm{~atm}$ at $\left.20^{\circ} \mathrm{C}\right)$ (MacKay and Shiu 1981) 
Methylene Chloride

$\mathrm{CH}_{2} \mathrm{Cl}_{2}$

CAS No. $75-09-2$

Synonyms: dichloromethane methylene dichloride Freon 30

$\mathrm{K}_{\mathrm{o} / \mathrm{w}}: 17.38$ (Hansch and Leo 1985) 20 (Strenge and Peterson 1989)

Sediment Sorption:

Materials

$\frac{\text { Materials }}{\text { 1. Granular bentonite clay }}$
2. Dolomite limestone
3. Ottawa sand
4. Peat moss
(Dilling et al. 1975)

Water Solubility: $13.7 \mathrm{~g} / \mathrm{L}$ at $20^{\circ} \mathrm{C}$ (Horvath 1982)

$20 \mathrm{~g} / \mathrm{L}$ (Strenge and Peterson 1989)

$16.7 \mathrm{~g} / \mathrm{L}$ (Verschueren 1983)

$\mathrm{K}_{\mathrm{oc}}: 28$ (Sabljic 1984)

8.8 (Strenge and Peterson 1989)

Henry's Law Constant: $2.19 \times 10^{-3} \mathrm{~atm} \bullet \mathrm{m}^{3} / \mathrm{mol}$ (Gossett 1987)

$2.0 \times 10^{-3} \mathrm{~atm} \cdot \mathrm{m}^{3} / \mathrm{mol}$ (Strenge and Peterson 1989)

Degradation Rate: $t 1 / 2=35$ to 50 days at $5 \mathrm{mg} / \mathrm{L}$ present in Rhine River (Zoeteman et al. 1980)

$\mathrm{t} 1 / 2=3.3$ days (Strenge and Peterson 1989)

Degrades rapidly under anaerobic soil conditions (Cline and Viste 1985) 


\section{A.10 NITRO COMPOUNDS<smiles>CN([O-])[O-]</smiles> 
Methyl nitrate

$\mathrm{H}_{3} \mathrm{CONO}_{2}$

CAS No. $598-58-3$

Synonym: nitric acid methyl ester

Boiling Point: $65^{\circ} \mathrm{C}$ (Buckingham 1982, V4:3930)

Density at $25^{\circ} \mathrm{C}: 1.20$ (Buckingham 1982, V4:3930)

Vapor explodes upon heating

Highly irritant

Melting Point: $-82.3^{\circ} \mathrm{C}$ (Grassel1i and Ritchey 1975, III:n534)

Water Solubility: slightly soluble (Grasselli and Ritchey 1975, III:n534) 
Butyl nitrate

$\mathrm{H}_{3} \mathrm{C}\left(\mathrm{CH}_{2}\right)_{3} \mathrm{ONO}_{2}$

CAS No. $928-45-0$

Synonyms: nitric acid butyl ester n-butylnitrate

Boiling Point: $136^{\circ} \mathrm{C}$ (Buckingham 1982, V1:938)

Flammable liquid; reacts explosively with Lewis acids (aluminum chloride, boron trifluoride, etc.) (Sax and Lewis 1989, VII:642)

Water Solubility: insoluble (Grasselli and Ritchey 1975, III:n530) 


\section{A.11 POLYHYDRIC ALCOHOLS}

Two or more hydroxyl groups (may be substitutions for hydrogens). 
Methoxydiglycol

$\mathrm{H}_{3} \mathrm{COCH}_{2} \mathrm{CH}_{2} \mathrm{OCH}_{2} \mathrm{CH}_{2} \mathrm{OH}$

CAS No. 111-77-3

Synonyms: 2-(2-methoxyethoxy)ethanol diethylene glycol methyl ether diethylene glycol monomethyl ether

Water Solubility: $25^{\circ} \mathrm{C}$ miscible (Kirk-Othmer 1983, 21:382-383)

Boiling Point: $1 \mathrm{~atm} 194^{\circ} \mathrm{C}$ (Kirk-0thmer 1983, 21:382-383)

Vapor Pressure at $25^{\circ} \mathrm{C}: 0.024 \mathrm{kPa}$ (Kirk-0thmer 1983, 21:382-383)

Freezing Point: $-76^{\circ} \mathrm{C}$ (Kirk-0thmer 1983, 21:382-383)

Specific Gravity at $20^{\circ} \mathrm{C}$ : 1.021 (Kirk-0thmer 1983, 21:382-383)

(see also Dow Chemical Co. 1981) 
Methoxytriglycol

$\mathrm{HOCH}_{2} \mathrm{CH}_{2} \mathrm{OCH}_{2} \mathrm{CH}_{2} \mathrm{OHCH}_{2} \mathrm{CH}_{2} \mathrm{OCH}_{3}$

CAS No. 112-35-6

Synonyms: 2-[2-(2-methoxyethoxy)ethoxy] ethanol triethylene glycol monomethyl ether methoxy triethylene glycol

Little information located

Boiling Point: $249^{\circ} \mathrm{C}$ (Grasselli and Ritchey 1975, III: e532) 
Butoxyglycol

$\mathrm{OHCH}_{2} \mathrm{CH}_{2} \mathrm{O}\left(\mathrm{CH}_{2}\right)_{3} \mathrm{CH}_{3}$

CAS No. 111-76-2

Synonym: ethylene glycol mono-n-butyl ether same as 2-butoxyethanol (see page A.18)

Water Solubility at $25^{\circ} \mathrm{C}$ : miscible (Kirk-0thmer 1983, 21:384-385)

Boiling Point at $1 \mathrm{~atm}: 170^{\circ} \mathrm{C}$ (Kirk-0thmer 1983, 21:384-385)

Vapor Pressure at $25^{\circ} \mathrm{C}: 0.11 \mathrm{kPa}$ (Kirk-0thmer 1983, 21:384-385)

Specific Gravity at $20^{\circ} \mathrm{C}$ : 0.90075 (Kirk-0thmer 1983, 21:384-385) 
Butoxydiglycol

$\mathrm{OHCH}_{2} \mathrm{CH}_{2} \mathrm{OCH}_{2} \mathrm{CH}_{2} \mathrm{O}\left(\mathrm{CH}_{2}\right){ }_{3} \mathrm{CH}_{3}$

CAS No. $112-34-5$

Synonyms: 2-(2-butoxyethoxy) ethanol diethylene glycol monobutyl ether diethylene glycol mono-n-butyl ether

Degradation Rate: In sewage, biodegrades fast once the system acclimates to presence of the compound in some instances (results inconsistent) (in BIODEG summary database; no references cited)

Water Solubility at $25^{\circ} \mathrm{C}$ : miscible (Kirk-0thmer 1983, 21:384-385)

Boiling Point at 1 atm: $231^{\circ} \mathrm{C}$ (Kirk-0thmer 1983, 21:384-385)

Vapor Pressure at $25^{\circ} \mathrm{C}: 0.003 \mathrm{kPa}$ (Kirk-0thmer 1983, 21:384-385)

Specific Gravity at $20^{\circ} \mathrm{C}: 0.9553$ (Kirk-0thmer 1983, 21:384-385)

Freezing Point: $\quad-68^{\circ} \mathrm{C}$ (Kirk-0thmer 1983, 21:382-383) 
Ethoxytriethylene glycol

$\mathrm{C}_{2} \mathrm{H}_{5} \mathrm{OCH}_{2} \mathrm{CH}_{2} \mathrm{OCH}_{2} \mathrm{CH}_{2} \mathrm{OCH}_{2} \mathrm{CH}_{2} \mathrm{OH}$

CAS No. $112-50-5$

Synonyms: 2-[2-(2-ethoxyethoxy)ethoxy]ethanol

triethyleneglycol monoethyl ether

ethoxytriethylene glycol

Degradation Rate: $t 1 / 2>20$ days (only $22 \%$ degraded after 20 days) in seawater spiked with 3-10 mg/L glycol (Price et al. 1974)

Little information located

Boiling Point: $256^{\circ} \mathrm{C}$ (Grasselli and Ritchey 1975, IV: t1388) 
A.12 POLYNUCLEAR AROMATIC HYDROCARBONS

Benzene Rings with Common Ortho Positions

A. 66 
Phenanthrene

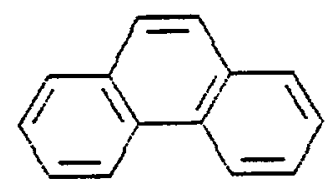

CAS No. $85-01-8$

Synonym: isometric with anthracene

$\mathrm{K}_{\mathrm{o} / \mathrm{w}}: \quad 28,840$ (Hansch and Leo 1985)

29,000 (Strenge and Peterson 1989)

Freundlich 1/N: 1.0 (Karickhoff et al. 1979), DOE Run and Hickory Hill coarse silts $3.27 \%$ and $2.78 \%$ organic carbon content, respectively, $20-$ to $50-\mu \mathrm{m}$ particle size range, $20 \mathrm{mg}$ phenanthrene $/ \mathrm{mL}, 25^{\circ} \mathrm{C}$

Water Solubility: $1.15 \mathrm{mg} / \mathrm{L}$ at $25^{\circ} \mathrm{C}$ (Schwarz 1977)

$1.3 \mathrm{mg} / \mathrm{L}$ (Strenge and Peterson 1989)

$K_{\text {oc }}: 230,000$ (Karickhoff et a1. 1979)

140,000 (Strenge and Peterson 1989)

Henry's Law Constant: $2.28 \times 10^{-5} \mathrm{~atm} \bullet \mathrm{m}^{3} / \mathrm{mol}$ (Syracuse Research Corp. 1988) calculated value

$1.6 \times 10^{-4} \mathrm{~atm} \bullet \mathrm{m}^{3} / \mathrm{mol}$ (Strenge and Peterson 1989)

$4.0 \pm 0.8 \times 10^{-5} \mathrm{~atm} \bullet \mathrm{m}^{3} / \mathrm{mol}$ (Mackay and Shiu 1981)

Melting Point: $101^{\circ} \mathrm{C}$ (Mackay and Shiu 1981)

Boiling Point: $339^{\circ} \mathrm{C}$ (Mackay and Shiu 1981)

Solid at environmental conditions

Vapor Pressure: $2.67 \times 10^{-7} \mathrm{~atm}$ (Mackay and Shiu 1981)

Adsorption: no adsorption on bentonite clay from seawater

(Meyer and Quinn 1973)

$R_{d}=50$ for sandy loam, pH 7.9, CEC $=10.10 \mathrm{meq} / 100 \mathrm{~g}, O C=0.5 \%$ (Sims et al. 1988)

$R_{d}=160$ for sandy $10 a m, p H 4.8, C E C=6.35 \mathrm{meq} / 100 \mathrm{~g}, O C=0.94 \%$ (Sims et al. 1988)

Degradation Rate: in sandy loam, $\mathrm{pH} 7.9$, partially saturated $(80 \%)$, $t 1 / 2$ = 16 days at 900 ppm loading in soil (Sims et al. 1988)

in sandy loam, $\mathrm{pH} 4.8$, partially saturated $(80 \%)$, $\mathrm{t} 1 / 2=35$ days at $900 \mathrm{ppm}$ loading in soil (Sims et al. 1988) 


\section{A.13 PHENOLS}<smiles></smiles>

\section{A. 68}




\section{Phenol}<smiles>[CH]c1ccccc1</smiles>

CAS No. 108-95-2

Synonyms: carbolic acid phenic acid phenylic acid phenyl hydroxide hydroxybenzene oxybenzene

$\mathrm{K}_{\mathrm{o} / \mathrm{w}}: 28.84$ (Hansch and Leo 1985)

29 (Gaffney et al. 1987)

Soil Sorption: No adsorption in silty clay (Greskovich 1974), adsorbed mainly by soil humus (Mozheiko and Solod 1969), no adsorption on kaolinite or montmorillonite with 1 to $100 \mathrm{mg}$ phenol/L in the influent (Luh and Baker 1970)

$$
\begin{gathered}
\text { Captina Silt Loam } \\
\qquad \text { (Scott et al. } 1983)
\end{gathered}
$$

Percent sand

Percent silt

Percent clay

CEC

$\mathrm{pH}$

Temperature

$\%$ Organic carbon

Freundlich adsorption

Freundlich $1 / \mathrm{N}$

Koc calculated
33

55

12

6

5.4

$25^{\circ} \mathrm{C}$

1.1

0.57

0.96

91
17

59

24

22

5.4

$25^{\circ} \mathrm{C}$

3.6

11.9

0.76

38.8

No phenol adsorption on goethite (Yost and Anderson 1984). Phenol sorption can vary significantly with $\mathrm{pH}$ and soil from oxide content-K of 16 (Boyd 1982). No adsorption on aquifer materials (Eholich et al. 1982) 
$K_{\text {oc }}: 14$ (Strenge and Peterson 1989).

Water Solubility: $82.8 \mathrm{~g} / \mathrm{L}$ at $25^{\circ} \mathrm{C}$ (Southworth and Keller 1986)

$93 \mathrm{~g} / \mathrm{L}$ (Strenge and Peterson 1989)

Henry's Law Constant: $3.33 \times 10^{-7} \mathrm{~atm} \bullet \mathrm{m}^{3} / \mathrm{mol}$ at $25^{\circ} \mathrm{C}$ (Gaffney et al. 1987), $4.5 \times 10^{-7} \mathrm{~atm} \bullet \mathrm{m}^{3} / \mathrm{mol}$ (Strenge and Peterson 1989)

$\mathrm{K}_{\mathrm{oC}}: 10^{3.46}$ based on Connecticut Lake sediments with 4.2 to $10.2 \% \mathrm{OC}$ (Isaacson and Frink 1984)

$10^{1.43}$ based on various soils (Dragun 1986)

Biodegradation Rate: $\mathrm{t} 1 / 2=1$ to 2.2 days in silt loams with 1.1 to $3.6 \%$ organic carbon, $\mathrm{pH} 5.4$, and an extremely low

concentration of phenol (Sims and Overcash 1983)

$\mathrm{t} 1 / 2=0.11$ to 0.15 days (Scott et al. 1982, 1983)

$\mathrm{t} 1 / 2=<1$ day in soil suspensions when present at 25-50 $\mathrm{mg} / \mathrm{L}$ (Alexander and Aleem 1961; Alexander and Lustigman 1966)

$t 1 / 2=\sim 100$ days when present in landfill leachate at concentrations between 30-90 parts per trillion (ng/L) in soils in Oklahoma (Deeley et al. 1985)

$\mathrm{t} 1 / 2=2$ to 3 days when present in soil at $100 \mathrm{mg} / \mathrm{L}$ conc. from oil refinery settling pond (Meyer et al. 1984)

$\mathrm{t} 1 / 2=\sim 5$ days in seawater when present at $3-10 \mathrm{mg} / \mathrm{L}$ added as wastewater (Price et al. 1974)

(see also Baker and Mayfield 1980; Haider et al. 1974) 


\section{A.14 PHOSPHATES}

$\mathrm{PO}_{4}$ 
Tributyl Phosphate

$\begin{aligned} & \mathrm{H}_{3} \mathrm{C}\left(\mathrm{CH}_{2}\right) \\ & \mathrm{H}_{3} \mathrm{C}\left(\mathrm{CH}_{2}\right) \\ & \mathrm{H}_{3} \mathrm{C}\left(\mathrm{CH}_{2}\right)_{3}\end{aligned}{ }_{3} \mathrm{O} \longrightarrow \mathrm{P}=0$

CAS No. $126-73-8$

$\mathrm{K}_{\mathrm{o} / \mathrm{w}}: 9,800$ (Strenge and Peterson 1989) (calculated) 10,100 (Saeger et al. 1979)

Water Solubility: $280 \mathrm{mg} / \mathrm{L}$ (Strenge and Peterson 1989; Saeger et al. 1979)

$K_{\text {oc }}: 6,000$ (Strenge and Peterson 1989) calculated

Henry's Law Constant: $0.019 \mathrm{~atm} \bullet \mathrm{m}^{3} / \mathrm{mol}$ (Strenge and Peterson 1989) calculated

Degradation Rate: $t 1 / 2 \sim 4$ to 7 days in Mississippi River water when concentration $1 \mathrm{mg} / \mathrm{L}$ (Saeger et al. 1979)

t1/2 >67 days (Strenge and Peterson 1989) 


\section{$\underline{\text { REFERENCES }}$}

Alexander, M., and M. I. H. Aleem. 1961. "Effects of Chemical Structure on Microbial Decomposition of Aromatic Herbicides." J. Agric. Food Chem. $9: 44-47$.

Alexander, M., and B. K. Lustigman. 1966. "Effect of Chemical Structure on Microbial Degradation of Substituted Benzenes." J.Agric. Food Chem. $14: 410-413$.

Apoteker, A., and D. R. Thevenot. 1983. "Experimental Simulation of Biodegradation in Rivers. Oxygen, Organic Matter and Biomass Concentration Changes." Water Res. 17:1267-1274.

Atlas, E., A. Velasco, K. Sullivan, and C. S. Giam. 1983. "A Radiotracer Study of Air-Water Exchange of Synthetic Organic Compounds." Chemosphere $12: 1251-1258$.

Bailey, G. W., J. L. White, and T. Rothberg. 1968. "Adsorption of Organic Herbicides by Montmorillonite: Role of $\mathrm{pH}$ and Chemical Character of Adsorbate." Soil Sci. Soc. Am. Proc. 32:222-234.

Baker, M. D., and C. I. Mayfield. 1980. "Microbial and Non-Biological Decomposition of Chlorophenols and Phenols in Soil." Water Air Soil Pollut. $13: 411-430$.

Boyd, S. A. 1982. "Adsorption of Substituted Phenols by Soil." Soil Science $134: 337-343$.

Briggs, G. G. 1981. "Adsorption of Pesticides by Some Australian Soils." Aust. J. Soil Res. 19:61-68.

Buckingham, J., ed. 1982. Dictionary of Organic Compounds, Vol. I-V, 5th ed. Chapman and Hall, New York.

Buttery, R. G., L. C. Ling, and D. G. Guadagni. 1969. "Food Volatiles: Volatilities of Aldehydes, Ketones and Esters in Dilute Water Solution." J. Agric. Food Chem. 17:385-389.

Calamari, D., R. Dagasso, S. Galassi, A. Provino, and M. Vighi. 1980. "Biodegradation and Toxicity of Selected Amines on Aquatic Organisms." Chemosphere 9:753-762.

Callahan, M. A., M. W. Slimak, N. W. Gabel, I. P. May, C. F. Fowler, J. R. Freed, P. Jennings, R. L. Durfee, F. C. Whitmore, and B. Maestic. 1979. Water-Related Environmental Fate of 129 Priority Pollutants, Vol. II. EPA-440/4-79-0298, U.S. Environmental Protection Agency, Washington, D.C. 
Chiou, C. T., V. H. Freed, D. W. Schmedding, and R. L. Kohnert. 1977.

"Partition Coefficient and Bioaccumulation of Selected Organic Chemicals." Environ. Sci. Technol. 11:475-478.

Cline, P. V., and D. R. Viste. 1985. "Migration and Degradation Patterns of Volatile Organic Compounds." Waste Manage. Pes. 3:351-360.

Coates, M., D. W. Connell, and S. W. Barron. 1985. "Aqueous Solubility and 0ctan-1-ol-water Partition Coefficients of Aliphatic Hydrocabons." Environ. Sci. Technol. 19:628-632.

Coca, J., and R. Diaz. 1980. "Extraction of Furfural from Aqueous Solutions with Chlorinated Hydrocarbons." J. Chem. Eng. Data 25:80-83.

Dean-Raymond, D., and M. Alexander. 1976. "Plant Uptake and Leaching of Dimethylnitrosamine." Nature 262:394-396.

Dee]ey, G. M., P. Skierkowski, and J. M. Robertson. 1985. "Biodegradation of ( $\left.{ }^{14} \mathrm{C}\right)$ Phenol in Secondary Sewage and Landfill Leachate Measured by DoubleVial Radiorespirometry." Appl. Env. Micro. 49:867-869.

Dilling, W. L. 1977. "Interphase Transfer Processes. II. Evaporation Rates of Chloromethanes, Ethanes, Ethylenes, Propanes and Propylenes from Dilute Aqueous Solutions. Comparisons with Theoretical Predictions." Environ. Sci. Technol. 11:405-409.

Dilling, W. L., N. B. Tefertiller, and G. J. Kallos. 1975. "Evaporation Rates and Reactivities of Methylene Chloride, Chloroform, 1,1,1-Trichloroethane, Trichloroethylene, Tetrachloroethylene and Other Chlorinated Compounds in Dilute Aqueous Solutions." Environ. Sci. Technol. 9:833-838.

Dojlido, J. R. 1979. Investigations of Biodegradability and Toxicity of Organic Compounds: Final Report 1975-79. EPA-600/12-79-163, U.S. Environmental Protection Agency, Cincinnati, Ohio.

Donaldson, E. C., M. E. Crocker, and F. S. Manning. 1975. Adsorption of Organic Compounds on Cottage Grove Sandstone. BERC/RI-75/4, Bartlesville Energy Research Center, Bartlesville, Oklahoma.

Dorigan, J., B. Fuller, and R. Duffy. 1976. Preliminary Scoring of Selected Organic Air Pollutants. Appendix I-Chemistry, Production and Toxicity of Chemicals A through C. EPA-450/3-77-008B, U.S. Environmental Protection Agency, Research Triangle Park, North Carolina.

Dow Chemical Company. 1981. The Gycol Ethers Handbook. Dow Chemical Company, Midland, Michigan.

Dragun, J. 1986. The Soil Chemistry of Hazardous Materials. Hazardous Material Control Research Institute (HMCRI), Silver Spring, Maryland. 
Dunlop, A. P. 1966. "Furfuran and Furan Compounds". In Kirk-0thmer Encycl. Chem. Tech., 2nd ed., vol. 10, pp. 237-251. Wiley-Interscience, New York.

Eholich, G. G., D. F. Goelitz, E. M. Godsy, and M. F. Hult. 1982. "Degradation of Phenolic Contaminants in Ground Water by Anaerobic Bacteria." Ground Water $20: 703-710$.

Fairbanks, B. C., G. A. 0'Connor, and S. E. Smith. 1985. "Fate of Di-2(Ethylhexyl) Phthalate in Three Sludge-Amended New Mexico Soils." J. Environ. Qual. 14:479-483.

Friesel, P., G. Milde, and B. Steiner. 1984. "Interactions of Halogenated Hydrocarbons with Soils." Fresenius Z. Anal. Chem. 319:160-164.

Gaffney, J. S., G. E. Streit, W. D. Spall, and J. H. Hall. 1987. "Beyond Acid Rain - Do Soluble 0xidants and Organic Toxins Interact with $\mathrm{SO}_{2}$ and $\mathrm{NO}_{\mathrm{x}}$ to Increase Ecosystem Effects?" Environ. Sci. Technol. 21:519-523.

Gerst1, Z., and U. Mingelgrin. 1984. "Sorption of Organic Substances by Soils and Sediments." Environ. Sci. Health, Part B 297-312.

Gledhill, W. E., R. G. Kaley, W. J. Adams, 0. Hicks, P. R. Michael, V. W. Saeger, and G. A. LeBlanc. 1980. "An Environmental Safety Assessment of Butyl Benzl Phthalate." Environ. Sci. Technol. 14:301-305.

Gossett, J. M. 1987. "Measurement of Henry's Law Constant for C1 and C2 Chlorinated Hydrocarbons." Environ. Sci. Technol. 21:202-206.

Grasselli, J. G., and W. M. Ritchey. 1975. Atlas of Spectral Data and Physical Constants for Organic Compounds, Vol I-VI, 2nd ed. CRC Press, Cleveland, Ohio.

Greskovich, E. J. 1974. "Equilibrium Data for Various Compounds between Water and Mud." A. I. Ch. E. J. 20:1024-1025.

Griebel, G. E., and L. D. Owens. 1972. "Nature of the Transient Activation of Soil Microorganisms by Ethanol or Acetaldehyde." Soil Biol. Biochem. 4:1-8.

Haider, K., G. Jagnow, R. Kohnen, and S. U. Lim. 1974. "Degradation of Chlorinated Benzenes. Phenols and Cyclohexane Derivatives by Benzene and Phenol Utilizing Soil Bacteria under Aerobic Conditions." Arch. Microbiol. $96: 183-200$.

Haines, J. R., and M. Alexander. 1974. "Microbial Degradation of HighMolecular Weight Alkanes." Appl. Microbiol. 28:1084-1085.

Haltori, Y., Y. Kuge, and S. Nakagorroa. 1975. "Microbial Decomposition of Phthalate Esters in Environmental Water." Mizu Shori Gyutsu 16:951-954.

Hammerton, C. 1955. "Observations on the Decay of Synthetic Anionic Detergents in Natural Water." J. App 1. Chem. 5:517-524. 
Hansch, C., and A. J. Leo. 1979. "Substituent Constants for Correlation Analysis in Chemistry and Biology." Wiley, New York.

Hansch, C., and A. J. Leo. 1981. Medchem Project. Issue No. 19. Pomona College, Claremont, California.

Hansch, C., and A. J. Leo. 1985. Medchem Project. Issue No. 26. Pomona College, Claremont, California.

Hawker, D. W., and D. W. Connel1. 1989. "A Simple Water/Octanol System for Bioconcentration Investigations." Environ. Sci. Technol. 23:961-965.

Hine, J., and P. K. Mookerjee. 1975. "The Intrinsic Hydrophilic Character of Organic Compounds. Correlations in Terms of Structural Contributions." J. Org. Chem. 40:292-298.

Horvath, A. L. 1982. Halogenated Hydrocarbons: Solubility-Miscibility with Water. Marcel Dekker, New York.

Howard, P. H., S. Banerjee, and K. H. Robrillard. 1985. "Measurement of Water Solubilities, Octanol-Water Partition Coefficients and Vapor Pressures of Commercial Phthalate Esters." Environ. Tox. Chem. 4:653-661.

Hutzler, N. J. J. C. Crittenden, J. L. Oravitz, and P. A. Schaepe. 1983. "Groundwater Transport of Chlorinated Organic Compounds." Preprints, Amer. Chem. Soc. 186th Natl. Mtg., Div. of Environ. Chem. 23:499-502.

Inman, J. C., S. D. Strachan, L. E. Sommers, and D. W. Nelson. 1984. "The Decompositon of Phthalate Esters in Soil." J. Environ. Sci. Health $\mathrm{B} 19: 245-257$.

Isaacson, P. J., and C. R. Frink. 1984. "Non-Reversible Sorption of Phenolic Compounds by Sediment Fractions: The Role of Sediment and Organic Matter." Environ. Sci. Technol. 18:43-48.

Johnson, B. T., and W. Lulves. 1975. "Biodegradation of Di-N-Butyl Phthalate and Di-2-Ethylhexyl Phthalate in Freshwater Hydrosoil." J. Fish. Res. Board Can. 32:333-339.

Johnson, B. T., M. A. Heit-Kamp, and J. R. Jones. 1984. "Environmental and Chemical Factors Influencing the Biodegration of Phthalic Acid Esters in Freshwater Sediments." Environ. Pollut. B 8:101-118.

Jungfleisch, F. M. 1988. Preliminary Evaluation of Hanford Liquid Discharges to Ground. WHC-EP-0052, Westinghouse Hanford Company, Richland, Washington.

Kaplan, D. L., and A. M. Kaplan. 1985. "Biodegradation of NNitrosodimethylamine in Organics and Soil Systems." App. Env. Microbio. $50: 1077-1086$. 
Karickhoff, S. W., D. S. Brown, and T. A. Scott. 1979. "Sorption of Hydrophobic Pollutants on Natural Sediments." Water Res. 13:241-248.

Khan, A., J. T. Hassett, W. L. Banwart, J. C. Means, and S. G Woods. 1979. "Sorption of Acetophenone by Sediments and Soils." Soil Sci. 128:297-302.

Kirk-0thmer. 1983. Kirk-0thmer Encyclopedia of Chemical Technology. WileyInterscience, New York.

Ludzack, F. J., and M. B. Ettinger. 1963. Biodegradability of Organic Chemicals Isolated from Rivers. Purdue University Engineering Bulletin Ext. Series No. 115, pp. 278-282. Purdue University, West Lafayette, Indiana.

Luh, M. D., and R. A. Baker. 1970. "Organic Sorption from Aqueous Solutions by Two Clays." In Proceedings of the 255th Industrial Waste Conference. Purdue University, Eng. Bul1., Ext. Series 25:534-542.

Mabey, W., and T. Mill. 1978. "Critical Review of Hydrolysis of Organic Compounds in Water under Environmental Conditions." J. Phys. Chem. Ref. Data $7: 383-415$.

Mackay, D., and W. Y. Shiu. 1981. "A Critical Review of Henry's Law Constants for Chemicals of Environmental Interest." J. Phys. Chem. Ref. Data. 19:1175-1199.

Mackay, D., A. Bobra, W. Y. Shiu, and S. H. Yalkowsky. 1980. "Relationships between Aqueous Solubility and Octanol-Water Partition Coefficients." Chemosphere 9:701-711.

Mackay, D., W. Y. Shiu, A. Bobra, J. Billington, E. Chau, A. Yeun, C. Ng, and F. Szeto. 1982. Volatilization of Organic Pollutants from Water. EPA-600/53-82-019, U.S. Environmental Protection Agency, Athens, Georgia.

Mallik, M., A. B. Mab, and K. Testai. 1981. "Transformation of Nitrosamines in Soil and In Vitro by Soil Microorganisms." Bull. Environ. Contain. Toxicol. $27: 115-121$.

The Merck Index 1976. 9th ed. Merck and Co., Inc., Rahway, New Jersey.

Meyer, P. A., and J. G. Quinn. 1973. "Association of Hydrocarbons and Mineral Particles in Saline Solution." Nature 244:23-24.

Meyer, J. S., M. D. Marcus, and H. L. Bergman. 1984. "Inhibitory Interactions of Aromatic Organics during Microbial Degradation." Environ. Toxicol. Chem. $3: 583-587$.

Mozheiko, A. M., and V. A. Solod. 1969. "Behavior of Monohydric Phenol in Chernozem during Irrigation with Phenol-Containing Waters." Tr. Kharkov. Selskokhoz. Inst. 81:36-45. 
Munz, C., and P. V. Roberts. 1987. "Air-Water Phase Equilibria of Volatile Organic Solutes." J. Am. Water Works Assoc. 79:62-69.

Nathwani, J. S., and C. R. Phillips. 1977. "Adsorption-Desorption of Selected Hydrocarbons on Crude 0il on Soils." Chemosphere 6:157-182.

Nazata, S., and G. Kondo. 1977. "Photoxidation of Crude 0ils." In Proceedings of the 1977 0il Spill Conference, pp. 617-620. American Petroleum Institute, Washington, D.C.

Nieneker, D. L. 1971. "Morpholine." In Kirk-0thmer Encycl. Chem. Tech. 2nd ed., vol. 13, pp. 659-670. Wiley-Interscience, New York.

Organization for Economic Cooperative Development (OECD). 1981. Guidelines for Testing of Chemicals. Organization for Economic Cooperation and Development, Berlin.

Papa, A. J., and P. D. Sherman, Jr. 1981. "Ketones." In Kirk-0thmer Encycl. Chem. Tech., 3rd ed., vol. 13, pp. 894-944. Wiley-Interscience, New York.

Park, J. H., A. Hussam, P. Conasnon, D. Fritz, and P. W. Carc. 1987. "Experimental Reexamination of Selected Partition Coefficients from Rohnschneider's Data Set." Anal. Chem. 59:1970-1976.

Perez, K. T., E. Davey, M. N. Lackie, G. Morrison, and P. Murphy. 1985. Environmental Assessment of Phthalate Ester, $\mathrm{Di}$ (2-ethylhexyl) Phthalate (DEHP) Derived from a Marine Microcosm. EPA-600/D-85-070, U.S. Environmental Protection Agency, Narrangansett, Rhode Island.

Petrasek, A. C., I. J. Kugelman, B. M. Austern, T. A. Pressley, L. A. Winslow, and R. H. Wise. 1983. "Fate of Toxic Organic Compounds in Waste Water Treatment Plants." J. Water Pollut. Control Fed. 55:1286-1296.

Price, K. S., G. T. Waggy, and R. A. Conway. 1974. "Brine Shrimp Bioassay and Seawater BOD of Petrochemicals." J. Water Pollut. Control Fed. 40:354-368.

Rathbun, R. E., D. W. Stephens, D. J. Schutty, and D. Y. Tai. 1982. "Fate of Acetone in Water." Chemosphere 11:1097-1114.

Riddick, J. A., W. B. Bunger, and T. K. Sakano. 1986. Organic Solvents: Physical Properties and Methods of Purification Techniques of Chemistry, 4th ed. Wiley-Interscience, New York.

Ringk, W., and E. T. Theimer. 1978. "Benzl Alcohol." In Kirk-0thmer Encycl. Chem. Tech., 3rd ed., vol. 3, pp. 793-802. Wiley-Interscience, New York.

Rubin, H. E., R. V. Subba-Rao, and M. Alexander. 1982. "Rates of Mineralization of Trace Concentrations of Aromatic Compounds in Lake Water and Sewage Samples." Appl. Environ. Microbiol. 43:1133-1138. 
Russe11, D. J., and B. McDuffie. 1986. "Chemodynamic Properties of Phthalate Esters: Partitioning and Soil Migration." Chemosphere 15:1003-1021.

Saeger, V. W., and E. S. Tucker. 1976. "Biodegradation of Phthalic Acid Esters in River Water and Activated Sludge." Appl. Environ. Microbiol. 31:29-34.

Saeger, V. W., 0. Hicks, R. G. Kaley, P. R. Michael, J. P. Mieure, and S. E. Tucker. 1979. "Environmental Fate of Selected Phosphate Esters." Environ. Sci. Technol. 13:840-844.

Sanborn, J. R., R. L. Metcalf, C. C. Yu, and P. Y. Lu. 1975. "Plasticizers in the Environment: The Fate of $\mathrm{Di}-\mathrm{N}$-Octyl Phthalate (DOP) in Two Model ESO Systems and Uptake and Metabolism of DOP by Aquatic Organisms." Arch. Environ. Contam. Toxicol. 3:244-255.

Sarjeant, E. P., and B. Dempsey. 1979. "Ionization Constants of Organic Acids in Aqueous Solution." IUPAC Chemical Data Series No. 23, Pergamon Press, New York.

Sax, N. I., and R. J. Lewis. 1989. Dangerous Properties of Industrial Materials, 7 th ed., Vol. II. Van Nostrand Reinhold, New York.

Schwartz, H. E., C. J. M. Amzion, H. P. M. Van Vliet, J. W. Copius-Peerebooms, and U. A. T. Brinkman. 1979. "Analys is of Phthalate Esters in Sediments from Dutch Rivers by Means of High Performance Liquid Chromatography." Int. J. Environ. Anal. Chem. 6:133-144.

Schwarz, F. P. 1977. "Determination of Temperature Dependence of Solubilities of Polycyclic Aromatic Hydrocarbons in Aqueous Solution by a Fluorescence Method." J. Chem. Eng. Data 22:273-277.

Scott, H. D., D. C. Wolf, and T. L. Lavy. 1982. "Apparent Adsorption and Microbial Degradation of Phenol by Soi1." J. Environ. Qual. 11:107-111.

Scott, H. D., D. C. Wolf, and T. L. Lavy. 1983. "Adsorption and Degradation of Phenol at Low Concentrations in Soil." J. Environ. Qual. 12:91-95.

Shanker, R., C. Ramakrishna, and P. K. Seth. 1985. "Degradation of Some Phthalic Acid Esters in Soil." Environ Pollut. Ser. A 39:1-7.

Sherman, P. D. 1978. "Aldehydes." In Kirk-0thmer Encycl. Chem. Tech., 3rd ed. vol. 1, pp. 790-798. Wiley-Interscience, New York.

Sims, R. C., and M. R. Overcash. 1983. "Fate of Polynuclear Aromatic Hydrocarbons in Soil-Plant Systems." Residue Reviews 88:1-68.

Sims, R. C., W. J. Doucette, J. E. McLean, W. J. Grenney, and R. Ryan Dupont. 1988. Treatment Potential for 56 EPA Listed Hazardous Chemicals in Soil. EPA/600/6-88-001. U. S. Environmental Protection Agency, Robert S. Kerr Environmental Research Laboratory, Ada, Oklahoma. 
Smith, T. E., and R. F. Bonner. 1951. "Acetaldelyde, Propionaldehyde, and nButyraldehyde: Some Physical Properties." Ind. and Eng. Chem. 43:1169-1173.

Snider, J. R., and G. A. Dawson. 1985. "Tropospheric Light Alcohols, Carbonyls, and Acetonitrile Concentrations in the Southwestern United States and Henry's Law Data." J. Geophys. Res., D. Atmos. 90:3797-3805.

Southworth, G. R., and J. L. Keller. 1986. "Hydrophobic Sorption of Polar Organics by Low Organic Carbon Soils." Water Air Soil Pollut. 28:239-248.

Strenge, D. L., and S. R. Peterson. 1989. Chemical Data Bases for Multimedia Environmental Pol lutant Assessment System (MEPAS): Version 1. PNL-7145, Pacific Northwest Laboratory, Richland, Washington.

Stu1, M. S., J. B. Uytterhoeven, J. Debock and P. L. Huyskens. 1979. "The Adsorption of $n$-aliphatic Alcohols from Dilute Aqueous Solutions on $\mathrm{RH}_{3}$-Montmorillonites. II. Interlamellar Association of the Adsorbate." Clays Clay Miner. 27:377-386.

Subboa-Rao, R. V., H. E. Rubin, and M. Alexander. 1982. "Kinetics and Extent of Mineralization of Organic Chemicals at Trace Levels in Freshwater and Sewage." Appl. Environ. Microbiol. 43:1139-1150.

Sugatt, R. H., D. P. 0. Grady, S. Benerjee, P. H. Howard, and W. E. Gledhi11. 1984. "Shake Flask Biodegradation of 14 Commercial Phthalate Esters." Appl. Environ. Microbiol. 47:601-606.

Sullivan, K. F., E. L. Atlas, and C. S. Giam. 1981. "Loss of Phthalic Acid Esters and Polychlorinated Biphenyls from Seawater Samples during Storage." Anal. Chem. 53:1718-1719.

Sullivan, K. F., E. L. Atlas, and C. S. Giam. 1982. "Adsorption of Phthalic Acid Esters from Seawater." Environ. Sci. Technol. 16:428-432.

Sutton, C., and J. A. Calder. 1974. "Solubility of Higher-Molecular-Weightn-Paraffins in Distilled Water and Seawater." Environ. Sci. Technol. 8:654-657.

Syracuse Research Corp. 1988. SRC-Calculated values that are present in the CHEMFATE database, Syracuse University, Syracuse, New York.

Taft, R. W., M. H. Abraham, R. M. Dougherty, and M. J. Kamlet. 1985. "The Molecular Properties Governing Solubilities of Nonelectrolytes in Water." Nature 313:384-386.

Tate, R. L. III, and M. Alexander. 1976. "Resistance of Nitrosamines to Microbial Attack." J. Environ. Qual. 5:131-133.

Tewari, Y. B., M. M. Miller, and S. P. Wasik. 1982. "Calculation of Aqueous Solubility of Organic Compounds." J. Res. NBS 87:155-158. 
U.S. Environmental Protection Agency (EPA). 1981. Treatability Manual I. Treatability Data. EPA-600/2-82-001A, U.S. Environmental Protection Agency, Washington, D.C.

Verschueren, K. 1983. Handbook of Environmental Data on Organic Chemicals, 2nd ed. Van Nostrand Reinhold, New York.

Wakeham, S. G., A. C. Davis, and J. L. Karas. 1983. "Mesocosm Experiments to Determine the Fate and Persistence of Volatile Organic Compounds in Coastal Seawater." Environ. Sci. Technol. 17:611-617.

Wakeham, S. G., E. A. Canuel, and P. H. Doering. 1986. "Behavior of Aliphatic Hydrocarbons in Coastal Seawater: Mesocosm Experiments with $\left({ }^{14} \mathrm{C}\right)$ 0ctadecane and $\left({ }^{14} \mathrm{C}\right)$ Decane." Environ. Sci. Technol. 20:574-580

Walker, W. W., C. R. Cripe, P. H. Pritchard and A. W. Bourquin. 1984. "Dibutylphthalate Degradation in Estuarine and Freshwater Sites." Chemosphere 9:231-249.

Westinghouse Hanford. 1989. Waste Stream Characterization Report. WHC-EP-0287, Westinghouse Hanford Company, Richland, Washington.

Wilson, J. T., C. G. Enfield, W. J. Dunlap, R. L. Cosby, D. A. Foster, and L. B. Baskin. 1981. "Transport and Fate of Selected Organic Pollutants in a Sandy Soil." J. Environ. Qual. 10:501-506.

Wolfe, N. L., L. A. Burns, and W. C. Steen. 1980. "Use of Linear Free Energy Relationships on an Evaluative Model to Assess the Fate and Transport of Phthalate Esters in the Aquatic Environment." Chemosphere 9:403-408.

Yost, E. C., and M. A. Anderson. 1984. "Absence of Phenol Adsorption on Goethite." Environ. Sci. Technol. 18:101-106.

Zoeteman, B. C. J., K. Hermsen, J. B. H. J. Linders, C. F. H. Morra, and W. Slooff. 1980. "Persistent Organic Pollutants in River Water and Groundwater of The Netherlands." Chemosphere 9:231-249.

Zoeteman, B. C. J., E. Degree1, and F. J. J. Brinkman. 1981. "Persistence of Organic Contaminants in Ground Water, Lessons from Soil Pollution Incidents in The Netherlands." Sci. Total Environ. 21:187-202. 


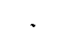


APPENDIX B

EXAMPLES OF HANFORD SEDIMENT COLUMN LEAKAGE OF ORGANIC COMPOUNDS AND RADIONUCLIDES 



\section{APPENDIX B}

\section{EXAMPLES OF SEDIMENT COLUMN LEAKAGE OF ORGANIC COMPOUNDS AND RADIONUCLIDES AT THE HANFORD SITE}

This appendix lists examples of probable sediment column leakage of organic compounds and radionuclides. Only positive values (greater than the analytical detection limit) for organics and radionuclides in the groundwater were used as indicators of sediment column leakage because inorganics are present in the groundwater naturally and may even be leached from the soil column by the wastewater. Inorganic analytical results for the groundwater samples were not, therefore, used in the following examples.

The distribution of major contaminants on the Hanford Site (Figure B.1) is given in Figure B.2. A single waste stream has not been identified with each disposal facility because many facilities have received several wastes or been taken in and out of operation one or more times. Several facilities have, however, been associated with a single wastewater. For example, the $216-W-L C W$ crib has always received laundry waste waters from the 2724-W and 2723-W buildings.

The various specific disposal facilities are associated with the major unconfined aquifer contaminants as shown in Figure B.2. Available data are best used as indicative of the type of radionuclides leaking through the sediment column. Cesium-137 and strontium-90 leakage is generally low; groundwater contains low activities in the tenths of a picocurie per liter to less than $5 \mathrm{pCi} / \mathrm{L}$. Tritium, on the other hand, is often present in quantities as high as millions of picocuries per liter. Cobalt-60, ruthenium-106, and antimony-125 are often present at levels of 10 to $800 \mathrm{pCi} / \mathrm{L}$. These leakage levels generally agree well with the sediment column distribution coefficients expected for these radionuclides, as discussed in Section 5. In this appendix, monitoring well locations relative to each disposal unit are given first, followed by tables of the wastewater components analytically identified in the groundwater. Organic components were generally low in concentration, but methylene chloride and TOX (total organic halogens) values can 
occasionally be found into the $10,000-\mathrm{ppb}$ range. The period during which these samples were taken was March 1985 to March 1989.

Our presumption is that the detection of organics and radionuclides in the monitoring wells is an indication that liquid disposal in the designated facility (or a neighboring one) has lead to the migration of the designated constituents to the upper unconfined aquifer. 


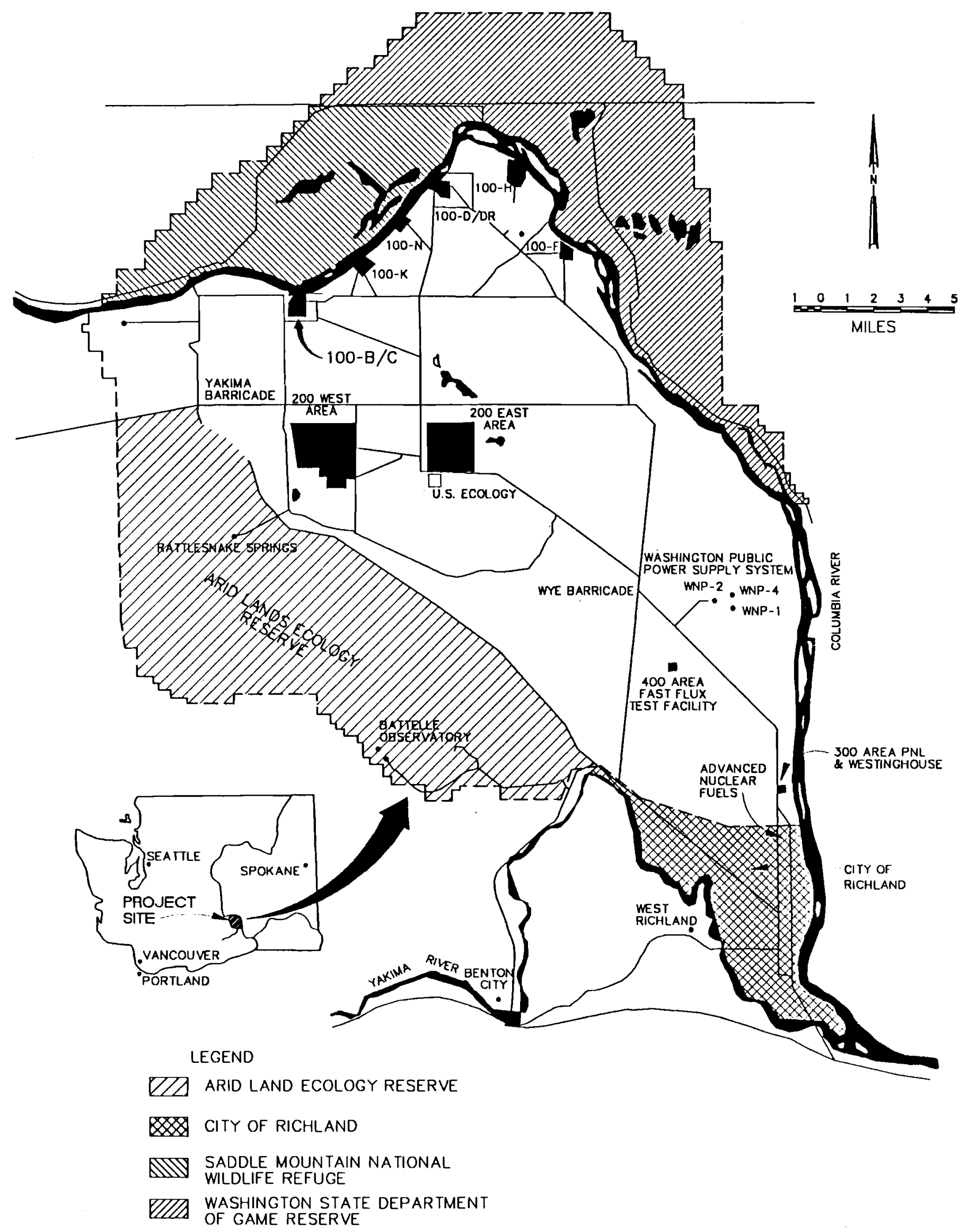

FIGURE B-1. Hanford Site 


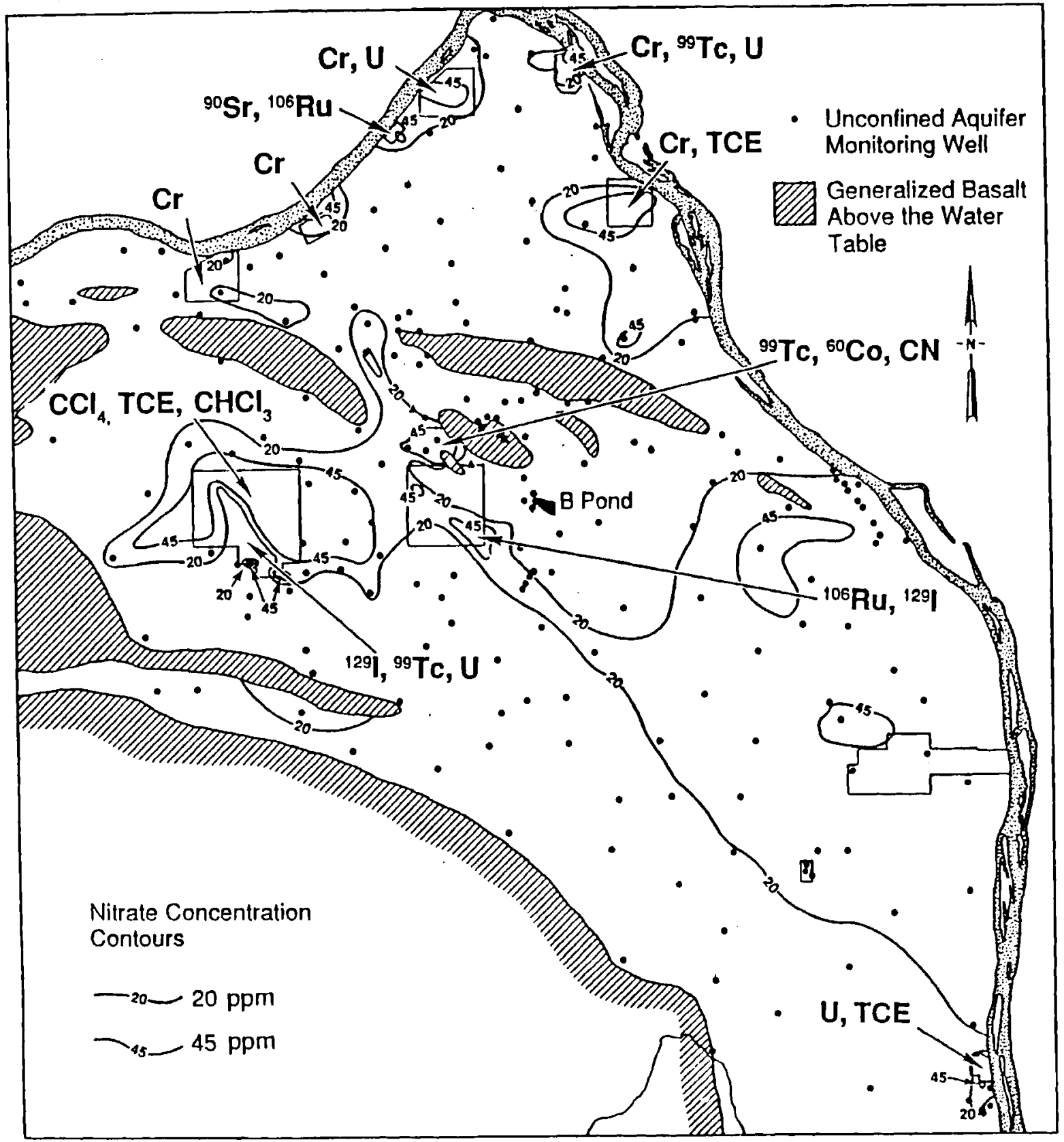

$\mathrm{CCl}_{4}=$ carbon tetrachloride

TCE $=1,1,1$-trichloroethane; tetrachloroethylene

$\mathrm{CHCl}_{3}=$ chloroform

$\mathrm{CN}$ = cyanide

FIGURE B-2. Distribution of Major Contaminants in the Unconfined Aquifer at the Hanford Site 


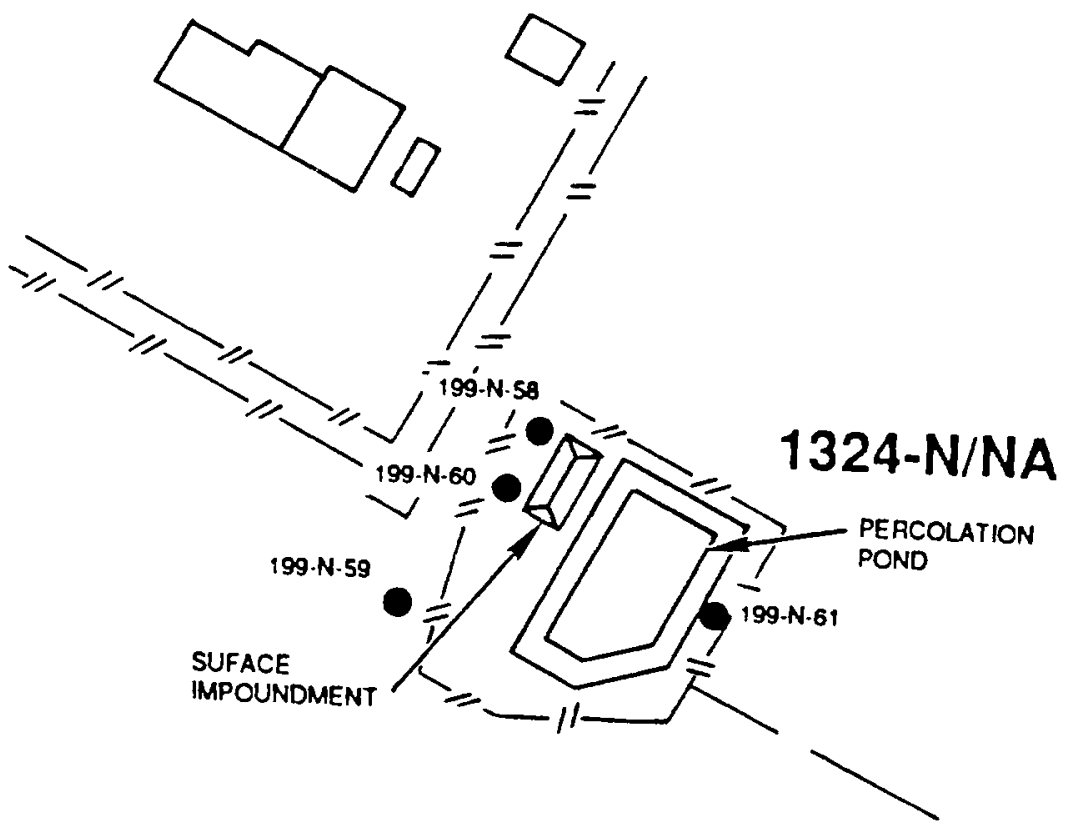

FIGURE B.3. Monitoring Well Locations at 1324-N/NA Pond

TABLE B.1. Sediment Column Leakage of Waste Components Disposed to $1324-\mathrm{N} / \mathrm{NA}$ Pond $(120-\mathrm{N}-1)$

\begin{tabular}{|c|c|}
\hline $\begin{array}{c}\text { Monitoring } \\
\text { Well } \\
\end{array}$ & Organics Identified in Groundwater \\
\hline $199-N-58$ & Methylene chloride, TOX \\
\hline $199-N-59$ & Chloroform, TOX \\
\hline $199-N-60$ & Chloroform, TOX \\
\hline \multirow[t]{2}{*}{$199-N-61$} & Chloroform, Bis(2-ethylhexyl)phthalate, TOH \\
\hline & Radionuclides Identified in Groundwater \\
\hline $199-N-58$ & None \\
\hline $199-N-59$ & None \\
\hline $199-N-60$ & None \\
\hline $199-N-61$ & None \\
\hline
\end{tabular}

B. 5 


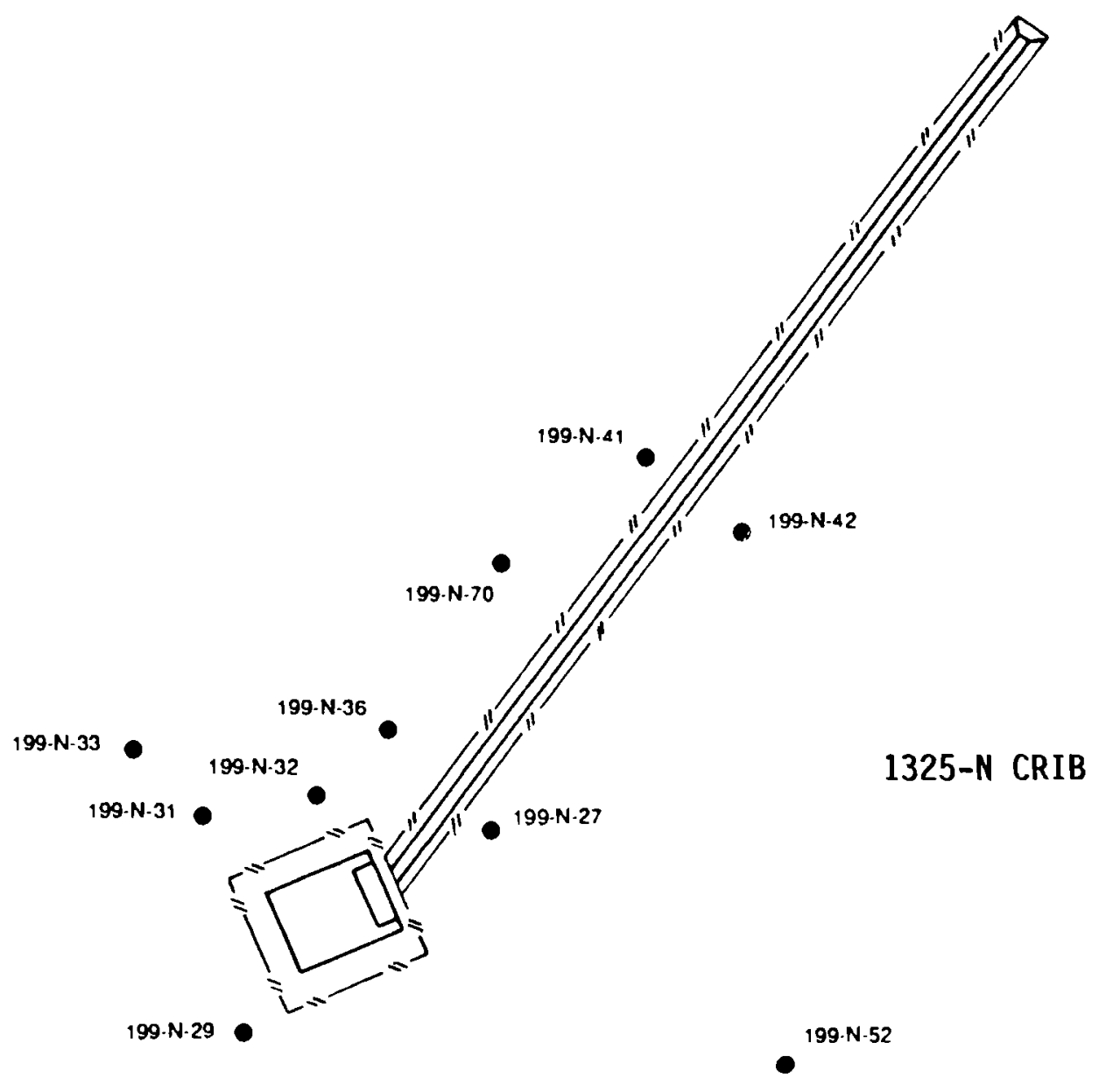

FIGURE B.4. Monitoring Well Locations around 1325-N Crib

B. 6 
TABLE B.2. Sediment Column Leakage of Waste Components Disposed to $1325-\mathrm{N}$ Crib $(120-\mathrm{N}-2)$

\begin{tabular}{|c|c|}
\hline $\begin{array}{c}\text { Monitoring } \\
\text { Well }\end{array}$ & Organics Identified in Groundwater \\
\hline $199-N-27$ & Acetone, chloroform, TOX \\
\hline $199-N-29$ & Chloroform, TOX \\
\hline $199-N-31$ & Chloroform, TOX \\
\hline $199-N-32$ & Chloroform, TOX \\
\hline $199-N-33$ & Chloroform, bis(2-ethylhexyl)phthalate \\
\hline $199-N-36$ & Acetone, chloroform \\
\hline $199-N-41$ & Methylene chloride, TOX \\
\hline $199-N-42$ & Acetone, methylene chloride, TOX \\
\hline $199-N-52$ & TOX \\
\hline \multirow[t]{2}{*}{$199-N-70$} & TOX \\
\hline & Radionuclides Identified in Groundwater \\
\hline $199-N-27$ & Cobalt-60, antimony-125, technetium-99, tritium \\
\hline $199-N-29$ & $\begin{array}{l}\text { Antimony-125, cobalt-60, iodine-129, ruthenium-106, } \\
\text { strontium-90, tritium, technetium- } 99\end{array}$ \\
\hline $199-N-31$ & $\begin{array}{l}\text { Antimony-125, cobalt-60, ruthenium-106, strontium- } 90 \text {, } \\
\text { technetium-99, tritium }\end{array}$ \\
\hline $199-N-32$ & $\begin{array}{l}\text { Cobalt-60, antimony-125, ruthenium-106, strontium-90, } \\
\text { technetium-99, tritium }\end{array}$ \\
\hline $199-N-33$ & $\begin{array}{l}\text { Antimony-125, cobalt-60, iodine-129, ruthenium-106, } \\
\text { strontium-90, tritium }\end{array}$ \\
\hline $199-N-36$ & $\begin{array}{l}\text { Antimony-125, cobalt-60, ruthenium-106, strontium-90, } \\
\text { tritium }\end{array}$ \\
\hline $199-N-41$ & Cobalt-60, tritium \\
\hline $199-N-42$ & Cobalt-60, tritium \\
\hline $199-N-52$ & Cobalt-60, technetium-99, tritium \\
\hline $199-N-70$ & Cobalt-60, ruthenium-106, tritium \\
\hline
\end{tabular}

\section{B.7}




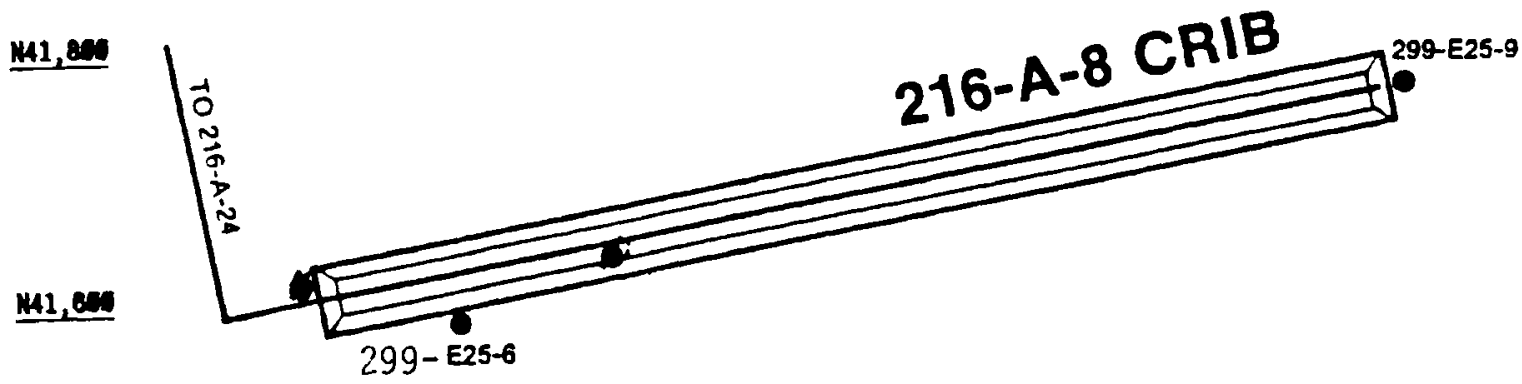

$M 1,45$

8
8
9

8
9

8
8

3
8

8
8

FIGURE B.5. Monitoring Well Locations at 216-A-8 Crib

TABLE B.3. Sediment Column Leakage of Waste Components Disposed to $216-A-8$ Crib $(216-A-8)$

Monitoring

Wel1

299-E25-6

Organics Identified in Groundwater

$299-E 25-9$

None

None

299-E25-6

Radionuclides Identified in Groundwater

$299-E 25-9$

Ruthenium-106, tritium

Ruthenium-106, tritium 


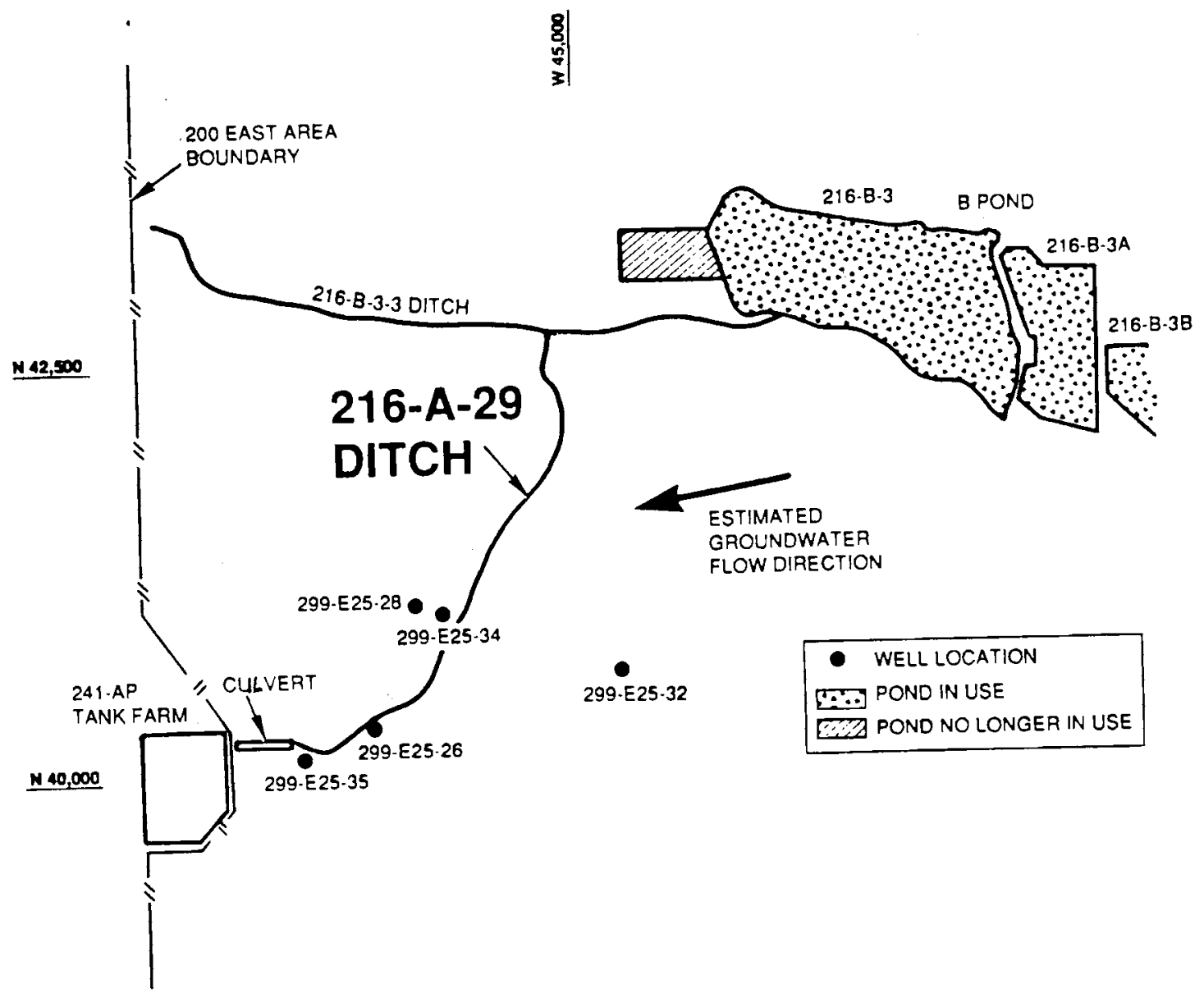

FIGURE B.6. Monitoring We11 Locations Around the 216-A-29 Ditch 
TABLE B.4. Sediment Column Leakage of Waste Components Disposed to 216-A-29 Ditch (216-A-29)/216-B-3 Pond

Monitoring Well

299-E25-26

$299-E 25-28$

299-E25-32

299-E25-34

299-E25-35

299-E25-26

299-E25-28

299-E25-32

299-E25-34

299-E25-35
Organics Identified in Groundwater
Radionuclides Identified in Groundwater

Cobalt-60, cesium-137, ruthenium-106, tritium

Cesium-137, cobalt-60, ruthenium-106, technetium-99, tritium

Technetium-99, tritium

Tritium

Tritium 

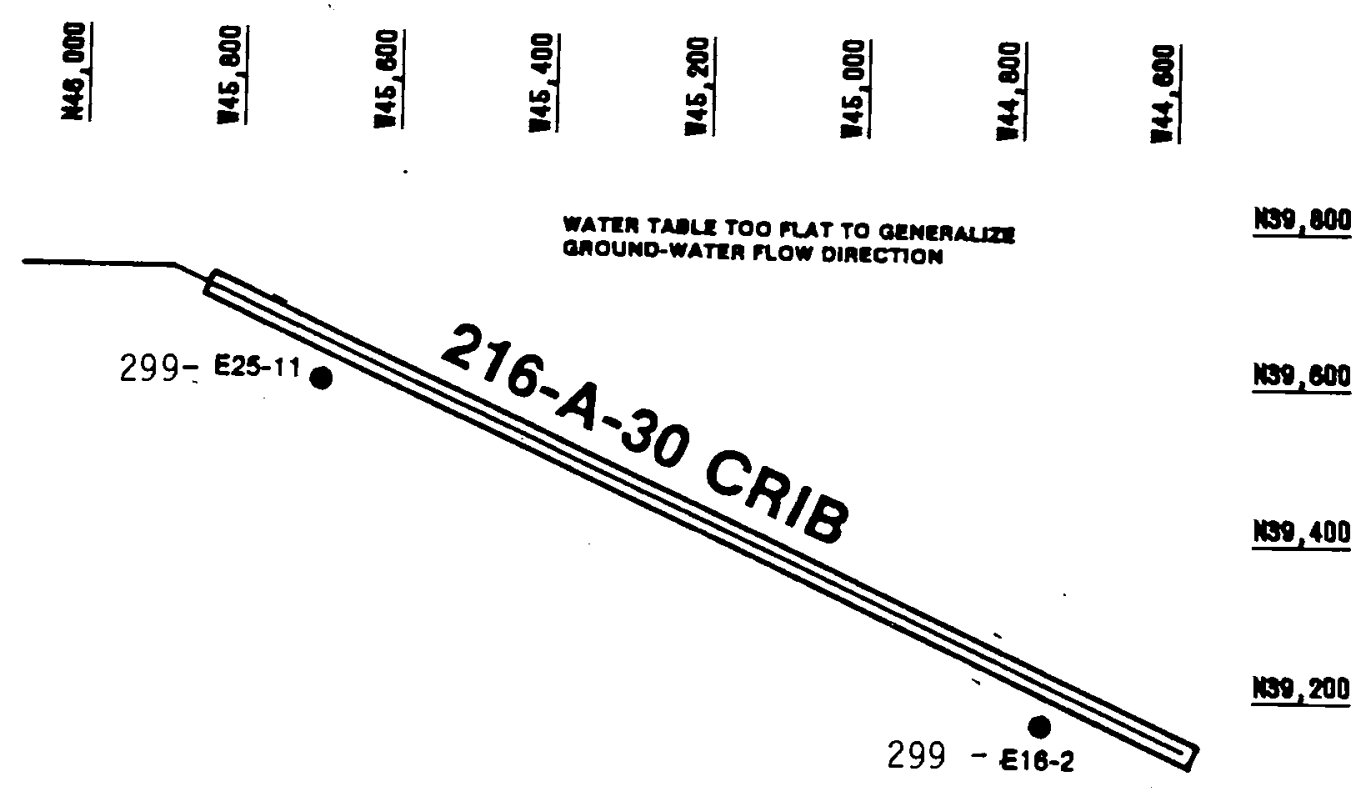

$\underline{159,000}$

FIGURE B.7. Monitoring Well Locations at 216-A-30 Crib

TABLE B.5. Sediment Column Leakage of Waste Components Disposed to 216-A-30 Crib (216-A-30)

Monitoring

Well Organics Identified in Groundwater

299-E16-2

$299-E 25-11$

None

None

Radionuclides Identified in Groundwater

$299-E 16-2$

Cesium-137, cobalt-60, ruthenium-106, strontium-90, tritium

299-E25-11

Cesium-137, cobalt-60, ruthenium-106, strontium-90, tritium 


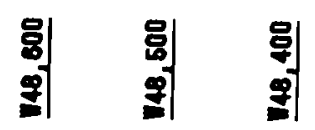

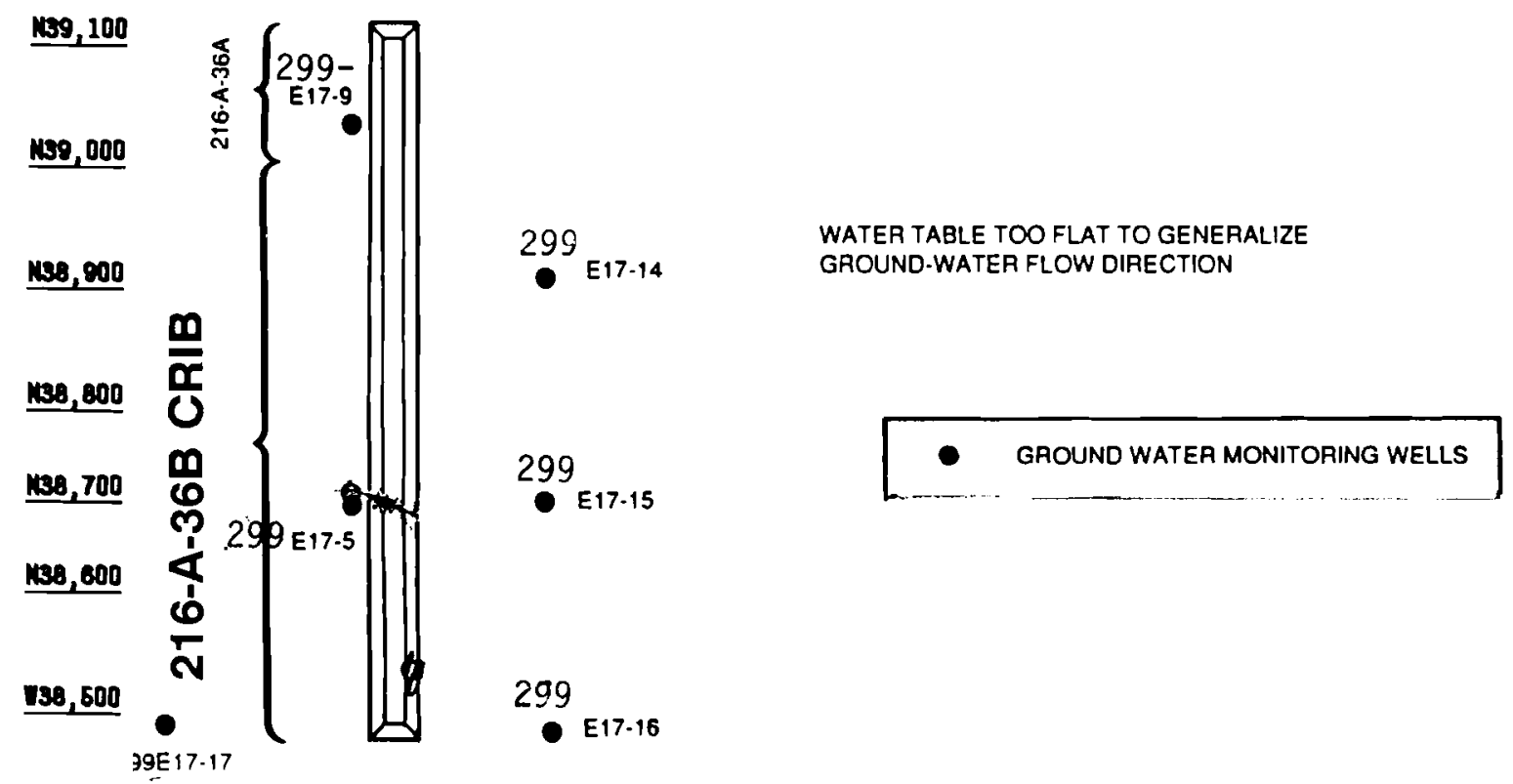

FIGURE B.8. Monitoring Well Locations at 216-A-36B Crib 
TABLE B.6. Sediment Column Leakage of Waste Components Disposed to 216-A-36B Crib

Monitoring

Well

299-E17-5

299-E17-9

299-E17-14

299-E17-15

299-E17-16

299-E17-17

299-E17-5

299-E17-9

299-E17-14

299-E17-15

299-E17-16

299-E17-17

\section{Organics Identified in Groundwater}

TOX

2-propanol, acetone

TOX

Bis(2-ethylhexyl)phthalate, methylene chloride, TOX Acetone, methylene chloride, TOX

Trichlorofluoromethane

Radionuclides Identified in Groundwater

Carbon-14, cesium-137, cobalt-60, iodine-129, ruthenium-106, strontium-90, tritium

Cesium-134, cobalt-60, iodine-129, ruthenium-106, strontium-90, technetium-99, tritium

Cobalt-60, iodine-129, ruthenium-106, strontium-90, technetium-99, tritium

Cobalt-60, ruthenium-106, strontium-90, technetium-99, tritium

Cobalt-60, iodine-129, technetium-99, tritium

Cobalt-60, iodine-129, ruthenium-106, technetium-99, tritium 


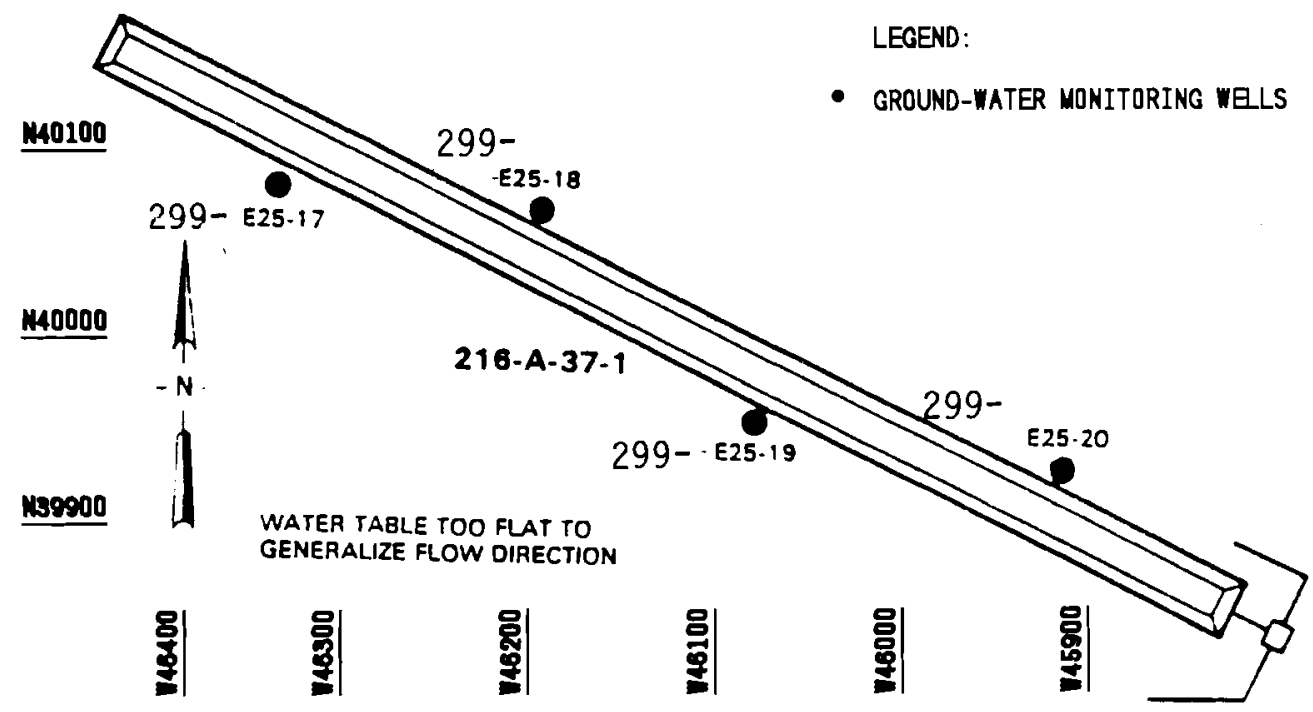

FIGURE B.9. Monitoring Well Locations at 216-A-37-1 Crib

TABLE B.7. Sediment Column Leakage of Waste Components Disposed to 216-A-37-A Crib (216-A-37-1)

\begin{tabular}{ll}
$\begin{array}{c}\text { Monitoring } \\
\text { Well }\end{array}$ & \multicolumn{1}{c}{ Organics Identified in Groundwater } \\
$299-E 25-17$ & None \\
$299-E 25-18$ & Acetone, TOX \\
$299-E 25-19$ & Methyl ethyl ketone, TOX \\
$299-E 25-20$ & None \\
$299-E 25-17$ & Radionuclides Identified in Groundwater \\
$299-E 25-18$ & $\begin{array}{l}\text { Cesium-137, cobalt-60, strontium-90, tritium } \\
\text { Cesium-137, cobalt-60, ruthenium-106, strontium-90, } \\
\text { technetium-99, tritium } \\
\text { Cesium-137, cobalt-60, ruthenium-106, strontium-90, } \\
\text { tritium } \\
\text { Cesium-137, cobalt-60, ruthenium-106, technetium-99, } \\
\text { tritium }\end{array}$
\end{tabular}



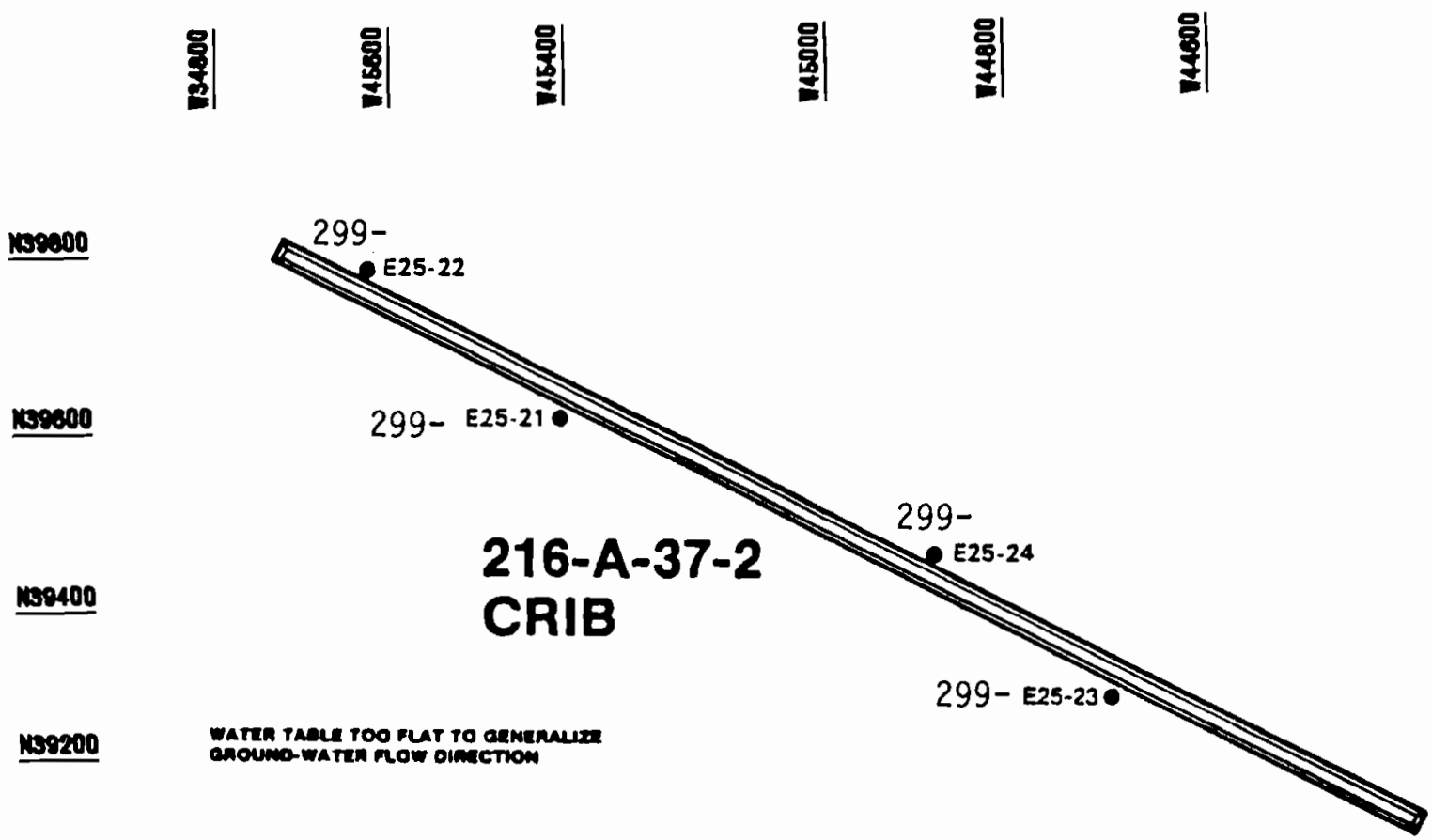

FIGURE B.10. Monitoring Well Locations at 216-A-37-2 Crib

TABLE B.8. Sediment Column Leakage of Waste Components Disposed to $216-A-37-2$ Crib $(216-A-37-2)$

Monitoring Well

299-E25-21

299-E25-22

299-E25-23

$299-E 25-24$

299-E25-21

$299-E 25-22$

$299-E 25-23$

$299-E 25-24$

\section{Organics Identified in Groundwater}

None

None

Styrene

None

Radionuclides Identified in Groundwater

Cesium-137, cobalt-60, ruthenium-106, strontium-90, tritium

Cesium-137, cobalt-60, ruthenium-106, technetium-99, tritium

Cesium-137, cobalt-60, ruthenium-106, strontium-90, tritium

Cesium-137, cobalt-60, ruthenium-106, strontium-90, tritium 


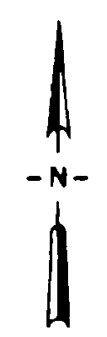

138400

$\underline{\text { M39200 }}$

$$
299-\mathbf{E} 17-12
$$

\section{LEGEND}

GROUND-WATER MONITORING WELLS

$1 \mathbf{1 0 1 0 0}$

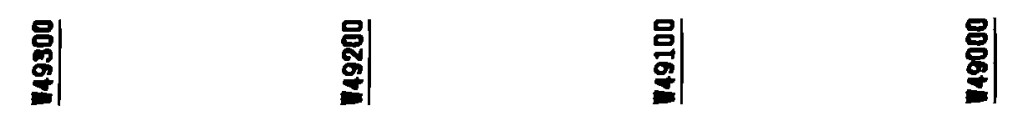

FIGURE B.11. Monitoring We11 Locations at 216-A-45 Crib

TABLE B.9. Sediment Column Leakage of Waste Components Disposed to $216-A-45$ Crib (216-A-45)

Monitoring Well

299-E17-12

299-E17-13

$299-\mathrm{E} 17-12$

299-E17-13

\section{Organics Identified in Groundwater}

None

None

Radionuclides Identified in Groundwater

Cesium-137, cobalt-60, iodine-129, plutonium-239/40, ruthenium-106, technetium-99, tritium

Cesium-137, cobalt-60, plutonium-239/40, ruthenium-106, strontium-90, technetium-99, tritium

B. 16 


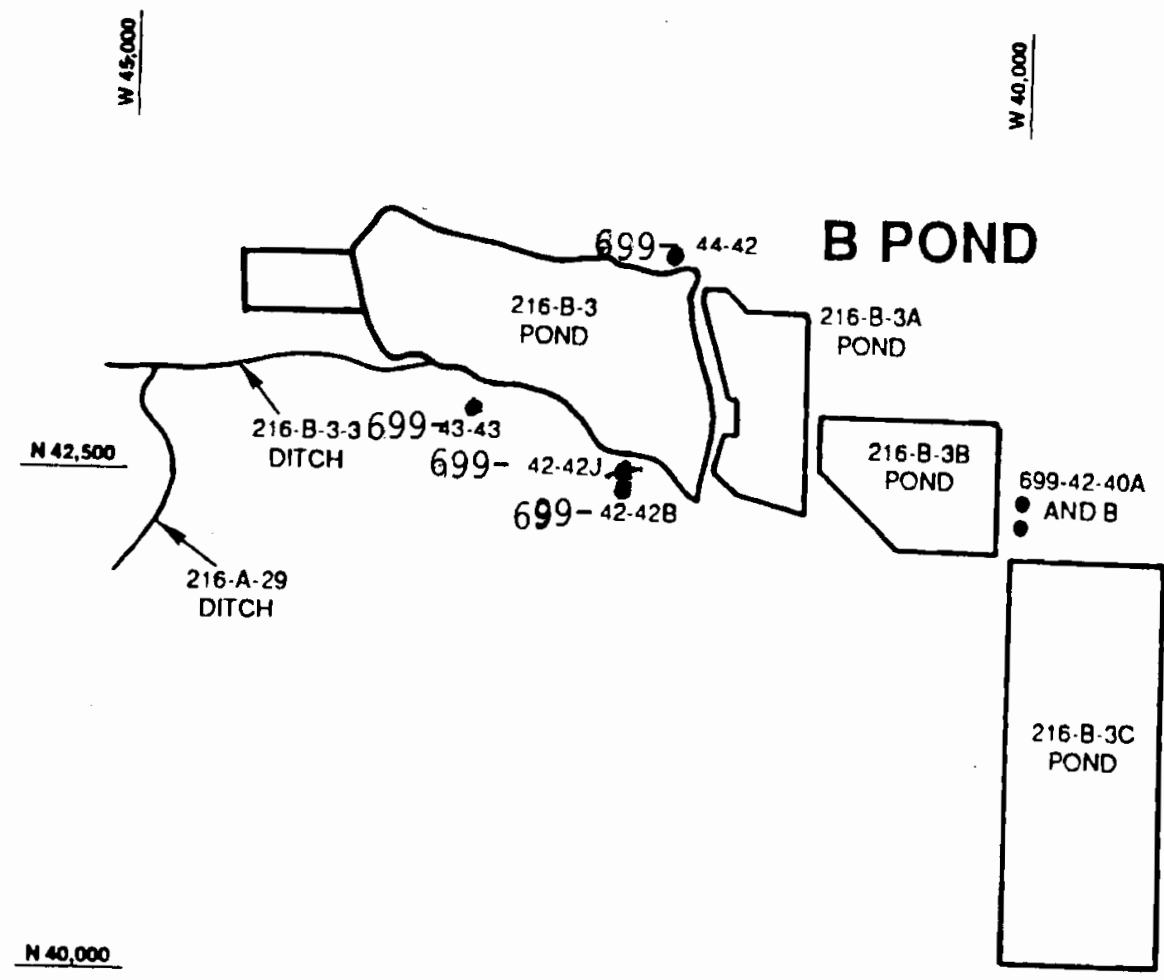

FIGURE B.12. Monitoring We11 Locations at B Pond 
TABLE B.10. Sediment Column Leakage of Waste Components Disposed to B Pond System

\begin{tabular}{ll}
$\begin{array}{c}\text { Monitoring } \\
\text { Wel1 }\end{array}$ & \multicolumn{1}{c}{ Organics Identified in Groundwater } \\
$\begin{array}{c}699-42-40 A \\
699-42-40 B\end{array}$ & TOX \\
$699-42-42 B$ & TOX \\
$699-42-42 J$ & Acetone \\
$699-43-43$ & TOX \\
$699-44-42$ & TOX \\
& \\
& Cesium-137, cobalt-60, ruthenium-106, tritium \\
$699-42-40 A$ & Cesium-137, cobalt-60, ruthenium-106, strontium-90, \\
$699-42-40 B$ & Tritium \\
$699-42-42 B$ & Tritium \\
$699-42-42 J$ & Tritium \\
$699-43-43$ & Tritium \\
$699-44-42$ & Tritium
\end{tabular}




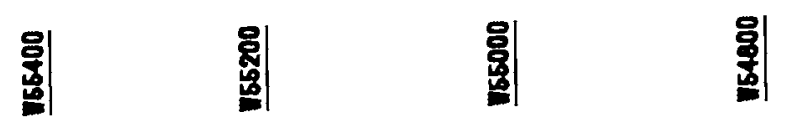

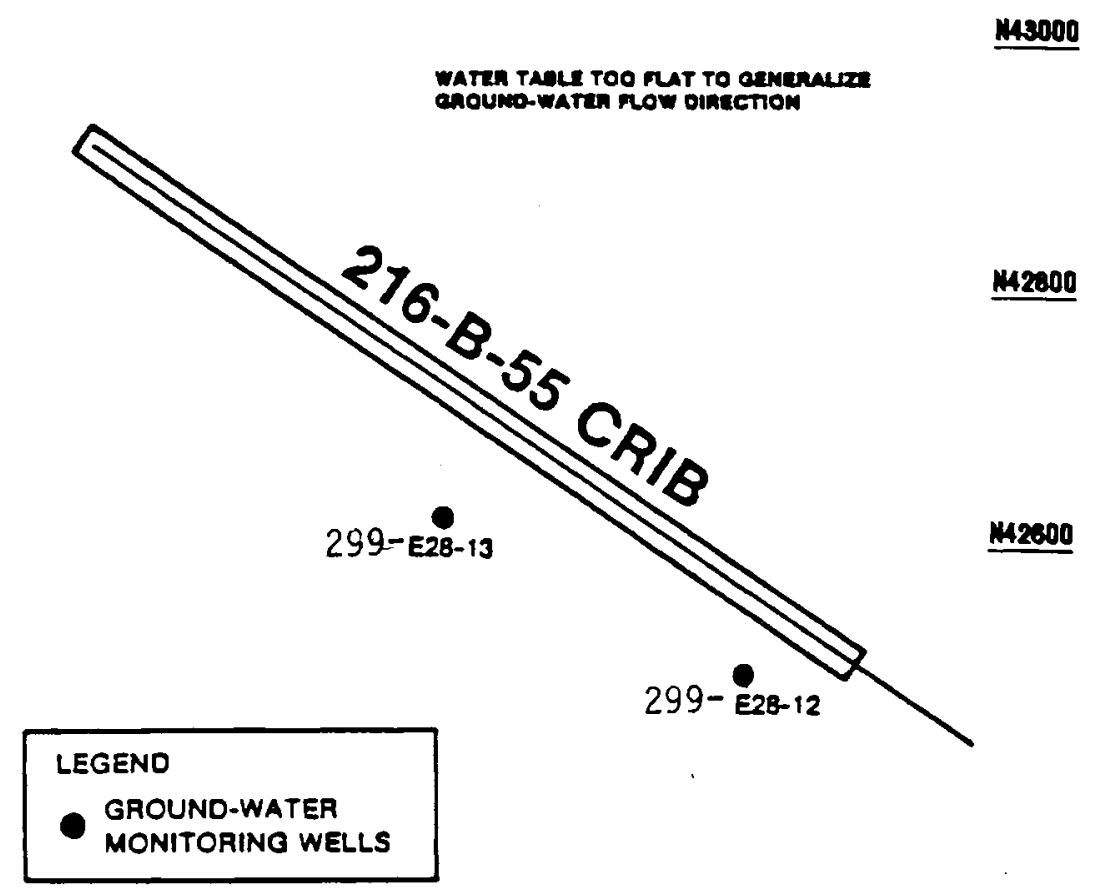

FIGURE B.13. Monitoring We11 Locations At 216-B-55 Crib

TABLE B.11. Sediment Column Leakage of Waste Components Disposed to 216-B-55 Crib (216-B-55)

$$
\begin{gathered}
\begin{array}{c}
\text { Monitoring } \\
\text { Well }
\end{array} \\
\frac{299-E 28-12}{299-E 28-13}
\end{gathered}
$$

299-E28-12

299-E28-13

\section{Organics Identified in Groundwater}

None

TOX

Radionuclides Identified in Groundwater

Cesium-137, cobalt-60, ruthenium-106, tritium Cesium-137, cobalt-60, ruthenium-106, tritium 


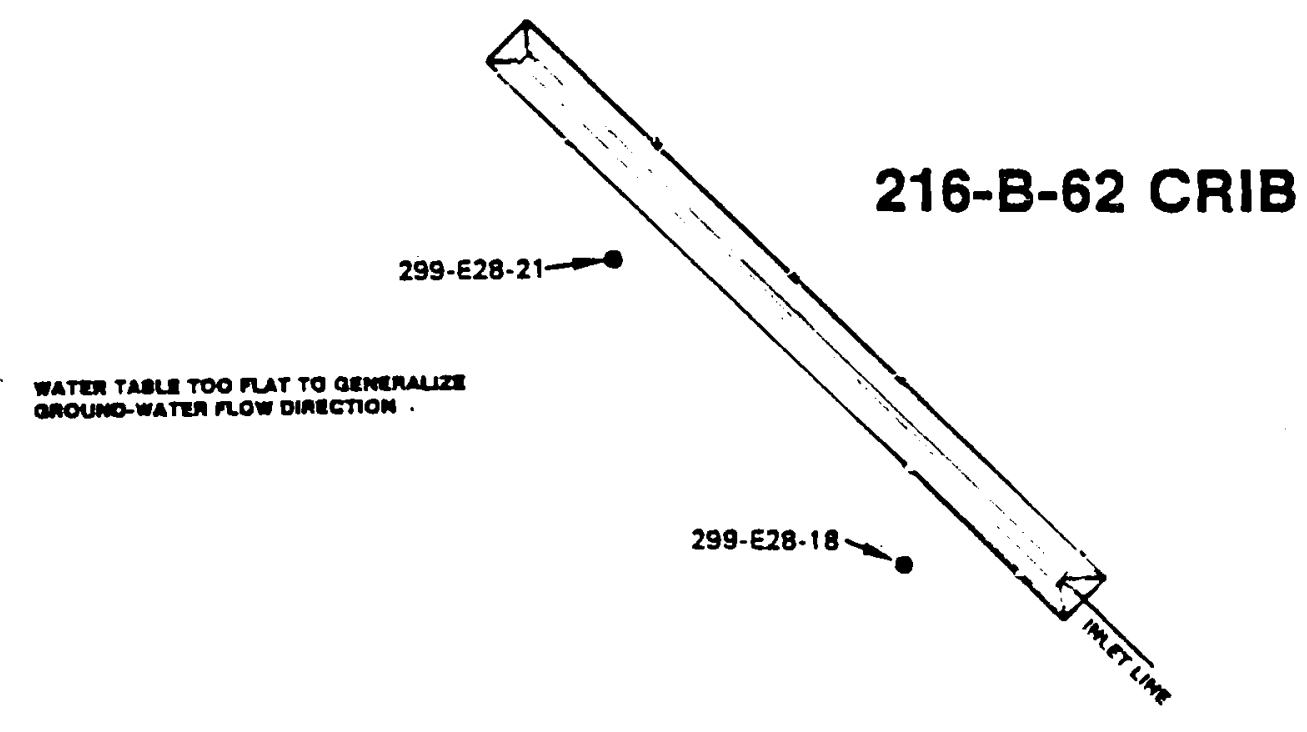

N49000

$\underline{M 3800}$

$\underline{M 3700}$

$\underline{M 3600}$

$\underline{M 3500}$

GROUND-WATER MONITORING WEUS

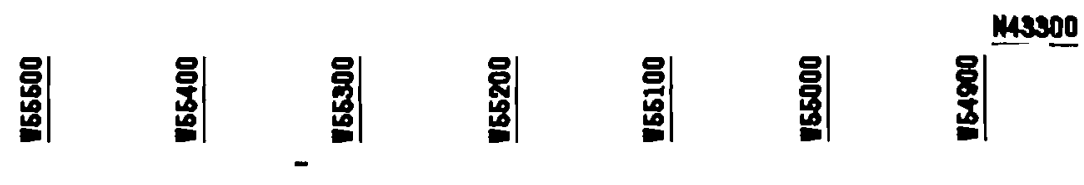

FIGURE B.14. Monitoring Well Locations at 216-B-62 Crib

TABLE B.12. Sediment Column Leakage of Waste Components Disposed to 216-B-62 Crib (216-B-62)

Monitoring Well

299-E28-18

299-E28-21

$299-E 28-18$

299-E28-21

\section{Organics Identified in Groundwater}

None

TOX

Radionuclides Identified in Groundwater

Cesium-137, cobalt-60, ruthenium-106, strontium-90, tritium

Cesium-137, cobalt-60, ruthenium-106, strontium-90, tritium 
mangen

8

욤

8

8

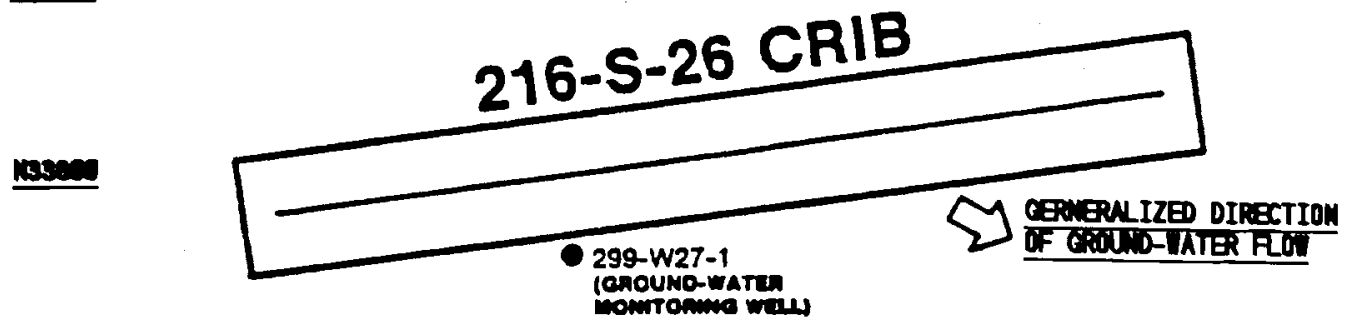

1093700

FIGURE B.15. Monitoring Well at 216-S-26 Crib

TABLE B.13. Sediment Column Leakage of Waste Components Disposed to $216-\mathrm{S}-26 \mathrm{Crib}(216-\mathrm{S}-26)$

Monitoring Well

$299-W 27-1$

Organics Identified in Groundwater

Chloroform

Radionuclides Identified in Groundwater

299-W27-1

Cesium-137, cobalt-60, ruthenium-106, strontium-90, tritium 


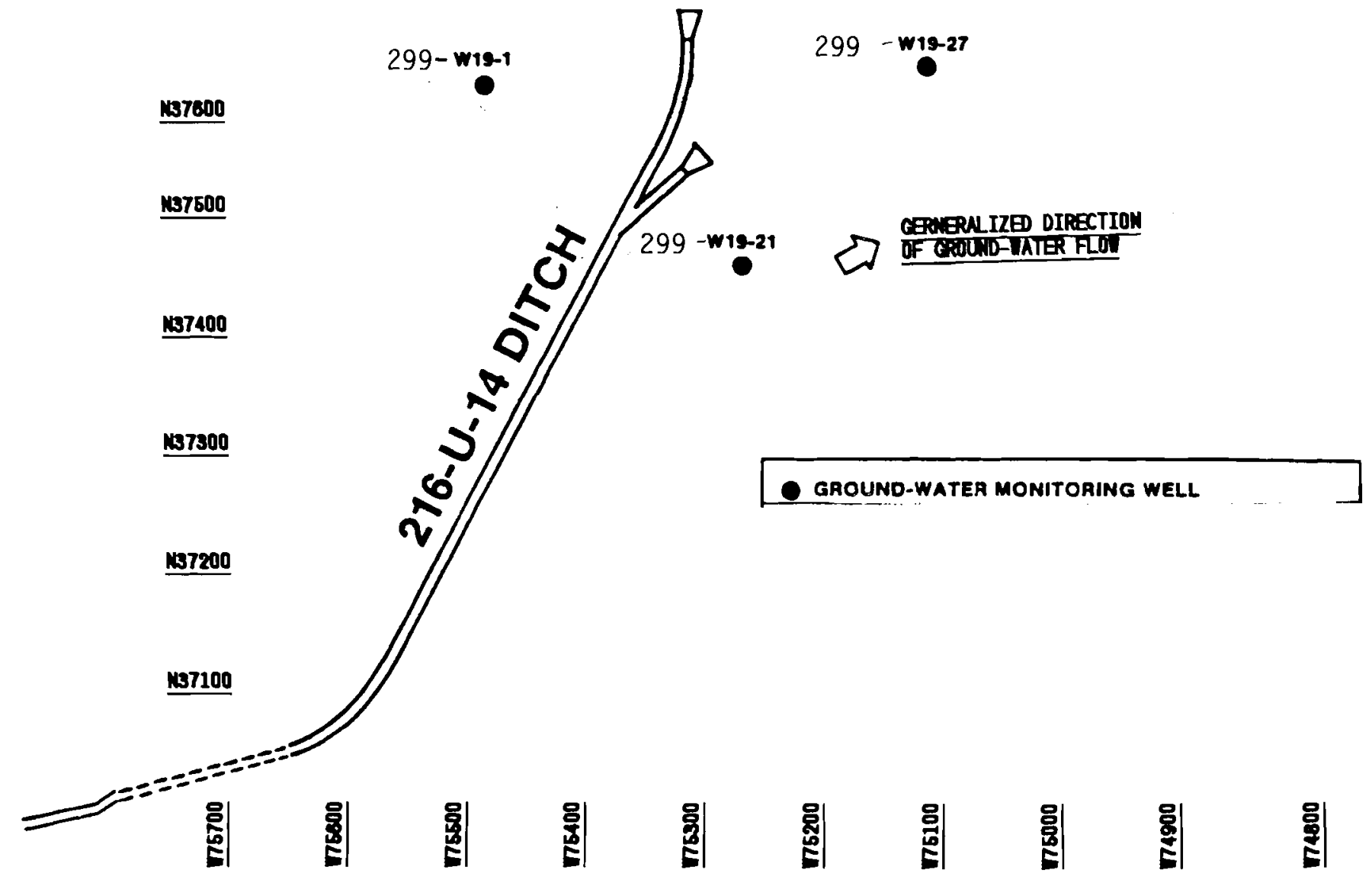

FIGURE B.16. Monitoring Well Locations at 216-U-14 Ditch

TABLE B.14. Sediment Column Leakage of Waste Components Disposed to 216-U-14 Ditch (216-U-14)

Monitoring

Wel1

299-W19-1

299-W19-21

$299-W 19-27$

299-W19-1

299-W19-21

299-W19-27

\section{Organics Identified in Groundwater}

None

None

None

Radionuclides Identified in Groundwater

Technetium-99

Cesium-137, pluton ium-239/40, ruthen ium-106

Ruthenium-106 
esmenacizso ountction of

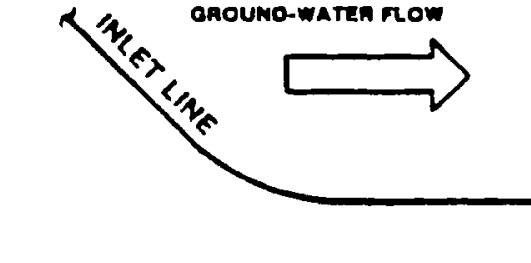

299- W19-23

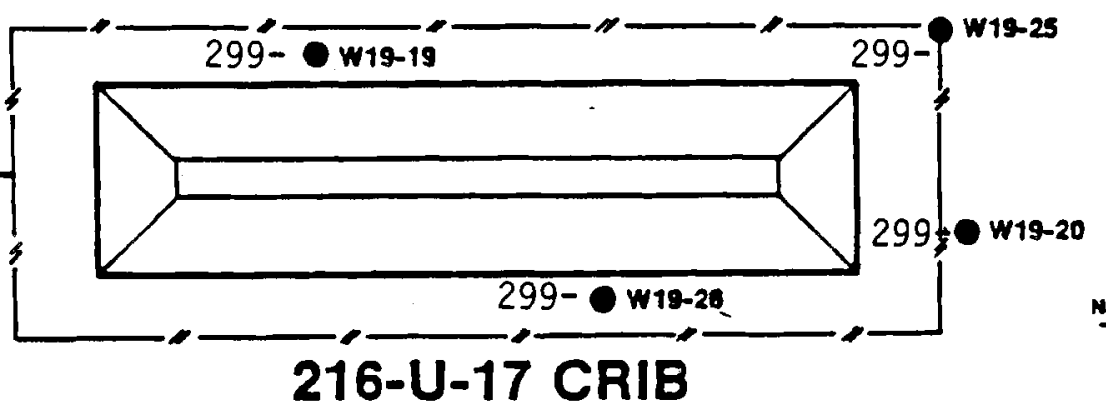

nassoo 216-U-17 CRIB

5

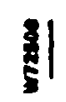

8

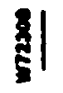

FIGURE B.17. Monitoring We11 Locations at 216-U-17 Crib 
TABLE B.15. Sediment Column Leakage of Waste Components Disposed to $216-\mathrm{U}-17 \mathrm{Crib}(216-\mathrm{U}-17)$

Monitoring

We 11

299-W19-19

299-W19-20

299-W19-23

299-W19-24

299-W19-25

299-W19-26

299-W19-19

$299-W 19-20$

$299-W 19-23$

$299-W 19-24$

$299-W 19-25$

$299-W 19-26$

\section{Organics Identified in Groundwater}

Radionuclides Identified in Groundwater

Cesium-137, cobalt-60, ruthenium-106, strontium-90, technetium-99, tritium

Cesium-137, cobalt-60, ruthenium-106, strontium-90, technetium-99, tritium

Cesium-137, plutonium-238, plutonium-239/40, ruthenium-106, technetium-99, tritium

Cobalt-60, plutonium-238, plutonium-239/40, ruthenium-106, strontium-90, technetium-99, tritium

Cesium-137, cobalt-60, plutonium-238, plutonium-239/40, ruthenium-106, technetium-99, tritium

Cesium-137, cobalt-60, technetium-99, tritium 


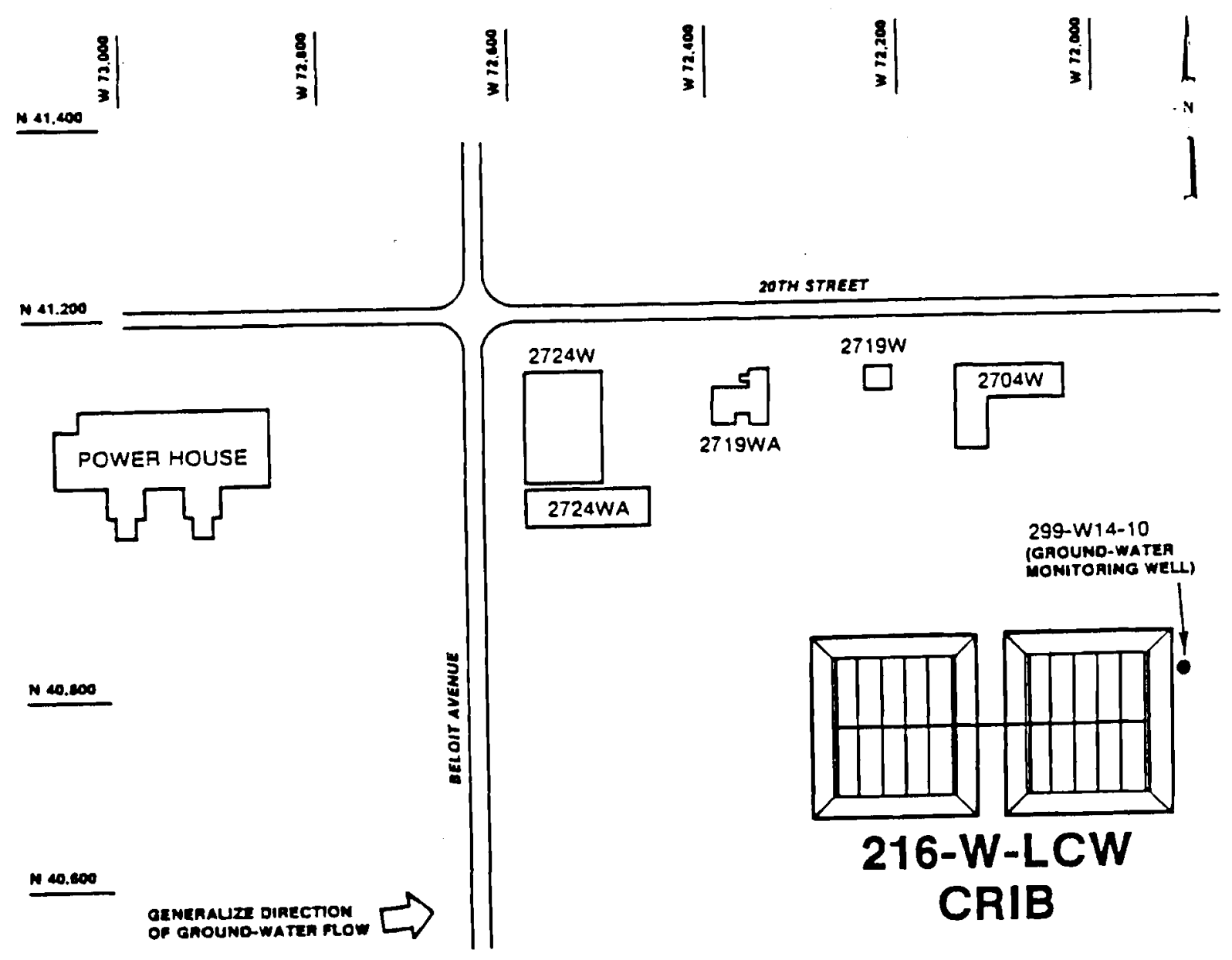

FIGURE B.18. Monitoring Well Location at 216-W-LCW Crib

TABLE B.16. Sediment column Leakage of Waste Components Disposed to $216-W-L C W$ Crib $(216-W-L C)$

Monitoring

Well

299-W14-10

Organics Identified in Groundwater

None

Radionuclides Identified in Groundwater

299-W14-10

Cesium-137, cobalt-60, ruthenium-106, strontium-90, tritium 

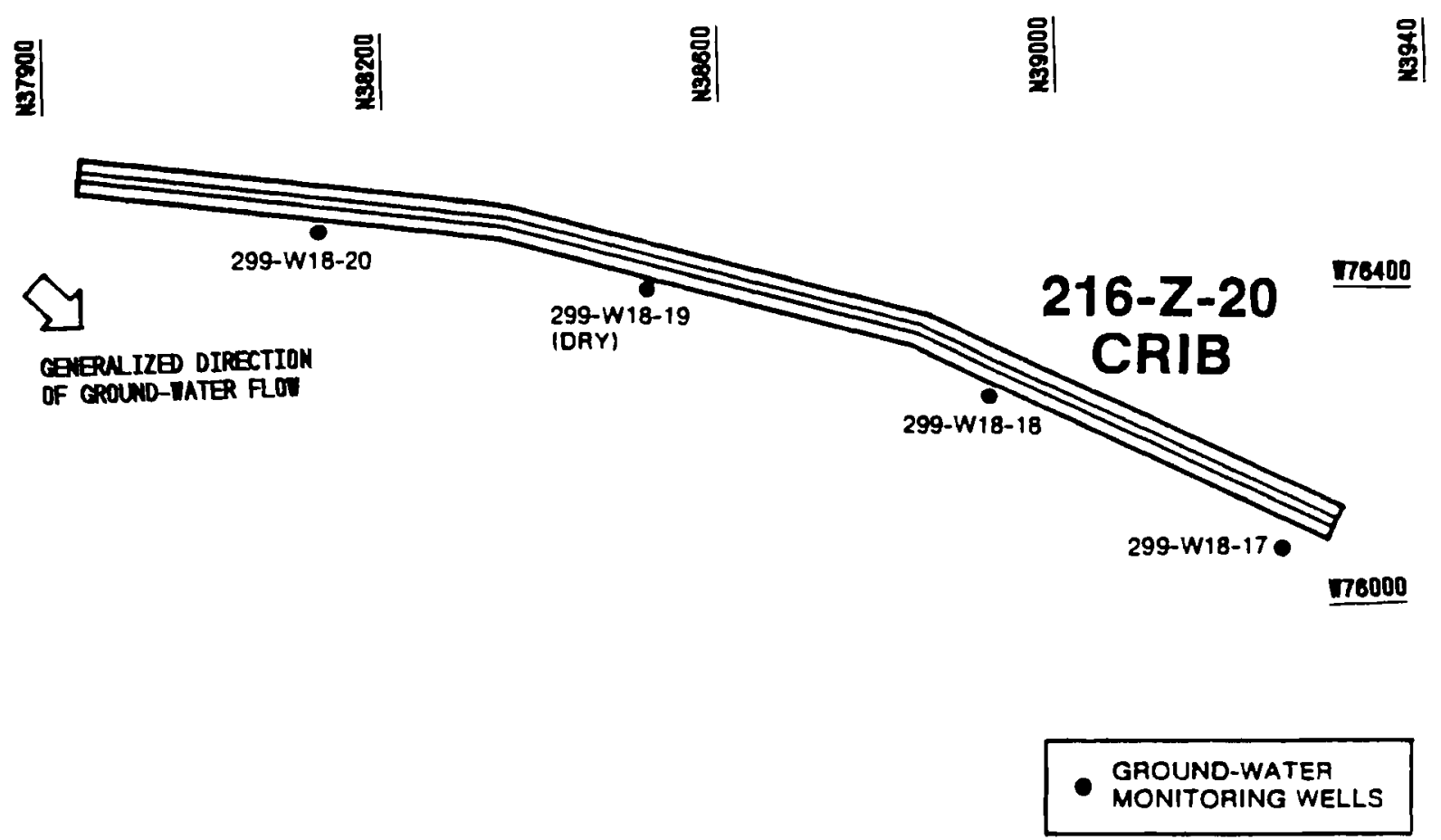

FIGURE B.19. Monitoring Well Locations at 216-Z-20 Crib

TABLE B.17. Sediment Column Leakage of Waste Components Disposed to $216-z-20$ Crib $(216-z-20)$

Monitoring Well

299-W18-17

$299-W 18-18$

299-W18-19

299-W18-20

299-W18-17

299-W18-18

299-W18-19

299-W18-20

\section{Organics Identified in Groundwater}

Acetone, carbon tetrachloride, TOX, chloroform

None

None

None

Radionuclides Identified in Groundwater

Cobalt-60, ruthenium-106, tritium

Cesium-137, cobalt-60, ruthenium-106, tritium

Cesium-137, cobalt-60, ruthenium-106, tritium

Cesium-137, cobalt-60, ruthenium-106, tritium 


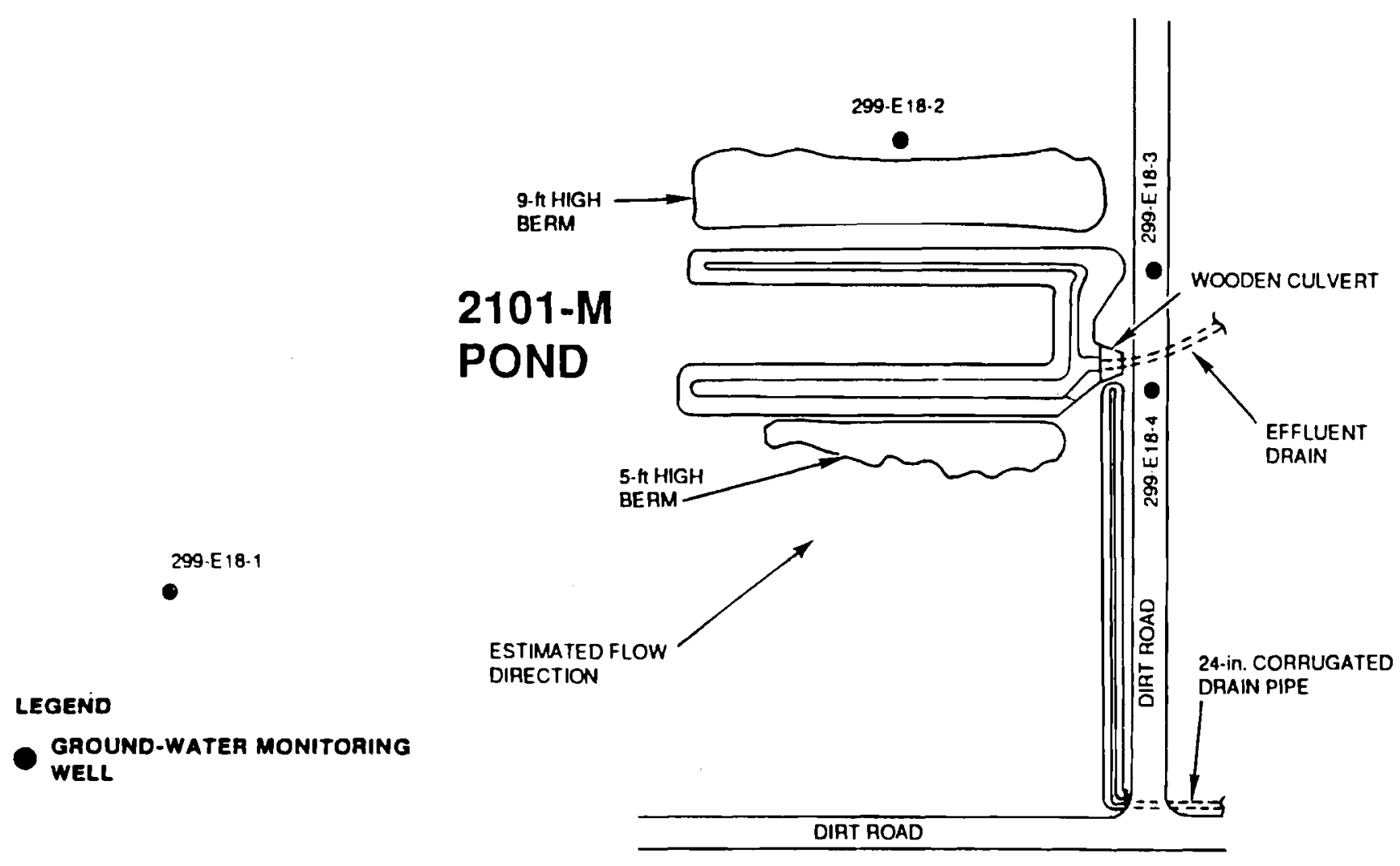

FIGURE B.20. Monitoring Well Locations at 2101-M Pond

TABLE B.18. Sediment Column Leakage of Waste Components Disposed to 2101-M Pond

Monitoring

$\frac{\text { Well } 1}{299-\text { E18-1 }}$

299-E18-2

299-E18-3

299-E18-4

Organics Identified in Groundwater

None

Acetone, TOX

TOX

TOX

Radionuclides Identified in Groundwater

299-E18-1

None

299-E18-2

None

299-E18-3

None

299-E18-4

None 


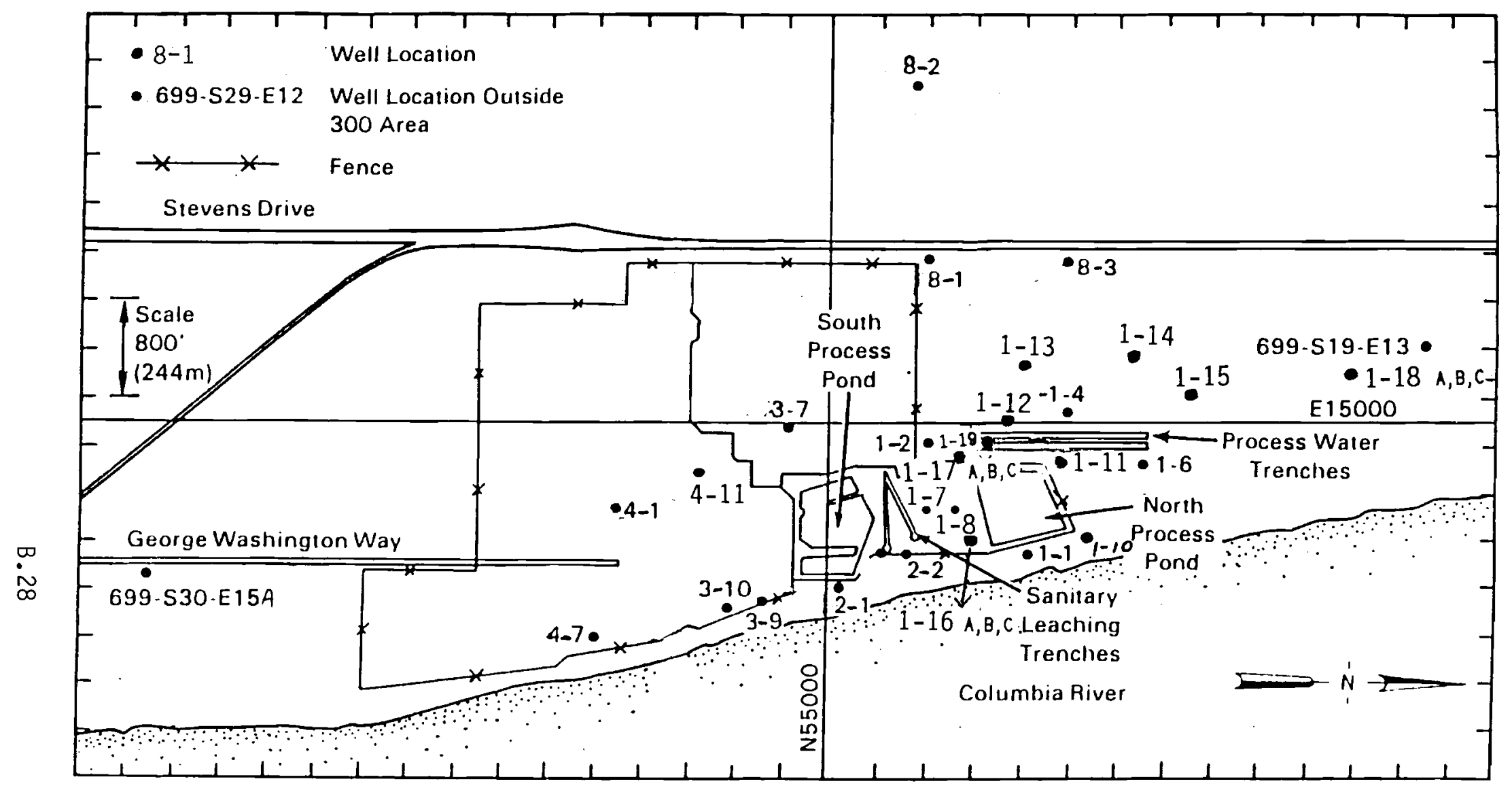

Note all wells $399-x-x$ or $399-x-x x$

FIGURE B.21. Monitoring Well Locations at the 300 Area Process Trenches 
TABLE B.19. Sediment Column Leakage of Waste Components Disposed to 300 Area Process Trenches (316-5)

\begin{tabular}{|c|c|}
\hline $\begin{array}{l}\text { Monitoring } \\
\text { Well }\end{array}$ & Organics Identified in Groundwater \\
\hline $399-1-1$ & Chloroform, methylene chloride, T0X \\
\hline $399-1-2$ & $\begin{array}{l}\text { Chloroform, hexane, methylene chloride, tetrachlorethane } \\
\text { TOX }\end{array}$ \\
\hline $399-1-4$ & Chloroform, methylene chloride, T0X \\
\hline $399-1-6$ & Chloroform, methylene chloride, thiourea, TOX \\
\hline $399-1-7$ & $\begin{array}{l}\text { Acetone, chloroform, methylene chloride, tetrachloro- } \\
\text { ethylene, tetraethylpyrophosphate, Tox }\end{array}$ \\
\hline $399-1-8$ & $\begin{array}{l}\text { 2,6-bis(1,1-dimethylethyl)-4-methyl phen, chloroform, } \\
\text { methylene chloride, phenol, TOX }\end{array}$ \\
\hline $399-1-10$ & $\begin{array}{l}\text { Chloroform, methylene chloride, 1,1,1-trichloroethane, } \\
\text { 1,2-dichloroethane, TOX }\end{array}$ \\
\hline $399-1-11$ & $\begin{array}{l}\text { Chloroform, 1,2-dichloroethane, methylene chloride, T0X, } \\
\text { 1,1,1-trichloroethane }\end{array}$ \\
\hline $399-1-12$ & Chloroform, TOX \\
\hline $399-1-13$ & Methyl ethyl ketone, TOX \\
\hline $399-1-14$ & Chloroform, methylene chloride, TOX \\
\hline $399-1-15$ & Acetone, chloroform, methylene chloride, TOX \\
\hline $399-1-16 A$ & Chloroform, methyl ethyl ketone, TOX \\
\hline $399-1-16 B$ & $\begin{array}{l}\text { Methyl ethyl ketone, TOX, trans-1,2-dichloroethene, } \\
\text { trichloroethylene }\end{array}$ \\
\hline $399-1-16 C$ & Trans-1,2-dichloroethene, trichloroethylene \\
\hline $399-1-17 A$ & $\begin{array}{l}\text { Chloroform, 1,1,1-trichloroethane, tetrachloroethylene, } \\
\text { TOX }\end{array}$ \\
\hline $399-1-17 B$ & Methylene chloride, trans-1,2-dichloroethene, TOX \\
\hline $399-1-17 C$ & TOX \\
\hline
\end{tabular}


TABLE B.19. (contd)

\begin{tabular}{|c|c|}
\hline $\begin{array}{l}\text { Monitoring } \\
\quad \text { We11 }\end{array}$ & Organics Identified in Groundwater \\
\hline $399-1-18 A$ & Carbon tetrachloride, methyl ethyl ketone \\
\hline $399-1-18 B$ & Methy 1 ethy 1 ketone \\
\hline $399-1-18 C$ & Methyl ethy 1 ketone \\
\hline $399-1-19$ & $\begin{array}{l}\text { Chloroform, tetrachloroethylene, trichloroethylene, } \\
1,1,1 \text {-trichloroethane, TOX }\end{array}$ \\
\hline $399-2-1$ & $\begin{array}{l}\text { Chloroform, methylene chloride, tetrachloroethylene, } \\
\text { tetrahydrofuran, TOX }\end{array}$ \\
\hline $399-2-2$ & Chloroform, methylene chloride, trichloroethylene, TOX \\
\hline $399-3-7$ & $\begin{array}{l}\text { Chloroform, methylene chloride, tetrachloroethylene, } \\
\text { 1,1,1-trichloroethane, T0x }\end{array}$ \\
\hline $399-3-9$ & Chloroform, TOX \\
\hline $399-3-10$ & $\begin{array}{l}\text { Bis(2-ethylhexyl)phthalate, chloroform, methylene } \\
\text { chloride, phenol, tetrachloroethylene, TOX }\end{array}$ \\
\hline $399-4-1$ & $\begin{array}{l}\text { Acetone, chloroform, 2-hexanone, phenol, TOX, } \\
\text { 1,12-trichloroethane, trichloroethylene }\end{array}$ \\
\hline $399-4-7$ & $\begin{array}{l}\text { 1,2-benzene dicarboxylic acid, chloroform, hexane, } \\
\text { methylene chloride, phenol, TOX }\end{array}$ \\
\hline $399-4-11$ & Chloroform, TOX, trichloroethylene \\
\hline $399-8-1$ & TOX \\
\hline $399-8-2$ & $\begin{array}{l}\text { Methylene chloride, phenol, tetrachloroethylene, TOX, } \\
\text { 1,1,1-trichloroethane }\end{array}$ \\
\hline $399-8-3$ & Chloroform, methylene chloride, TOX \\
\hline $699-\$ 19-E 13$ & $\begin{array}{l}\text { Chloroform, methylene chloride, tetrachloroethylene, TOX, } \\
\text { 1,1,1-trichloroethane }\end{array}$ \\
\hline \multirow[t]{2}{*}{$699-\$ 30-E 15 A$} & Methyl ethyl ketone, phenol, tetrahydrofuran, TOX \\
\hline & Radionuclides Identified in Groundwater \\
\hline $399-1-1$ & Cobalt-60, ruthenium-106, technetium-99, tritium \\
\hline $399-1-2$ & $\begin{array}{c}\text { Cobalt-60, ruthenium-106, technetium-99, tritium } \\
\text { B. } 30\end{array}$ \\
\hline
\end{tabular}


TABLE B.19. (contd)

Monitoring Well

399-1-4

399-1-6

399-1-7

399-1-8

399-1-10

399-1-11

399-1-12

399-1-13

399-1-14

399-1-15

399-1-16A

399-1-16B

399-1-16C

399-1-17A

399-1-17B

$399-1-17 \mathrm{C}$

399-1-18A

399-1-18B

399-1-18C

399-1-19

399-2-1

399-2-2

399-3-7

399-3-9
Radionuclides Identified in Groundwater

Cobalt-60, tritium

Cesium-137, cobalt-60, tritium

None

None

None

None

None

Tritium

Tritium

Tritium

Tritium

None

None

None

Cobalt-60, strontium-90

None

Tritium

Tritium

Tritium

None

Cobalt-60, technetium-99, tritium

Cobalt-60, strontium-90, ruthenium-106, technetium-99

Cesium-137, cobalt-60, tritium

Cobalt-60, strontium-90, technetium-99, tritium 
TABLE B.19. (contd)

Monitoring

Well

$399-3-10$

$399-4-1$

$399-4-7$

$399-4-11$

$399-8-1$

$399-8-2$

$399-8-3$

699-S19-E13

$699-S 30-E 15 A$
Radionuclides Identified in Groundwater

Cesium-137, cobalt-60, strontium-90, tritium

Cesium-137, cobalt-60, ruthenium-106, tritium

Cesium-137, cobalt-60, technetium-99, tritium

Tritium

Cesium-137, cobalt-60, ruthenium-106, tritium

Cobalt -60

Cesium-137, cobalt-60, ruthenium-106, tritium

Cesium-137, cobalt-60, ruthenium-106, tritium

Tritium 


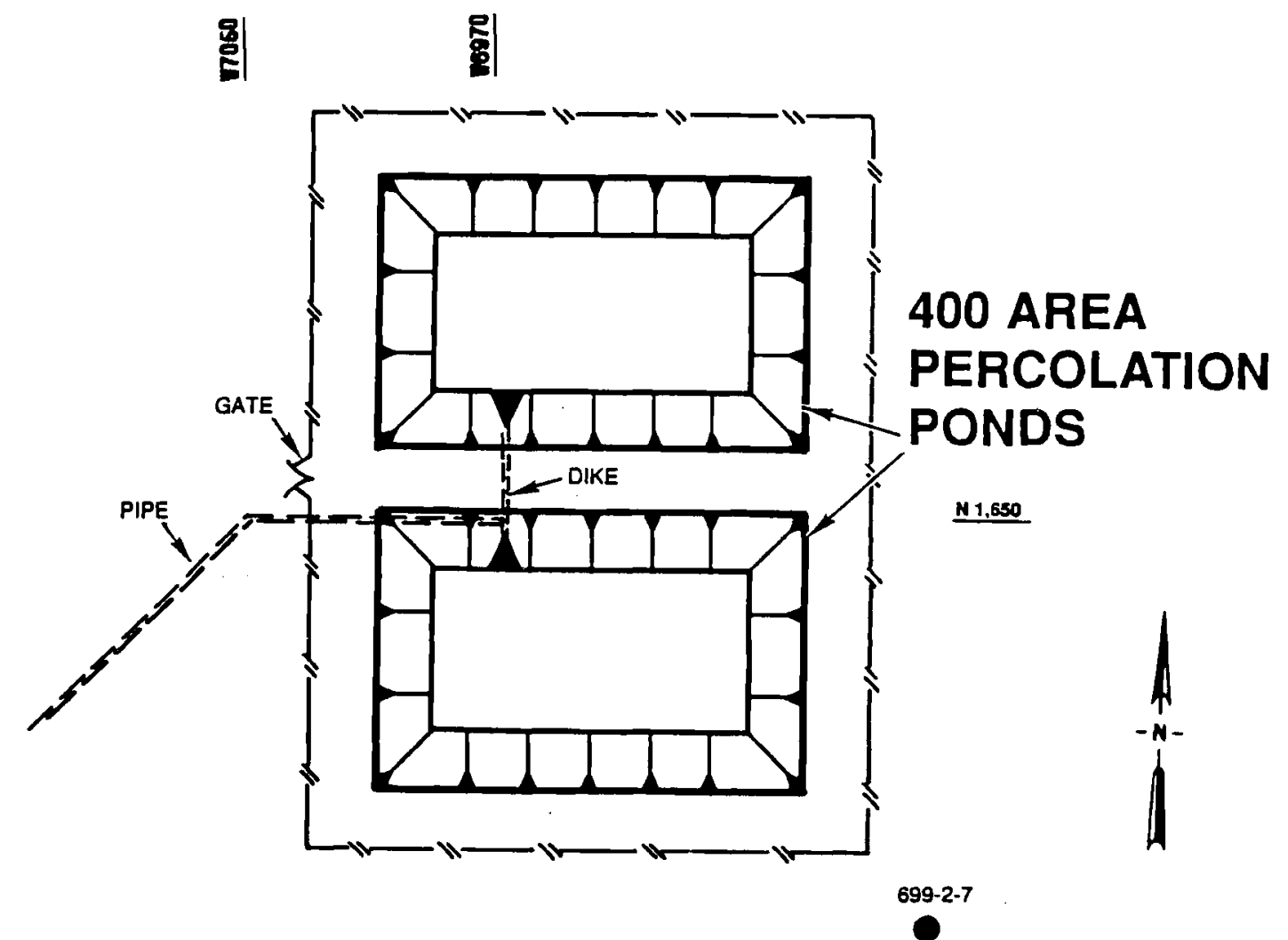

FIGURE B.22. Monitoring Well Location at 400 Area Percolation Ponds

TABLE B.20. Sediment Column Leakage of Waste Component Disposed to 400 Area Percolation Ponds (400 Area Process Pond and Sewer System)

Monitoring

$\frac{\text { Well }}{699-2-7}$

$699-2-7$ Organics Identified in Groundwater None

Radionuclides Identified in Groundwater Tritium 

PNL-7660

UC -512

\section{DISTRIBUTION}

No. of

Copies

\section{OFFSITE}

12 DOE/Office of Scientific and Technical information

5 U.S. Department of Energy 1000 Independence Ave. SW Forrestal Building Washington, DC 20585

ATTN: L. P. Duffy, EM-1

C. Frank, EM-50

S. Lien, EM-54

J. Lytle, EM-30

R. P. Whitfield, EM-40

3 DOE Office of Defense Waste

and Transportation Management

19901 Germantown Road

Germantown, MD 20545

ATTN: T. C. Chee, DP -123

K. A. Chacey, DP-123

T. B. Hindman, DP-12

C. R. Cooley, EM-55

U.S. Department of Energy

12800 Middle Brook Rd

Germantown, MD 20874

M. McFadden

DOE Albuquerque Operations Office

P. 0. Box 5400

Albuquerque, NM 87115

W. Brewer

Office of High-Level Nuclear Waste Management

Washington State Department of Ecology

Mail Stop PV-II

Olympia, WA 98504

3 Brookhaven National Laboratory

Upton, NY 11973

ATTN: M. Fuhrmann

R. F. Pietrzak

T. M. Sullivan
No. of

Copies

$5 \quad E G \& G$

P. 0. Box 1625

Idaho Falls, ID 83415

ATTN: R. G. Baca

S. Magnuson

J. McConnel

R. R. Seitz

J. B. Sisson

D. A. Lamar

Bovay Inc.

1200 Jadwin

Suite 204

Richland, WA 99352

3 Oak Ridge National Laboratory

P. 0. Box $X$

Oak Ridge, TN 37831

ATTN: T. M. Gilliam

H. W. Godbee

E. McDaniel

E. B. Peacock

Wastech, Inc.

P. 0. Box 1213

Oak Ridge, TN 37831-1213

J. M. Pope

West Valley Nuclear Services Co.

P. 0. Box 1910

West Valley, NY 14171

R. L. Treat

Ebasco Services

1201 Jadwin Ave

Suite 202

Richland, WA 99352

3 U.S. Nuclear Regulatory Commission Office of Nuclear

Regulatory Research

Washington, D.C. 20555

ATTN: T. C. Johnson

J. Surmeier

M. Silberberg 
No. of

Copies

3 Westinghouse Savannah River Company

Savannah River Site

Aiken, SC 29808-0001

ATTN: C. A. Langton

R. M. Wallace

E. Wilhite

\section{FOREIGN}

A. Atkinson

Atomic Energy Research

Establishment

HARWELL

Didcot

Oxfordshire, OX 11 ORA

UNITED KINGDOM

L. P. Buckley

Atomic Energy of Canada Ltd.

Chalk River, Ontario KOJ IJO

CANADA

R. Dayal

Ontario Hydro

800 Kipling Ave.

Toronto, Ontario M8Z 5S4

CANADA

\section{ONSITE}

4 DOE Richland Operations Office

E. A. Bracken

G. J. Bracken

C. Collantes

G. Rosenwald

3 Environmental Protection Agency

D. R. Sherwood, B5-01
No. of

Copies

30 Westinghouse Hanford Company

M. R. Adams, H4-54

H. Babad, H4-17

J. D. Berger, LO-18

L. C. Brown, H4-51

J. W. Cammann, H4-54

J. D. Davis, H4-54

C. Defigh-Price, H4-52

V. W. Hall, B2-15

R. Khaleel, H4-54

T. LeGore, B4-63

B. E. Opitz, R1-19

J. F. Relyea, H4-54

R. J. Roberts, R2-97

J. L. Scott, R2-87

J. C. Sonnichsen, H4-50

J. A. Voogd, B2-10

G. F. Williamson, R1-48

D. D. Wodrich, R2-23

R. D. Wojtasek, B2-15

D. E. Wood, B2-19

M. I. Wood, R2-87

47 Pacific Northwest Laboratory

L. L. Ames, P7-54

J. W. Buck, K6-96

L. J. Criscenti, K6-81

J. G. Droppo, K6-96

J. C. Evans, K6-81

J. W. Falco, K6-78

M. J. Fayer, K6-77

M. D. Fresh ley, K6-96

G. W. Gee, K6-77

L. K. Grove, K6-86

J. M. Hales, K6-04

P. C. Hays, K6-86

G. M. Holter, K6-28

C. J. Hostetler, K6-81

W. E. Kennedy, K3-54

C. T. Kincaid, K6-77

G. V. Last, K6-96

W. J. Martin, K6-81

W. T. Penne 11, K6-98

R. G. Riley, K6-81

L. E. Rogers, P7-54 
PNL-7660

UC-512

No. of

Copies

J. A. Schramke, K6-81

J. W. Shade, P8-37

R. J. Serne, K6-81

R. L. Skaggs, K6-77

R. M. Smith, K6-96

T. L. Stewart, K1-25

G. P. Streile, K6-77

J. H. Westsik, P7-44

R. E. Wildung, P7-54

Publishing Coordination

Technical Report Files 
